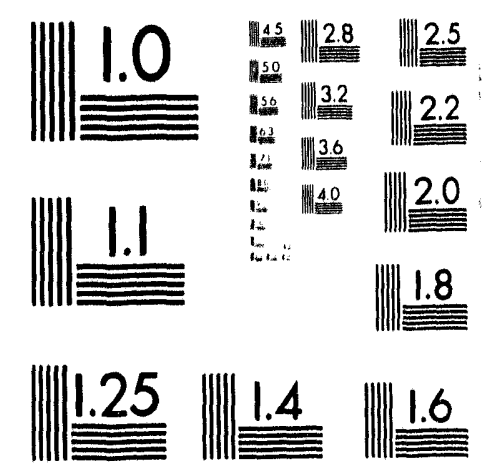




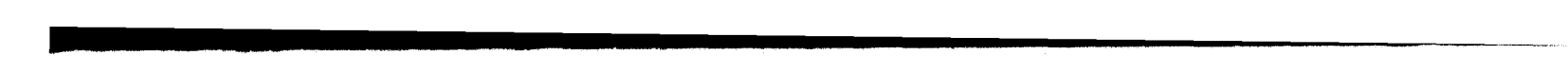

$\bullet$
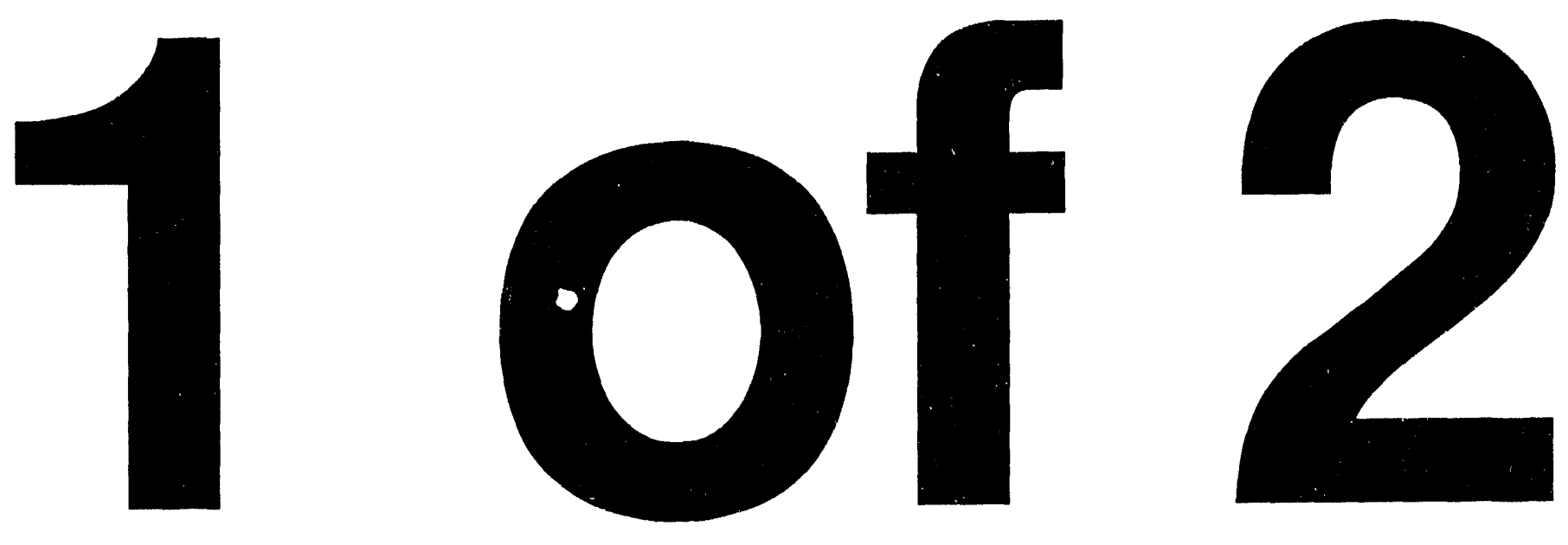


\title{
Full-Scale Retrieval of Simulated Buried Transuranic Waste
}

\author{
D. J. Valentich
}

Published September 1993

Caterpillar, Inc.

Defense and Federal Products 100 NE Adams Street

Peoria, Illinois 61629

Martin Marietta

Aero \& Naval Systems

103 Chesapeake Park Plaza

Baltimore, Maryland 21220

Prepared for the

U.S. Department of Energy

Office of Environmental Restoration and Waste Management

Under DOE Idaho Operations Office

Contract DE-AC07-76ID01570 


\section{Full-Scale Retrieval of Simulated Buried Transuranic Waste}

EGG-WTD-10895

Prepared by

ton J. Vatas

D. J. Valentich, Principal Investigator

Engincering

Reviewed by

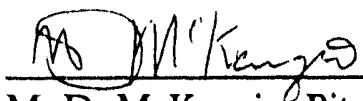

M. D. McKenzie, Pit 9 Program Staff

Environmental Restoration Technology Development

Approved by

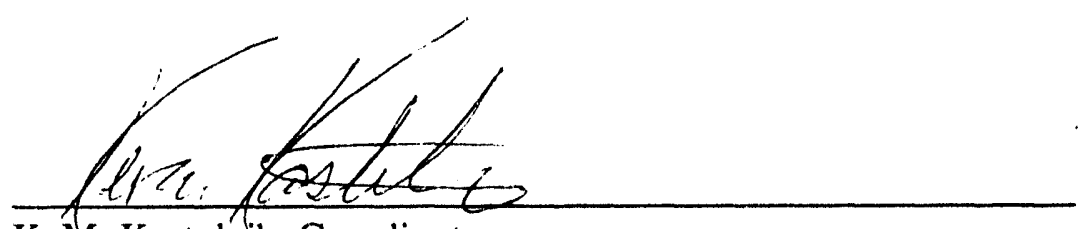

K. M. Kostelnik, Coordinator

Buried Waste Integrated Demonstration $\frac{8-30-93}{\text { Date }}$

$\frac{8-30-93}{\text { Date }}$

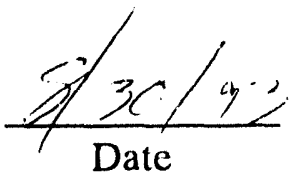




\begin{abstract}
This report describes the results of a field test conducted to determine the effectiveness of using conventional type construction equipment for the retrieval of buried transuranic (TRU) waste. A cold (nonhazardous and nonradioactive) test pit $\left(1,100 \mathrm{yd}^{3}\right.$ volume) was constructed with boxes and drums filled with simulated waste materials, such as metal, plastic, wood, concrete, and sludge. Large objects, including truck beds, tanks, vaults, pipes, and beams, were also placed in the pit. These materials were intended to simulate the type of wastes found in TRU buried waste pits and trenches. A series of commercially available equipment items, such as excavators and tracked loaders outfitted with different end effectors, were used to remove the simulated waste. Work was performed from both the abovegrade and belowgrade positions. During the demonstration, a number of observations, measurements, and analyses were performed to determine which equipment was the most effective in removing the waste. The retrieval rates for the various excavation techniques were recorded. The inherent dust control capabilitics of the excavation methods used were observed. The feasibility of teleoperating reading equipment was also addressed.
\end{abstract}




\section{SUMMARY}

A full-scale retrieval demonstration, sponsored by the U. S. Department of Energy's Office of Technology Development and coordinated by the Buried Waste Integrated Demonstration, was held in June 1993 at the Caterpillar, Inc. (CAT) Edwards Training Center (ETC) near Peoria, Illinois. The purpose of the demonstration was to determine the feasibility of using standard man-in-the-cab operated equipment for the retrieval of buried transuranic waste. Manually operated equipment and a highly skilled operator were chosen to define the best case for the use of construction type equipment in a waste retrieval scenario.

After a competitive bidding and review cycle a subcontract was awarded to CAT to build a cold test pit filled with simulated buried waste and retrieve the contents using conventional type construction equipment. CAT proposed that scveral different types of equipment and end effectors be tested in the field. These included a 325L excavator (referred to as $325 \mathrm{~L}$ ) with Balderson thumb end effector, 935C track loader (referred to as 935) with multipurpose bucket, EL200B excavator (referred to as EL200) with front shovel, and an IT28B integrated tool carrier with a grip and grab end effector (referred to as IT28 with grip and grab). These machines were selected from CAT's standard production models to maximize reliability during the test. Other support equipment included an IT28B integrated tool carrier for the transport of waste storage boxes from the cold test pit to the waste dumping area, and a 235B excavator outfitted with a pair of Allied-Gator shears (referred to as the shear) to be used for cutting and sizing large objects extracted from the pit.

Martin Marictta teamed with CAT to provide the test plan, video and photographic documentation of the test, and final report. Martin Marietta engineers videotaped the retrieval demonstration from waste material preparation, through pit construction and waste retrieval, to site cleanup and waste haulage. Additional video footage was taken from the two Martin Marietta-installed video cameras on the $325 \mathrm{~L}$.

The cold test pit was located on the ETC's Power Parade Site. The pit was situated on a broad gently sloping hillside. The entire work area was exposed dirt (i.e., there was no vegetation to be stripped away during construction of the pit or any other phase of the field demonstration). The cold test pit (overall size 7()$\times 32 \times 13 \mathrm{ft}$ ) was comprised of three separate cells, a stacked drums and boxes cell $(35 \times 32 \times 13 \mathrm{ft})$, an earth separation herm $(10 \times 32 \times 13 \mathrm{ft})$, and a random dumped drums and boxes cell $(25 \times 32 \times 13 \mathrm{ft})$. The stacked and random cells were filled with 55 -gal drums and $4 \times 4 \times 8$-ft boxes. The stacked cell contained a total of 220 drums (10\% metal and the rest cardboard) and 28 cardboard boxes. The random cell contained 330 drums (10\% metal and the remainder cardboard) and 25 cardboard boxes. Cardboard was selected because it deteriorates at an accelerated rate and more closely simulates the condition of actual buried waste containers. Each container was filled with a variety of debris of the type expected to be encountered in actual hot pits and trenches. Material included metal, wood, cloth, plastic, concrete, asphalt, paper, and simulated sludge. In addition to the filled containers, the random cell also contained large objects such as a tank, machine tool, beams, pipes, and cable. Work on the cold test pit started in late May 1993 and was completed by the first week in June 1993. The pit was excavated, the materials placed in each of the cells, and the areas covered with clean fill dirt and compacted. A soil separation berm was left in place between the random and stacked cell. 
Excavation of the pit occurred in four passes, each $8 \mathrm{ft}$ wide moving lengthwise along the pit. The first two passes were excavated from the belowgrade position and the last two from abovegrade. Various equipment combinations were tried at different times during the testing. The goal of the testing was to determine which piece of equipment worked most effectively from which position.

\section{Observed highlights of the field demonstration}

- The 325L excavator with Balderson thumb and EL200 excavator with reversed bucket performed equally well retrieving waste from belowgrade. However, overall the $325 \mathrm{~L}$ with thumb proved to be the more versatile machine. The $325 \mathrm{~L}$ was consistently able to remove all varieties of simulated waste forms and large objects from belowgrade. The average volume of material removed by these excavators was just under $50 \mathrm{yd}^{3} /$ hour, or nearly $400 \mathrm{yd}^{3} /$ day ( 8 -hour shift). This far exceeded the stated objective of $80 \mathrm{yd}^{3} /$ day.

- Dust generation was minimal, however, the soil was fairly moist during most of the demonstration. Operation of the Balderson thumb was done in a careful and deliberate manner to ensure that regardless of soil conditions, the agitation of dust would be minimal.

- Spillage of soil and debris by the $325 \mathrm{~L}$ was virtually nonexistent. For the purposes of the field demonstration, spillage was considered to be any material that dropped from the end effector once the load had been picked up at the digface, swung to the funnel, and dumped into the transport box. Less than $1 \mathrm{yd}^{3}$ of material was spilled during the entire operation, and most of this was during the dumping operation from the thumb into the funnel and transport box. Any debris that was spilled was picked up by the thumb and bucket and placed in the transport box.

- The 325L excavator with Balderson thumb demonstrated a high degree of dexterity. It was capable of picking over $1 \mathrm{yd}^{3}$ loads of heterogeneous waste with no spillage and then selectively plucking 1 in. diameter cable from the debris and "folding" $50 \mathrm{ft}$ lengths of the cable into segments short enough to be picked up and placed in the transport box. The thumb handled large objects well, including a storage tank, 6-ft metal cube and machine tool. When necessary, combined use of the thumb and bucket provided delicate operation, such as picking up an intact drum and transporting it from the digface to the funnel without damage.

- Operation of the $325 \mathrm{~L}$ from the abovegrade and belowgrade positions was not significantly different in terms of production when working in heterogeneous waste (not including large objects). However, the belowgrade position was preferred because operator visibility is enhanced, there is less risk of digface collapse and ease with which large objects can be removed. It was obvious from the field testing that work could be performed from either position.

- Although the average production rate was determined to be nearly $400 \mathrm{yd}^{3} /$ day $(8$-hour day), it is recognized that this rate would be diminished by using a remotely operated system. As a rough first estimate (without the benefit of field testing), it is postulated that production would be cut by half. The $200 \mathrm{yd}^{3} /$ day projected for remote operation has a considerable margin over the original goal of $80 \mathrm{yd}^{3} / \mathrm{day}$. Planned follow on work during 
fiscal year 1994 will involve a remote retricval demonstration and will further define the expected production capability.

- Iriformation gathered by Martin Marictta during the field demonstration on the use of 2-D and 3-D camera systems will be helpful in the design of remote operated systems.

- The technology to remotize the 325L to work in a contaminated environment is currently available. A rough order of magnitude cost to remotize a $325 \mathrm{~L}$ is $\$ 1,000 \mathrm{~K}$. This price is only for the remote control system and does not include machine price, hardening of the excavator for operation in a contaminated environment, or other related costs.

- The demonstration was performed in a safe and environmentally responsible manner with no injuries, damaged equipment, or threat to the environment.

At the conclusion of the excavation, the simulated debris was loaded and hauled to an approved landfill for permanent disposal. The cold test pit was reclaimed with clean fill material, compacted, and graded to the original contours of the surrounding area.

In summary, it has been shown that the retricval of buried waste can be accomplished with standard type equipment. This equipment will ultimately require modification to work in a contaminated environment, but the technology to accomplish this is available now. Through an aggressive testing and demonstration program, a family of remotely operated equipment can be developed during the next several years that will be suitable for the retrieval of buried waste. 


\section{ACKNOWLEDGEMENTS}

Thanks is given to the engineers of Martin Marictta who wrote the majority of this document. Mr. Brian D. McFeeters of Caterpillar, Inc. also assisted with the writing of this final report. 


\section{CONTENTS}

ABSTRACT $\ldots \ldots \ldots \ldots \ldots \ldots \ldots \ldots \ldots \ldots \ldots \ldots \ldots \ldots \ldots \ldots \ldots \ldots$ iii

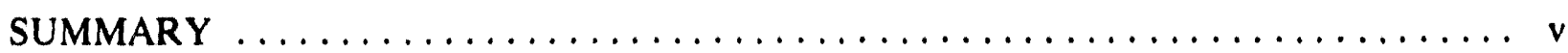

ACKNOWLEDGEMENTS $\ldots \ldots \ldots \ldots \ldots \ldots \ldots \ldots \ldots \ldots \ldots \ldots$ ix

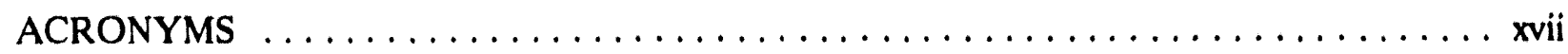

1. INTRODUCTION $\ldots \ldots \ldots \ldots \ldots \ldots \ldots \ldots \ldots \ldots \ldots \ldots \ldots \ldots \ldots \ldots \ldots \ldots$. 1

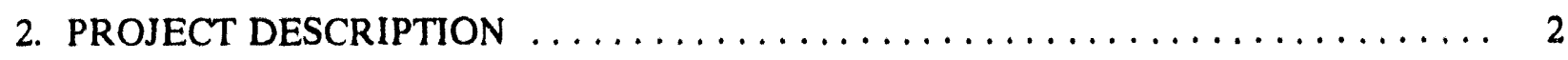

2.1 Background Information $\ldots \ldots \ldots \ldots \ldots \ldots \ldots \ldots \ldots \ldots \ldots \ldots \ldots \ldots \ldots \ldots \ldots \ldots \ldots \ldots, 2$

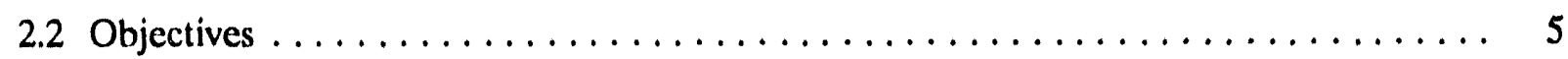

3. PROJECT ORGANIZATION $\ldots \ldots \ldots \ldots \ldots \ldots \ldots \ldots \ldots \ldots \ldots \ldots \ldots \ldots$

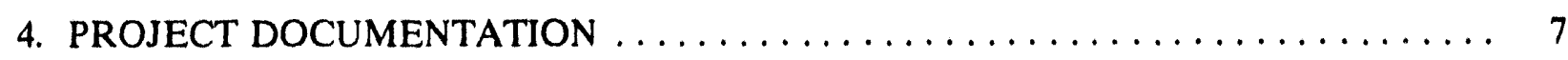

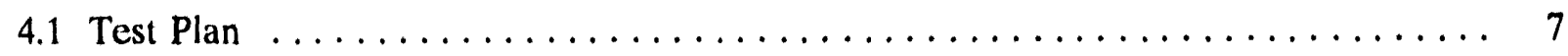

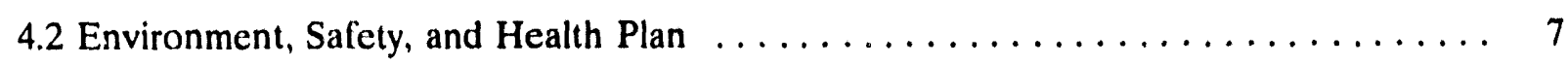

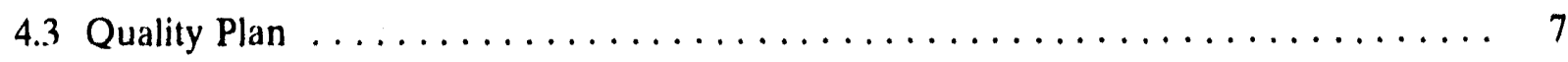

4.4 Project Management Plan $\ldots \ldots \ldots \ldots \ldots \ldots \ldots \ldots \ldots \ldots \ldots \ldots \ldots \ldots$

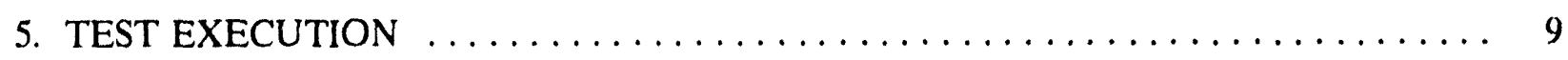

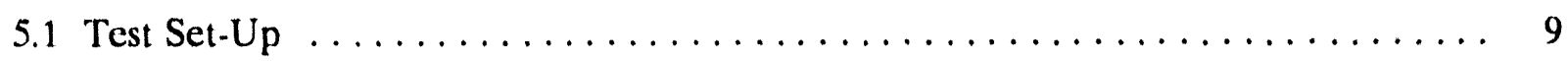

5.1 .1 Construction of Cold Test Pit $\ldots \ldots \ldots \ldots \ldots \ldots \ldots \ldots \ldots \ldots, \ldots$

5.1 .2 Overview of Retrieval $\ldots \ldots \ldots \ldots \ldots \ldots \ldots \ldots \ldots \ldots \ldots \ldots \ldots$

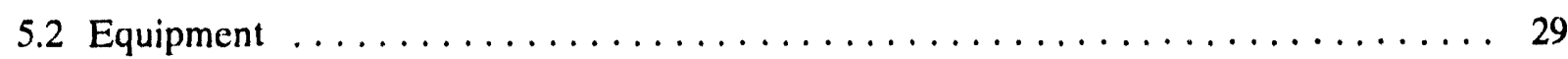

5.3 Excavation, Sizing, Handling, and Dumping of Simulated Waste $\ldots \ldots \ldots \ldots \ldots 30$

5.3.1 Commentary on Excavation, Handling, and Dumping of Waste $\ldots \ldots \ldots \ldots .53$

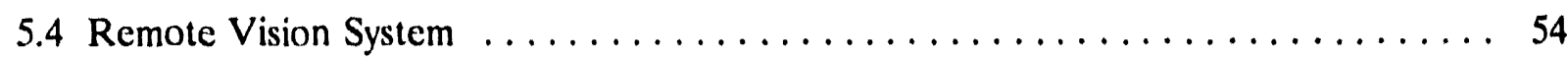

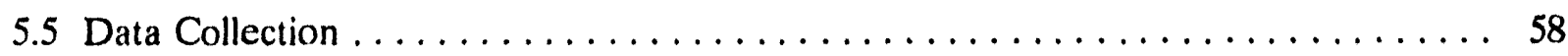


5.6 Disposal of Buried Waste and Site Reclamation $\ldots \ldots \ldots \ldots \ldots \ldots \ldots$

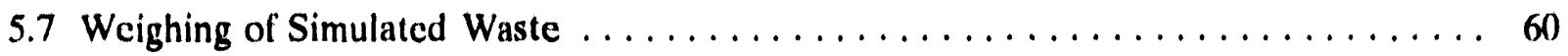

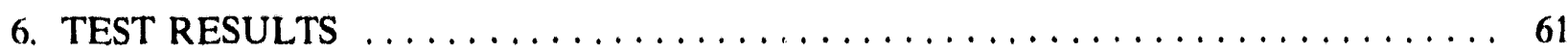

6.1 Effectiveness of Selected Equipment $\ldots \ldots \ldots \ldots \ldots \ldots \ldots \ldots \ldots \ldots \ldots \ldots$

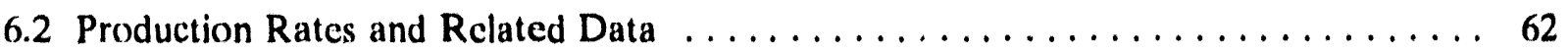

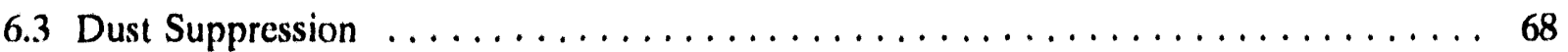

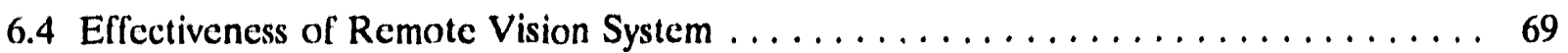

7. REMOTIZING EQUIPMENT $\ldots \ldots \ldots \ldots \ldots \ldots \ldots \ldots \ldots \ldots \ldots \ldots \ldots \ldots$ 70

7.1 Remotizing Equipment Used for the Retrieval Demonstration $\ldots \ldots \ldots \ldots \ldots$

7.2 ROM Costs for Remotizing Equipment $\ldots \ldots \ldots \ldots \ldots \ldots \ldots \ldots \ldots \ldots$

8. LESSONS LEARNED $\ldots \ldots \ldots \ldots \ldots \ldots \ldots \ldots \ldots \ldots \ldots \ldots \ldots \ldots \ldots \ldots$

9. RECOMMENDATIONS AND CONCLUSIONS $\ldots \ldots \ldots \ldots \ldots \ldots \ldots \ldots \ldots$

9.1 Feasibility of Using Conventional Equipment $\ldots \ldots \ldots \ldots \ldots \ldots \ldots \ldots \ldots$

9.2 Abovegrade Versus Belowgrade $\ldots \ldots \ldots \ldots \ldots \ldots \ldots \ldots \ldots \ldots \ldots \ldots$

9.3 Probable Retrieval Rate $\ldots \ldots \ldots \ldots \ldots \ldots \ldots \ldots \ldots \ldots \ldots \ldots \ldots \ldots \ldots$

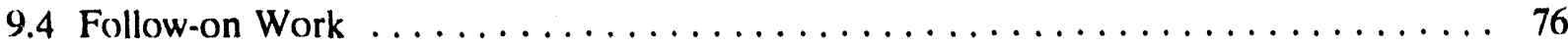

9.5 Contamination Control Observations $\ldots \ldots \ldots \ldots \ldots \ldots \ldots \ldots \ldots \ldots \ldots$

9.6 Remotization Feasibility $\ldots \ldots \ldots \ldots \ldots \ldots \ldots \ldots \ldots \ldots \ldots \ldots \ldots \ldots$

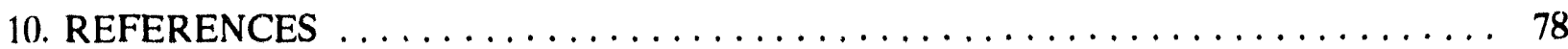

Appendix A-Cold Test Pit Requirements Verification Matrix $\ldots \ldots \ldots \ldots \ldots \ldots \ldots$

Appendix B-Equipment Production Matrix $\ldots \ldots \ldots \ldots \ldots \ldots \ldots \ldots \ldots \ldots \ldots \ldots$

\section{FIGURES}

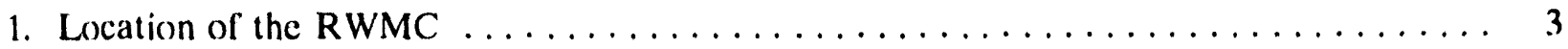

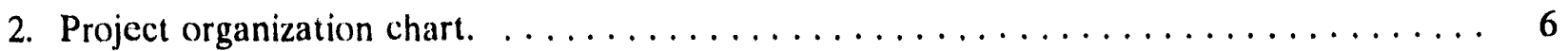




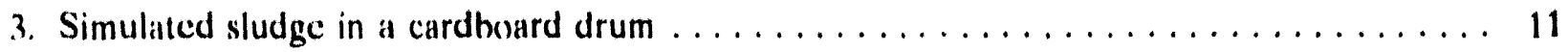

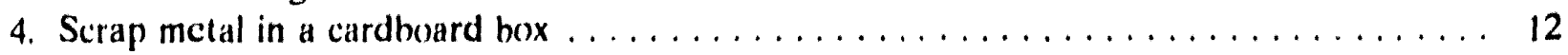

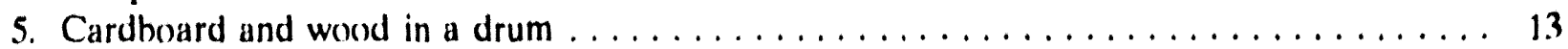

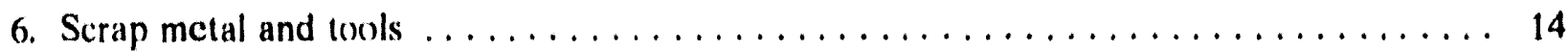

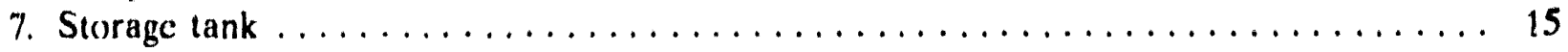

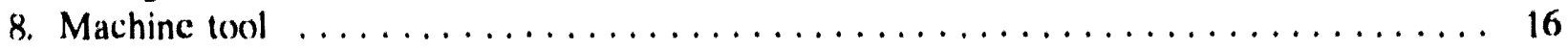

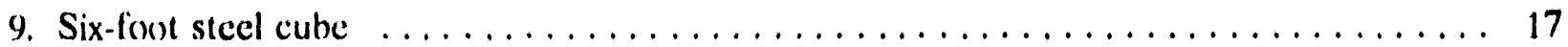

10. Mixing simulated sludge in $\operatorname{mortar} \operatorname{mixer} \ldots \ldots \ldots \ldots \ldots \ldots \ldots \ldots \ldots \ldots \ldots$

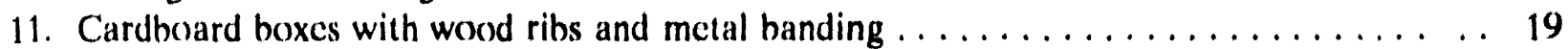

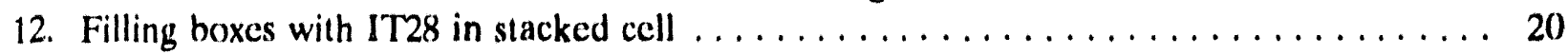

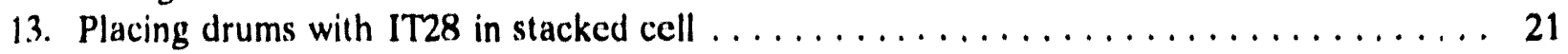

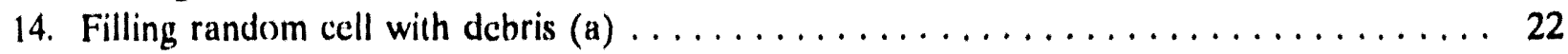

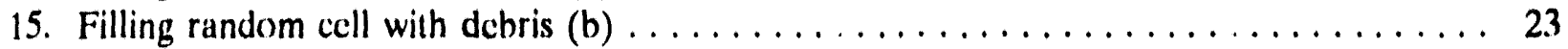

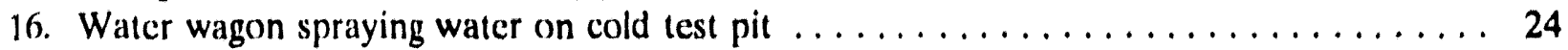

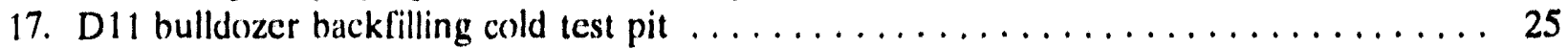

18. Excavation of cold test pit occurred in four passes $\ldots \ldots \ldots \ldots \ldots \ldots \ldots \ldots \ldots$

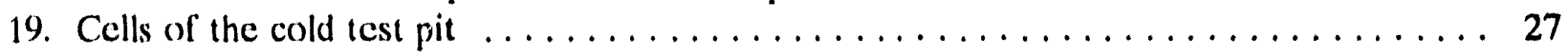

20. Exposed face of cold test pit before start of excavation $\ldots \ldots \ldots \ldots \ldots \ldots \ldots \ldots \ldots \ldots$

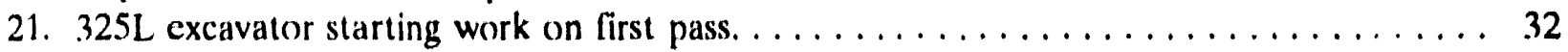

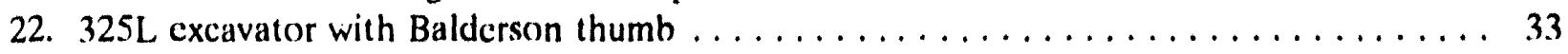

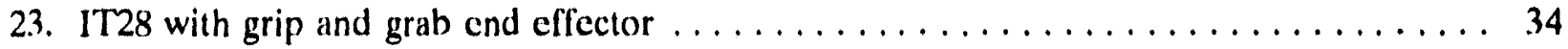

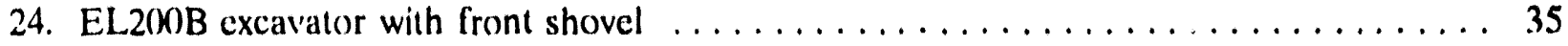

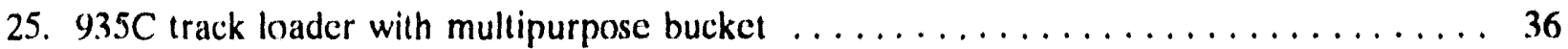

26. $235 \mathrm{~B}$ excavator with Allied-Gator hydraulic shears $\ldots \ldots \ldots \ldots \ldots \ldots \ldots \ldots \ldots \ldots$

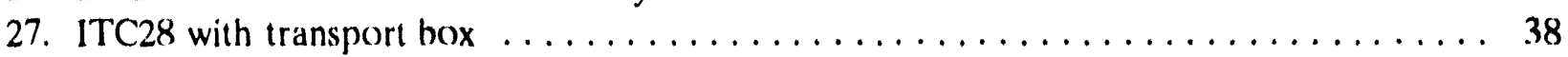

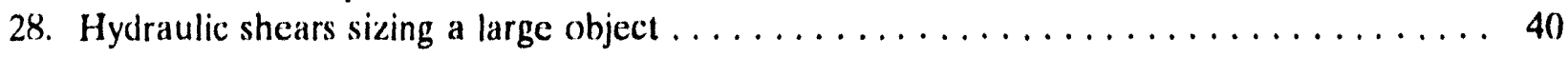

29. Balderson thumb handling small objects and cable $\ldots \ldots \ldots \ldots \ldots \ldots \ldots \ldots \ldots \ldots$

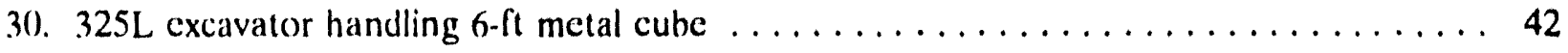

31. Banding and debris dangling from bucket $\ldots \ldots \ldots \ldots \ldots \ldots \ldots \ldots \ldots \ldots \ldots \ldots$

32. ITC with grip and grab end effector at digface $\ldots \ldots \ldots \ldots \ldots \ldots \ldots \ldots \ldots$

33. $935 \mathrm{C}$ track loader working at the digface $\ldots \ldots \ldots \ldots \ldots \ldots \ldots \ldots \ldots \ldots \ldots$

34. EL20OB with front end shovel excavating debris from the digface $\ldots \ldots \ldots \ldots \ldots \ldots$

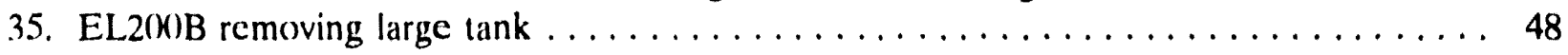

36. Hydraulic shear sizing a large storage tank $\ldots \ldots \ldots \ldots \ldots \ldots \ldots \ldots \ldots \ldots \ldots$

37. 325L working from abovegrade position $\ldots \ldots \ldots \ldots \ldots \ldots \ldots \ldots \ldots \ldots \ldots \ldots$

38. Luading excavated debris for transport to approved landfill $\ldots \ldots \ldots \ldots \ldots \ldots \ldots \ldots$. $\ldots \ldots$

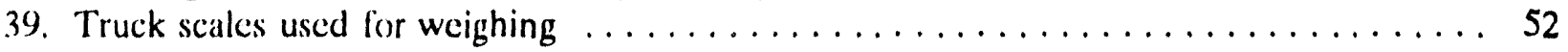

40. Containers breached to create a heterogeneous mix of waste $\ldots \ldots \ldots \ldots \ldots \ldots \ldots$

41. Funnel was effective to focus waste into transport box. $\ldots \ldots \ldots \ldots \ldots \ldots \ldots \ldots \ldots$

42. Sample of data collection sheet $\ldots \ldots \ldots \ldots \ldots \ldots \ldots \ldots \ldots \ldots \ldots \ldots \ldots \ldots$

43. Comparison of cycle times for various equipment $\ldots \ldots \ldots \ldots \ldots \ldots \ldots \ldots \ldots \ldots$

44. 325L excavator efficiency working from abovegrade and belowgrade $\ldots \ldots \ldots \ldots \ldots 6$

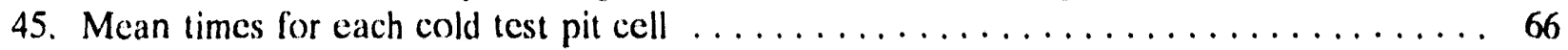

46. Comparison of percent utilization of different end effectors $\ldots \ldots \ldots \ldots \ldots \ldots \ldots \ldots$ 


\section{TABLES}

1. Brief chronological history of cold test pit construction $\ldots \ldots \ldots \ldots \ldots \ldots \ldots \ldots \ldots$

2. Primary equipment used for retrieval demonstration $\ldots \ldots \ldots \ldots \ldots \ldots \ldots \ldots \ldots$

3. Equipment used during excavation of cold test pit $\ldots \ldots \ldots \ldots \ldots \ldots \ldots \ldots \ldots \ldots$

4. Equipment effectiveness shows the $325 \mathrm{~L}$ and EL200 to be equally effective in

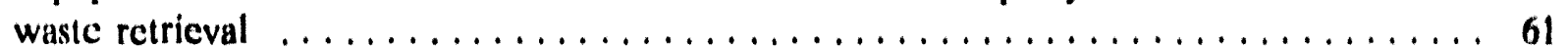

5. Average daily rate during retrieval far excecded the $80 \mathrm{yd}^{3} /$ day goal $\ldots \ldots \ldots \ldots \ldots . . \ldots 6$ 


\section{ACRONYMS}

BWID Buried Waste Integrated Demonstration

CAT Calcrpillar, Inc.

DOE $\quad$ U. S. Department of Energy

DOE.ID U. S. Department of Energy Idaho Operations Office

ES\&H Environmental, Safely, and Health Plan

HTC Edwards Training Center

FY

Fincal yeur

INIL. IJaho National Engineering Laboratory

I.I.W Low.level waste

OTD Office of Technology Development

PMP Project Management Plan

RIP Rocky Flats Plant

ROM Rough order of magnitude

RWMC Radioactive Waste Management Complex

SDA Subsurface Disposal Area

TRU Transuranic 


\section{Full-Scale Retrieval of Simulated Buried Transuranic Waste}

\section{INTRODUCTION}

This report presents a detailed account of a full-scale retrieval demonstration performed to determine the feasibility of using conventional equipment for the removal of buried transuranic (TRU) waste. Initially, the report provides background information about the history of buried waste in the U. S. Department of Energy (DOE) complex. DOE's efforts to remove the waste and remediate the envircnment are also examined. Next, the purpose and goals of the full-scale retrieval demonstration are described, and details of the planned test and field execution are provided. Results are then analyzed, and the document concludes with sections dealing with lessons learned and recommendations for future work. 


\section{PROJECT DESCRIPTION}

\subsection{Background Information}

DOE and its predecessor agencies have operated numerous facilities throughout the United States for research, development, and production of defense materials and nuclear energy. Waste generated as a result of these and other operations has been buried in the ground or stored for future disposal at locations throughout the DOE complex. One of these sites, the Subsurface Disposal Area (SDA) is located at the Idaho National Engineering Laboratory (INEL) in the Radioactive Waste Management Complex (RWMC) (see Figure 1). The RWMC comprises about 144 acres, of which 88 are the SDA. The SDA was opened in 1952 for the disposal of solid low-level waste (LLW) generated by the operations at the INEL.

In 1954, per direction of the Atomic Energy Commission, disposal of TRU waste began at the SDA. The majority of TRU waste was generated from the Rocky Flats Plant (RFP) in Colorado. In 1970, the disposal of TRU contaminated waste in the SDA was discontinued. Since 1970, the waste has been placed in protected and monitored aboveground storage at the RWMC, where it will remain until a suitable permanent disposal method is available. Before 1970, waste disposal at the SDA consisted of random dumping and orderly placement of containers in pits and trenches. A variety of large contaminated items including cranes, tanks, vaults, and bulky equipment were also buried. The total volume of buried TRU waste is approximately 2 million $\mathrm{ft}^{3}$. It is intermixed with about 1 million $\mathrm{ft}^{3}$ of LLW and 5 million $\mathrm{ft}^{3}$ of soil resulting in a total waste volume of 8 million $\mathrm{ft}^{3}$. The TRU waste received from RFP also contains hazardous waste, as defined by current Environmental Protection Agency regulations, resulting in radioactive mixed waste. Much of the waste contained within the SDA is representative of the type found at other DOE buried waste sites. About $30 \%$ of the DOE complex's buried waste is stored at the INEL.

Most of the waste buried at the SDA (and throughout the DOE complex) was initially stored in metal barrels, boxes, or other similar containers. Over time these containers have deteriorated and many have breached, contaminating the surrounding soil and posing a threat to local groundwater. It is the intent of DOE to remediate the SDA by restoring the area to a condition that is not a threat to people or the environment. This remediation will consist of characterization, monitoring, retrieval, treatment, and final disposal of the waste.

As a part of DOE's commitment to remediating buried waste sites, the Office of Technology Development (OTD) was established. OTD's primary mission is to develop and demonstrate advanced remediation technologies that support DOE's environmental restoration objectives. Proven technologies do not exist for the in situ treatment, removal, and treatment after exhumation of buried waste. To address these issues and identify other technological deficiencies, OTD has initiated the Buried Waste Integrated Demonstration (BWID) at the INEL. BWID is coordinated for the DOE by EG\&G Idaho, Inc., at the INEL; however, the program involves engineers and other professionals with scientific expertise from throughout the DOE complex, universities, and private sector. BWID will address the complex problems associated with buried waste by initially focusing on buried waste located at the INEL. Technologies that are successfully developed within the BWID will result in transfer of scientifically sound, demonstrated technologies that can be deployed in various Environmental Restoration Programs throughout the DOE complex. 


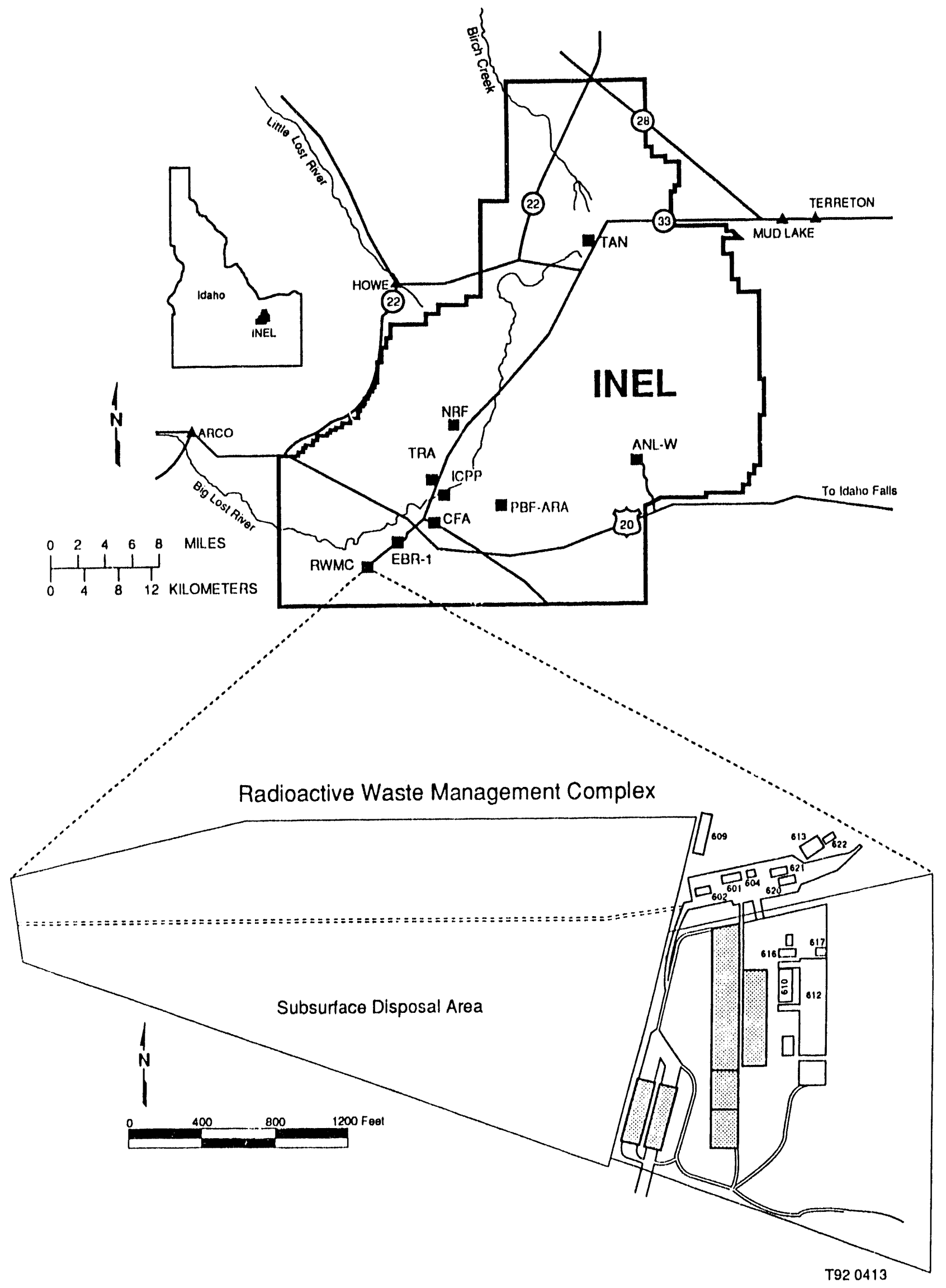

Figure 1. Location of the RWMC. 
One of the technologies being considered for the retrieval of buried waste is the use of conventional construction equipment to excavate and remove debris and soil from the pits and trenches. Although an obvious potential means for the removal of buried waste, prior to the retrieval demonstration, no significant testing had been performed to determine if the use of equipment such as excavators and loaders was technically feasible for retrieval. Therefore, it was decided by BWID that a demonstration to evaluate the effectiveness of man-in-the-cab operated equipment for the retrieval of huried waste would be an appropriate first step in determining the feasibility of this technology to help remediate DOE buried waste sites.

A subcontract was awarded to Caterpillar, Inc. to provide a simulate 'cold test pit and various equipment and end effectors to remove the waste and soil. The cold test pit was constructed at Caterpillar, Inc., (CAT) Edwards Training Center (ETC) located near Peoria, Illinois. During June 1993. a series of tests using a variety of CAT manufactured equipment were conducted at the ETC.

The retrieval demonstration was intended to be the first step in verifying that commercial equipment can be used for retrieval purposes. The initial phase of work focused on a simple configuration targeted at the mechanics of removing, handling, and sizing buried waste. An actual retrieval effort in a hot environment involving conventional type equipment would require remote operation, would be performed in a suitably contained structure, would be worked in conjunction with a contamination control system, and equipment would need to be properly hardened to function in a contaminated environment. It is planned that outyear testing address all of these issues.

The first step in this process was to evaluate if conventional equipment can effectively remove buried waste. This included the excavation and retrieval of $4 \times 4 \times 8$ - $\mathrm{ft}$ storage boxes and 55-gal drums filled with debris such as metal, tools, cloth and clothing, glass, plastics, concrete, wood, asphalt, wire, other building materials, and sludge/grease mixtures. In many cases, the containers are breached, and the materials were mixed with soil. Another major concern in the buried waste pits and trenches is the removal of large objects, including glove boxes, vehicles, tanks, vessels, pipes, beams, cable, and machinery. Large objects intended to simulate these materials were also buried in the cold test pit.

Removal of the large items needs to be done in a careful and deliberate manner because in a hot environment, generation of dust and spillage of debris must be minimized. Large and difficult to remove objects can present particular problems when removing the object from the digface for sizing. Materials are often interlocked or intertwined and are difficult to grasp, remove, and size. Sludge/grease mixtures can be tricky to handle because they can drip if a container is breached, which spreads more contamination and hampers cleanup efforts. Cable and large wires can become wrapped around many other objects at the digface and beyond and can be particularly difficult to remove.

The goal of the retrieval demonstration was to show that commercial equipment can handle and size the type of debris and waste configurations discussed here, while maintaining a minimum production rate of $80 \mathrm{yd}^{3} /$ day. To obtain this goal, several configurations of equipment and end effectors were tested in the ficld and measurements of their effectiveness obtained. Also, another long standing issue has been whether it is more effective to excavate from abovegrade or belowgrade. The field testing examined both of these positions to see if there are advantages or drawbacks to working from these positions. 
CAT proposed that several different types of equipment and end effectors be tested in the field. These included a $325 \mathrm{~L}$ excavator (referred to as $325 \mathrm{~L}$ ) with Balderson thumb end effector, $935 \mathrm{C}$ track loader (referred to as 935) with multipurpose bucket, EL200B excavator (referred to as EL200) with front shovel, and an IT28B integrated tool carrier with a grip and grab end effector (referred to as IT28 with grip and grab). These machines were selected from CAT's standard production models to maximize reliability during the test. Other support equipment included an IT28B integrated tool carrier for the transport of waste storage boxes from the cold test pit to the waste dumping area, and a 235B excavator outfitted with a pair of Allied-Gator shears (referred to as the shear) to be used for cutting and sizing large objects extracted from the pit.

For additional background information, refer to Test Plan for the Retrieval Demonstration, ${ }^{1}$ and the "Statement of Work for the Retrieval Demonstration."

\subsection{Objectives}

The primary objective of this demonstration was to evaluate the effectiveness of the full-scale equipment and end effectors chosen for retrieving buried waste forms that are typical of buried TRU waste at the INEL and other DOE sites. Specific objectives include

1. Retrieve an average of $80 \mathrm{yd}^{3} /$ day of simulated buried waste, including materials from the stacked drums and boxes cell, earth berm, and random dumped drums and boxes and large objects cell. The $80 \mathrm{yd}^{3} /$ day goal has been established by Environmental Restoration as a target value for the retrieval and treatment rate of TRU buried waste. For additional information concerning the stated production goal, refer to the Buried Waste Integrated Demonstration Test Objectives. $^{3}$

2. Minimize the spread of dust during excavation by making slow, deliberate motions to lessen agitation of soil at the digface during excavation. Likewise, use care when transporting the load of waste from the digface to the funnel and transport box for dumping to minimize spiilage.

3. Determine if removal of buried waste from belowgrade or abovegrade is more productive.

4. Determine the volume rate of retrieval for different waste orientations. Assess the average density of the waste/soil matrix.

5. Determine the correct suite of end effectors required to efficiently exhume the buried waste: and soil.

6. Determine how well the technology lends itself to remotization.

7. Produce an rough order of magnitude (ROM) cost to remotize the primary equipment used in the demonstration.

8. Determine if he use of closed circuit television can enhance and improve operator views of the work area. 


\section{PROJECT ORGANIZATION}

The general organization and responsibilities for key project personnel are shown in Figure 2.

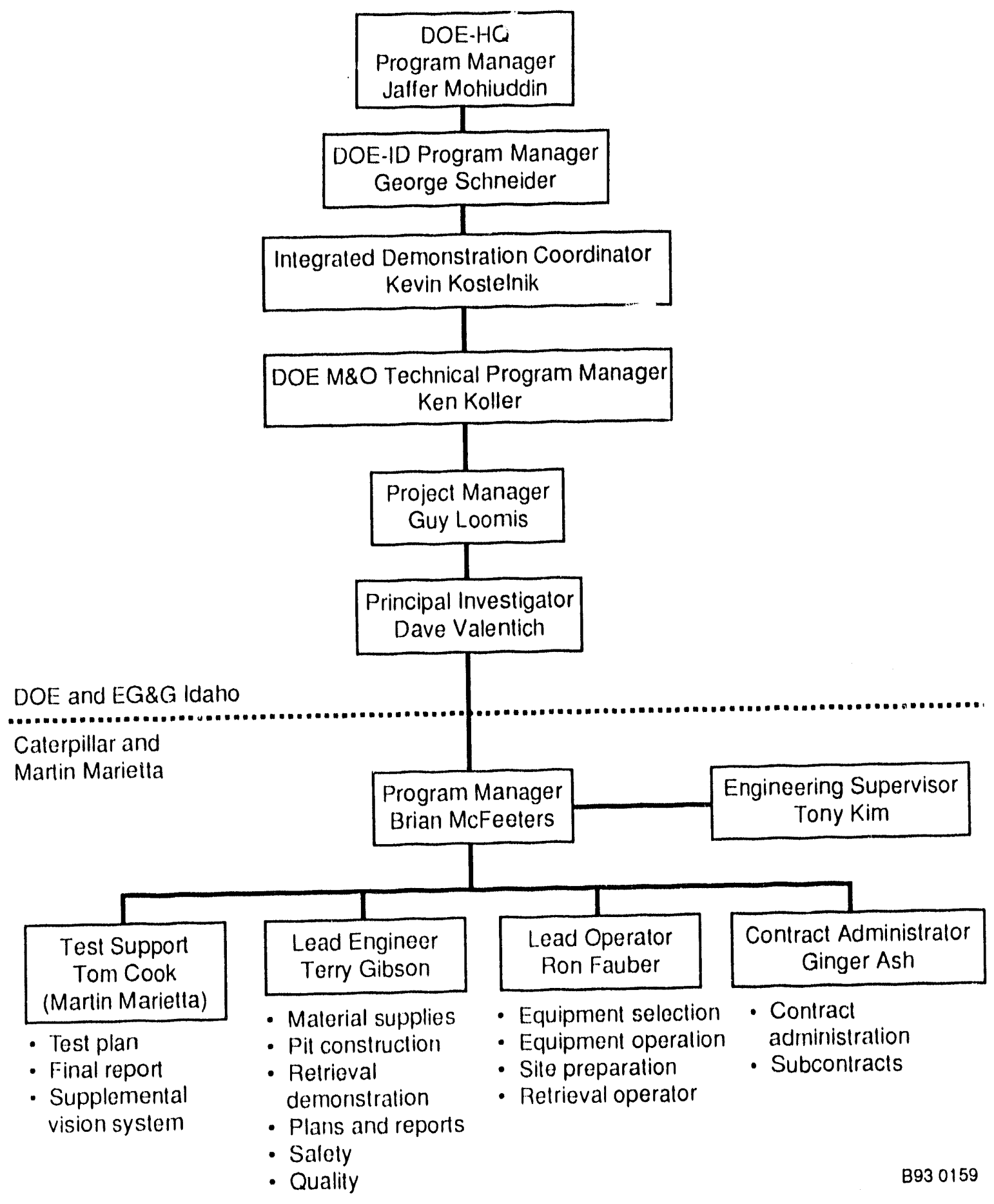

Figure 2. Project organization chart. 


\section{PROJECT DOCUMENTATION}

\subsection{Test Plan}

A test plan for the retrieval demonstration was prepared before the start of the field work. Test Plan for the Retrieval Demonstration ${ }^{1}$ gives specific information on the background, objectives, data quality, execution, and data recording for the project. This document was used as guidance for conducting the day-to-day operations in the field for the retrieval demonstration. The test plan was followed closely with only two notable exceptions. First, the test plan called for excavation of the third pass to be made from the abovegrade position with the funnel and transport box positioned belowgrade. This was changed to relocate the funnel and transport box abovegrade near the excavator. Positioning the funnel belowgrade created a potential safety hazard because of the length of the excavator stick. The funnel would have to be placed dangerously close to the digface where pitface sloughing would threaten the safety of the driver of the IT28 with hopper. Also, because the funnel would have to be placed so close to the digface, it would have been possible for the funicl to obstruct the excavator's work area. This aspect of the test was not critical, and it can be reasoned that if this configuration were necessary, it would not be a problem to load debris from abovegrade to belowgrade with a longer excavator stick. The second variation involved the way in which the fourth pass was excavated. The test plan specified that this pass would be dug from the abovegrade position. For exhibition purposes, it was decided to excavate half of the fourth pass from abovegrade, and half from belowgrade. The field work had progressed far ahead of schedule so that it was apparent the fourth pass could be removed in less than 1 day. A number of visitors were scheduled to observe the removal of the fourth pass, so in the interest of displaying the 325L's versatility, it was decided to demonstrate the machine could work from either position. This was likewise not a major alteration to the test plan because sufficient information was obtained concerning the effectiveness of operating from the abovegrade position.

\subsection{Environment, Safety, and Health Plan}

An environmental, salety and health (ES\&H) plan was prepared by CAT for the retrieval demonstration. Ihe EG\&G Idaho Safety Momual was used as a reference for preparation of the ES\&H plan. The plan addressed all aspects of lield safety and all personnel associated with the project were required to familiarize themselves with the plan. CAT assigned a full lime safety representative at the job site while lield work was in progress. An EG\&G Idaho certified safety engineer reviewed and approved the ES\&H plan before the start of field work.

The ES\&H plan was adhered to, and the field demonstration was conducted in a safe and environmentally responsible manner. There were no injuries, damage to equipment, or threat to the environment.

\subsection{Quality Plan}

CAT prepared a quality plan for the project. This plan was based on requirements contained in Nuclear Quality Assurance, NQA-1, Section II. All project personnel were familiarized with the quality plan hefore starting work on the retrieval demonstration. An EG\&G Idaho certified quality 
engineer reviewed and approved the quality plan before award of contract to CAT. The quality plan was carcfully followed during the project, and as a result, there were no quality issues.

\subsection{Project Management Plan}

A project management plan (PMP) was developed for the retrieval demonstration within the first month after contract award. This document addressed availability of resources, qualifications of personnel assigned to the project, and overall execution of the project. The PMP was reviewed by EG\&G Idaho project management personnel and approved. The PMP was used as a planning, baseline, and guidance document that contributed to a successful project. 


\section{TEST EXECUTION}

\subsection{Test Set-Up}

\subsubsection{Construction of Cold Test Pit}

The cold test pit, constructed at the CAT ETC, was built of materials resembling those found in the buried waste pits and trenches, with the exception that the materials selected were nonhazardous and nonradioactive. A sampling of the types of materials that were used to simulate waste in the pit are shown in Figures 3 through 6. Materials included metal, wood, cloth, plastic, simulated sludge, concrete, asphalt, and cardboard. Several large objects were also required for construction of the pit including a tank (see Figure 7), a pickup truck bed, lengths of I-beam and steel pipe, a machine tool (see Figure 8), steel cable, and a 6-ft metal cube (see Figure 9).

Much of the matcrial used for construction of the pit was obtained locally as scrap or recycled material either from CAT's manufacturing processes or local recyclers. The simulated sludge was comprised of a mixture of MICRO CEL E, oil dry, and vegetable oil. This material was mixed onsite in a cement mortar mixer (see Figure 10). Poured concrete was obtained from a local supplier. The $6-\mathrm{ft}^{2}$ cube was welded together using old steel bins obtained from scrap metal. All other large objects were acquired from CAT's recycling programs.

The cardhoard boxes were not structurally sound to fill before moving them into the pit. To overeome this deficiency, wood frames made of $2 \times 4$-in. lumber (two per box) were constructed around each of the boxes, and steel bands were placed around the boxes to hold them together while they were being filled (see Figure 11). Also, boxes in the stacked pit were placed empty in the pit before filling, and then material was dumped in the box. The boxes in the random eell were filled on the bank and then pushed in pit. Steel bands around the boxes were cut once filling and placement was completed.

Table 1 gives a chronological history of the cold test pit construction. The stacked pit was dug into the hillside to permit the use of forklift-type equipment without the need for an access ramp or crane. Emply boxes were set in place and filled with debris. An IT28 with forks and an IT28 with grip and grab were used to transport and fill the boxes and to transport and stack the drums in the stacked eell (see Figures 12 and 13). The random dumped cell was dug as a pit from grade, and filling was accomplished by dropping containers and large objects in from the side (see Figures 14 and 15). This method of placement approximates the scattering of material that would occur from a tiltbed truck dumping the waste into a pit or trench. Once the pits were lilled with waste, they were saturated with water to hasten deterioration of the cardboard boxes and drums. The stacked pit was saturated with approximately 5,000 gal of water from a CAT water wagon (see Figure 16). A D11 bulldozer was then used to backfill the stacked pit (see Figure 17). Once the random pit was filled with waste material, work ecased until the next day, at which time the pit would have been soaked with water and backlilled. One inch of rain fell overnight saturating the random pit (additional water was not required). The pit was back(illed with a $330 \mathrm{~L}$ excavator and compacted. Following backlilling, the cold test pit was contoured using a $140 \mathrm{G}$ motor grader to produce a flat surface with 
Table 1. Brief chronological history of cold test pit construction.

Date

Work Summary

5/12/93 Started work at demonstration site. Waste material began arriving at site.

5/17/93 Dug stacked pit to rough dimensions. Waste form construction continuing.

5/25/93 Shaped stacked pit to final dimensions. Started filling stacked pit with waste forms.

5/27/93 Stacked pit filling completed. Stacked pit saturated with water and backfilled and compacted.

6/1/93 Dug random pit. Started filling random pit with waste forms.

6/2/93 Random pit filling completed.

6/3/93 Rain previous night saturated pit adequately. Backfilled random pit and compacted.

a slight slope for drainage. The cold test pit was then covered with tarps to help prevent moisture secping in from the surface.

Appendix $A$ is a copy of the Requirements Verification Matrix, which was completed during construction of the cold test pit. Virtually all requirements were fulfilled with the exception of some: minor variations (noted in the appendix) that did not impact test quality.

\subsubsection{Overview of Retrieval}

The retricval demonstration was planned to occur in passes, as shown in Figure 18. The first two passes would be excavated from belowgrade with pass one starting at the right (east) end of the digface, progressing to the left, and pass two returning from the left to the right. The third and fourth passes would be abovegrade with pass three starting at the left end of the digface, progressing to the right and pass four returning from the right to the left.

The pit consists of three sections (see Figure 19); Section A-Random dumped pit section, Section B-Earth berm, and Section $C-S t a c k e d$ pit section. Each section is configured to represent a different arrangement of buried waste that would be expected to be in contaminated pits and trenches.

There are four retrieval conditions where a variety of equipment configurations (equipment configuration is defined as a machine with a specific end effector at a particular position relative to grade) will be evaluated. The primary equipment to be evaluated was the $325 \mathrm{~L}$ excavator with Balderson thumb end effector. It was planned to use the $325 \mathrm{~L}$ abovegrade and belowgrade in each of the different sections of the pit. Additionally, as termined by the observers, depending on how well the excavator performed, other equipment would also be tested. A front shovel (EL200) excavator, IT28 with grip and grah, and 9.35 track loader were planned to be used in the pit. 


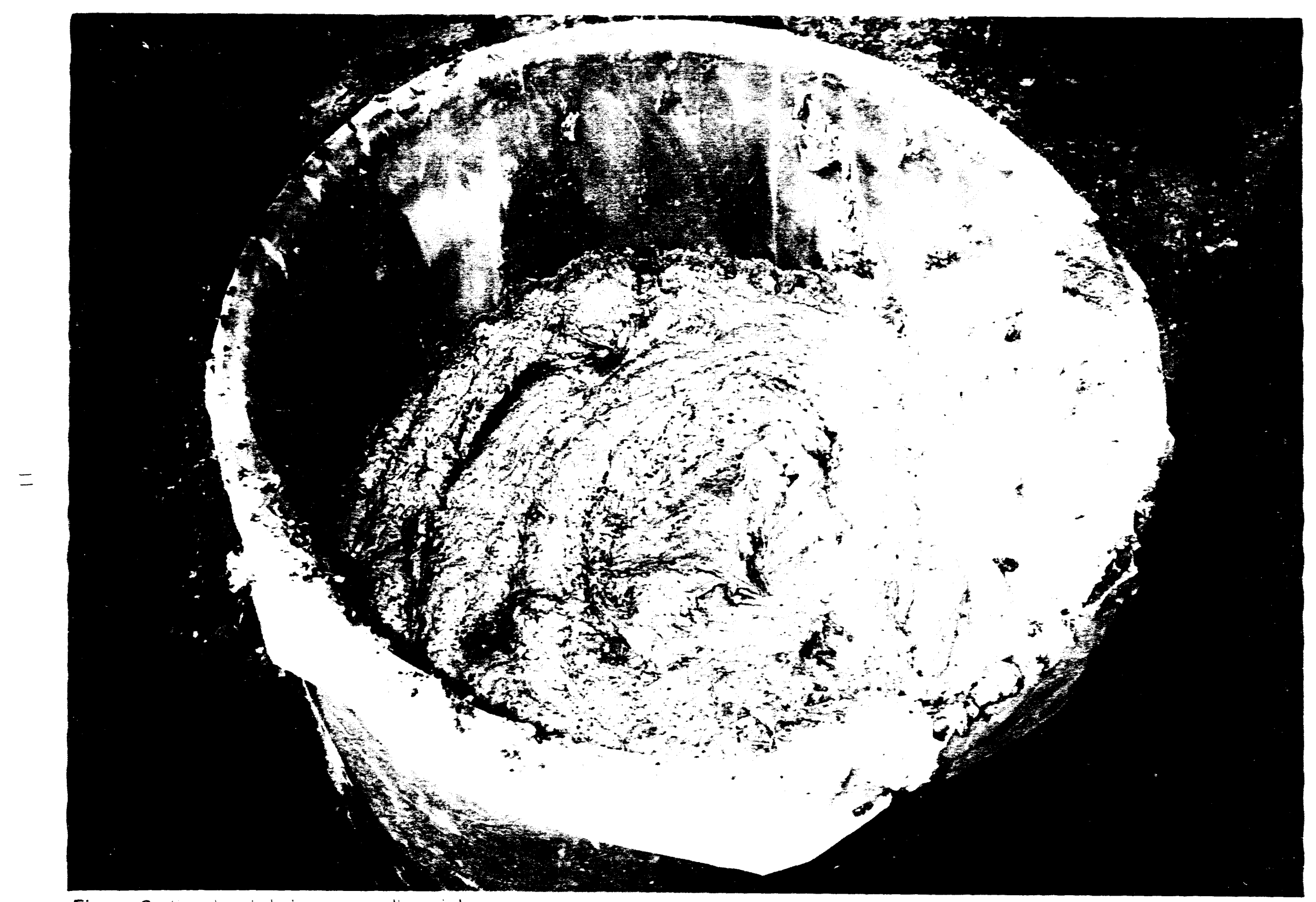

Figure 3. Simulated sludec in a cardhourd drum. 


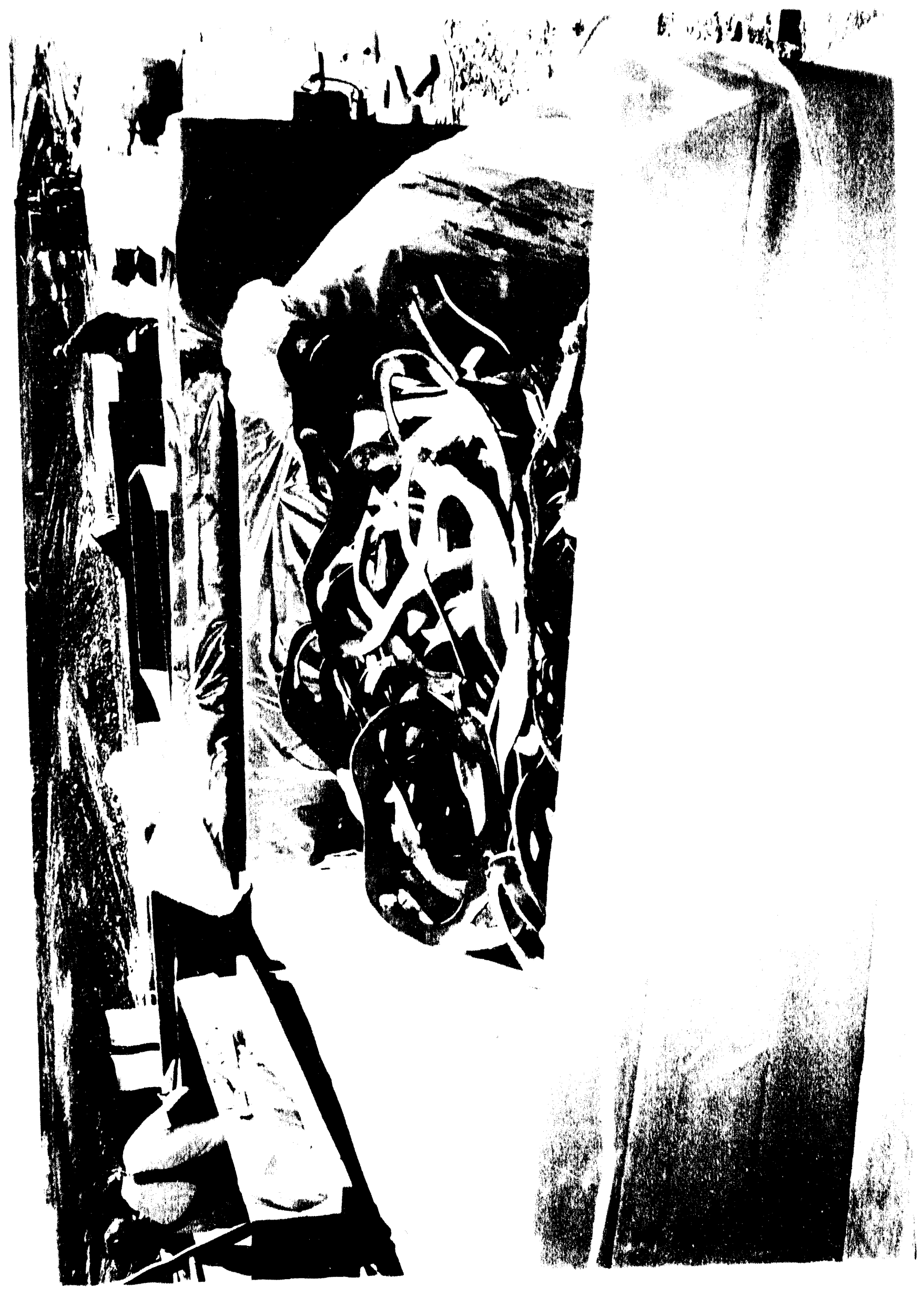



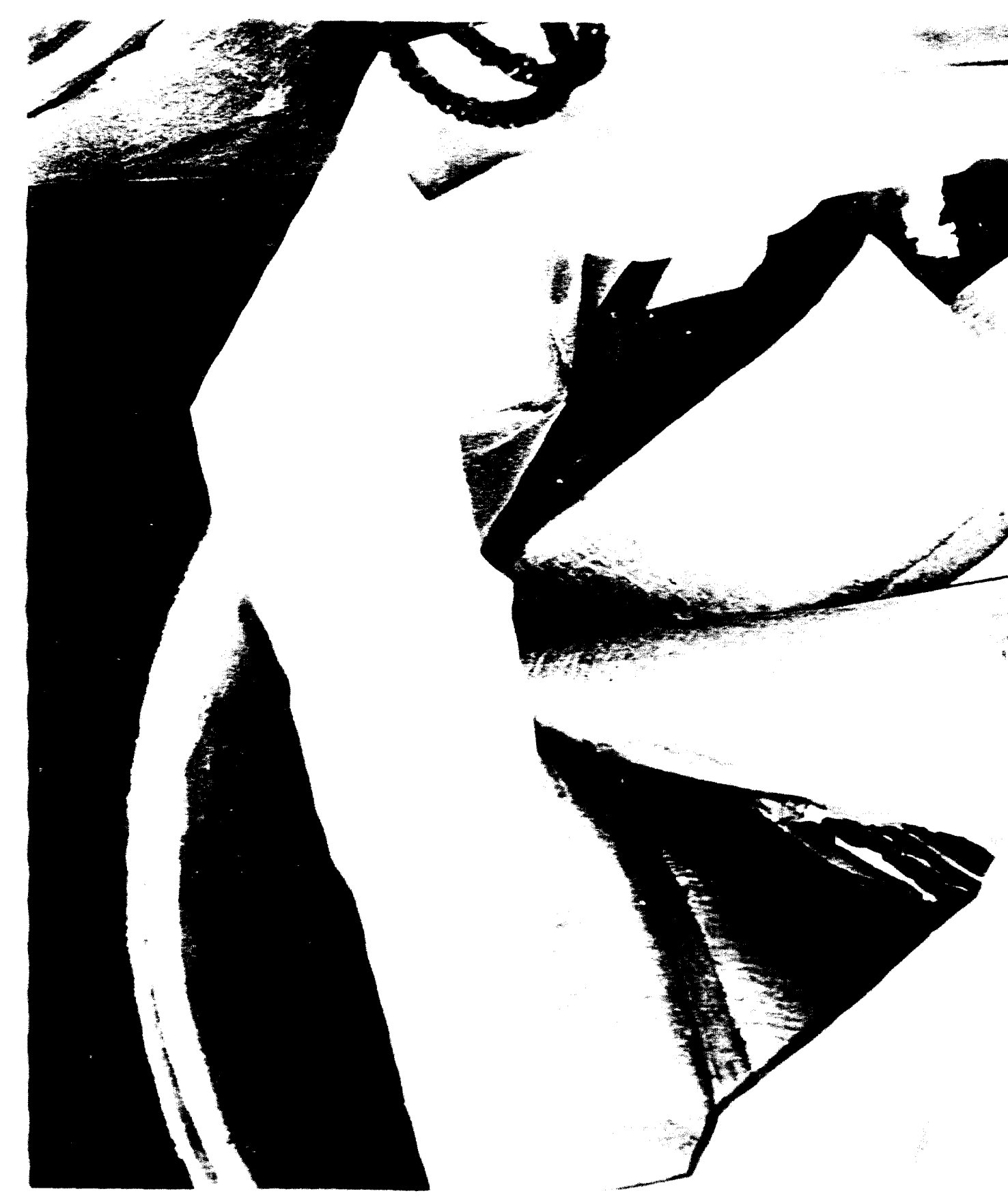

N
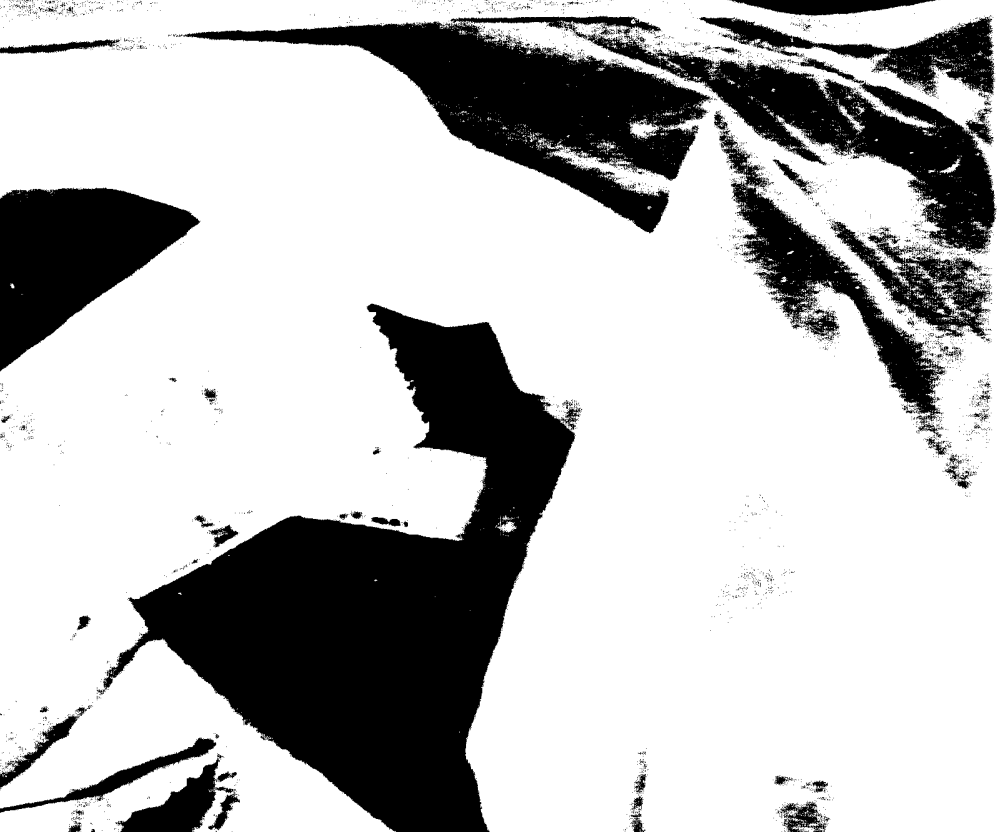

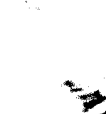
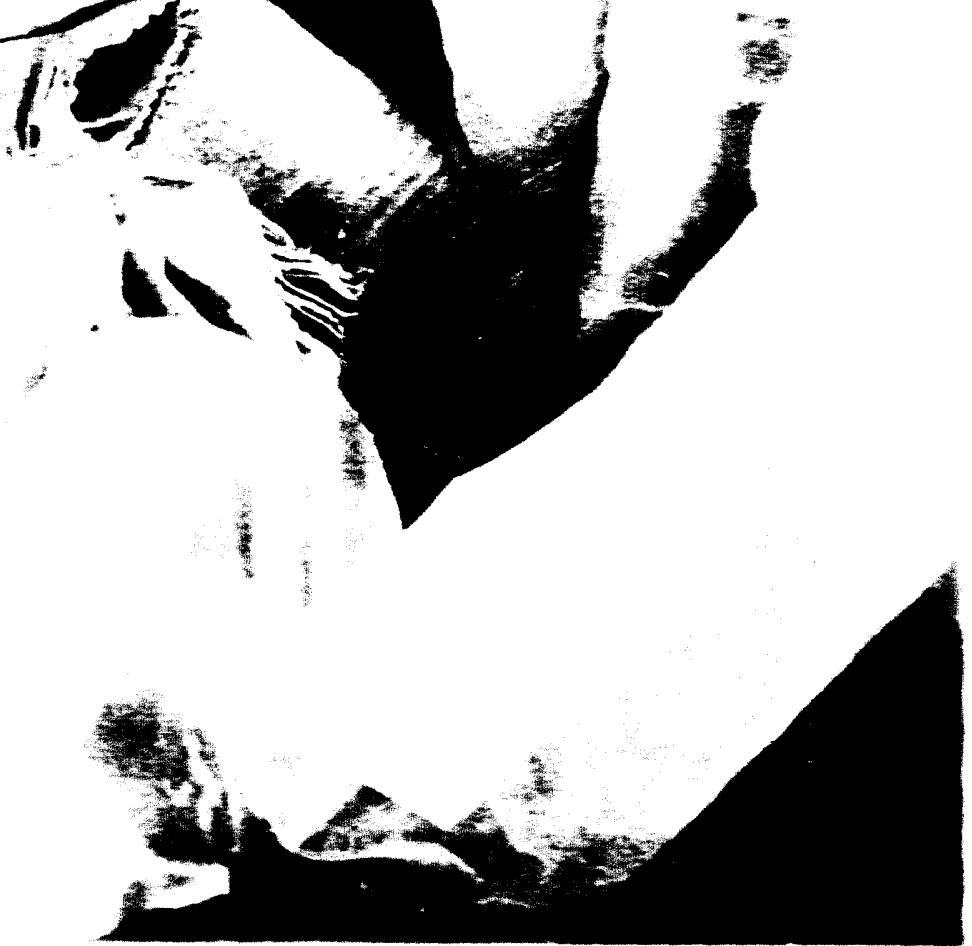


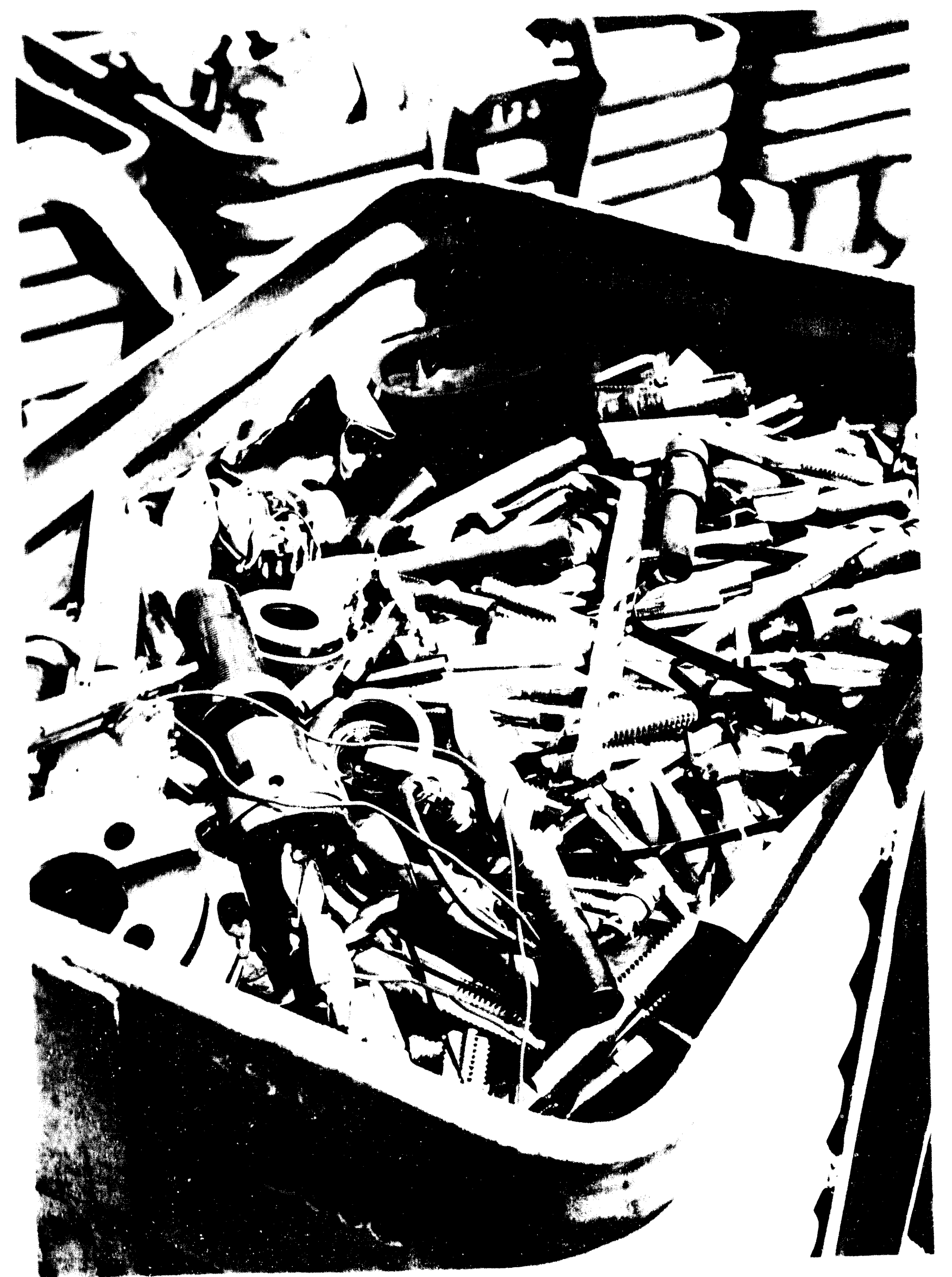




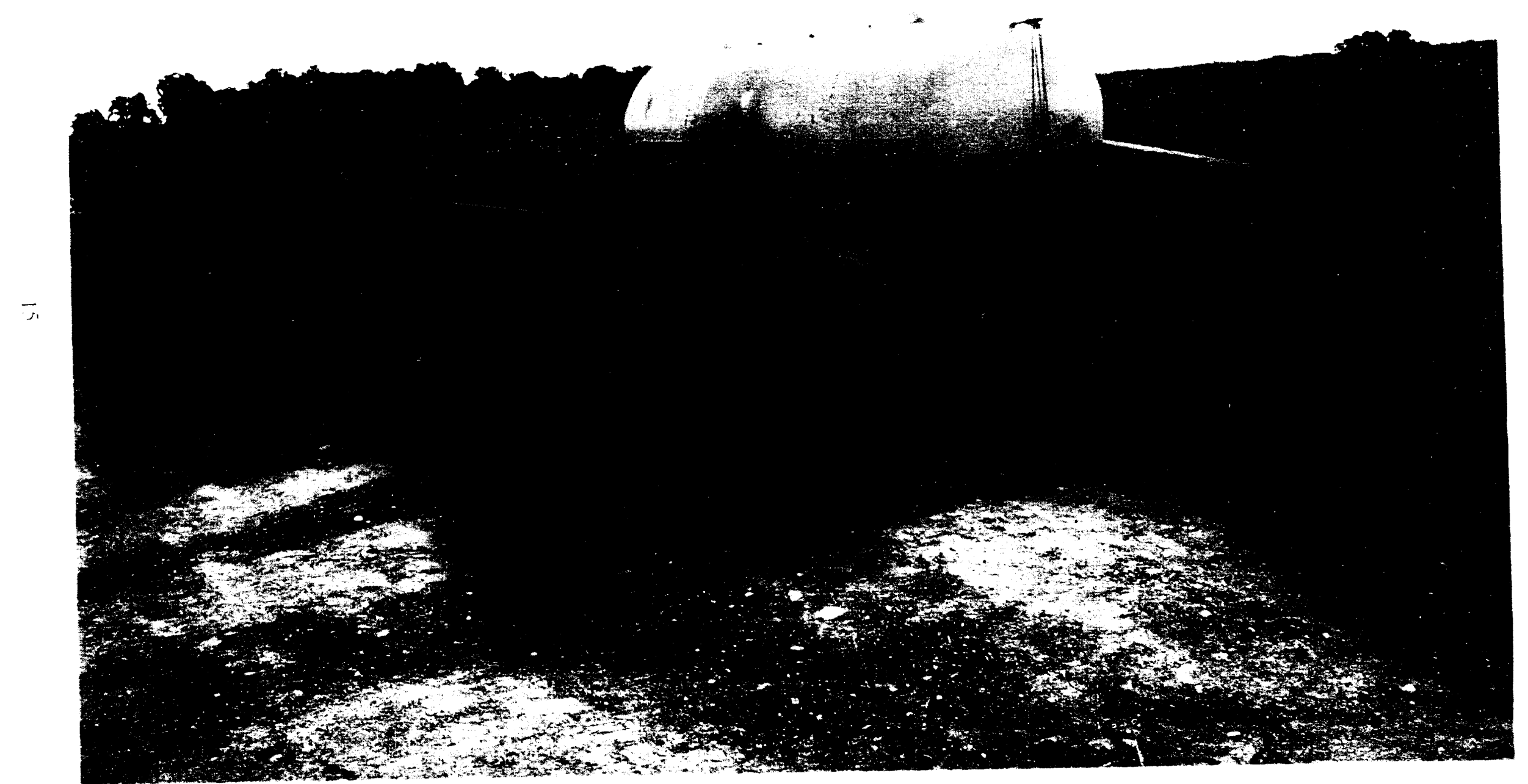

Figure 7. Stordec lank. 


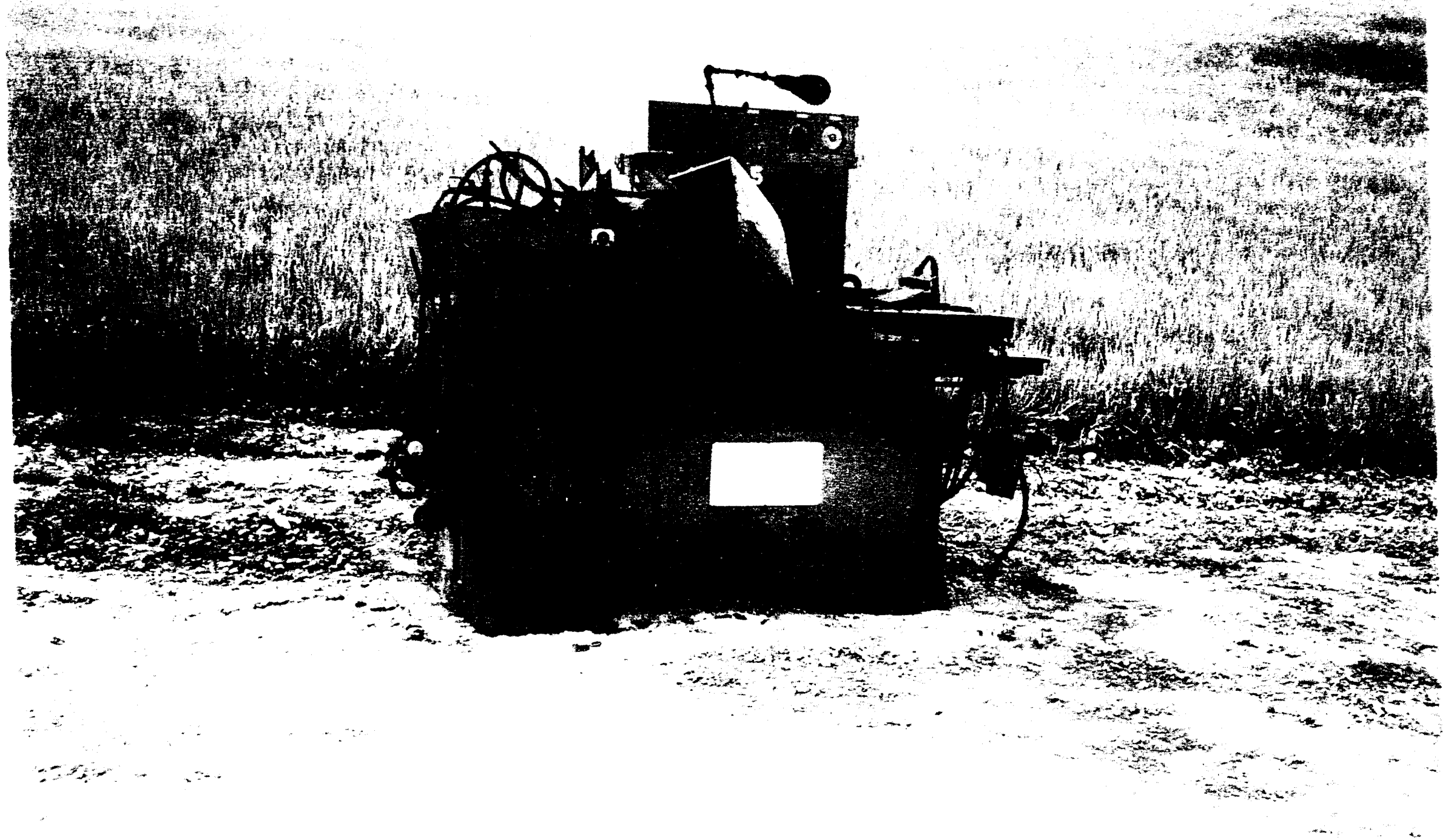

Figure of 


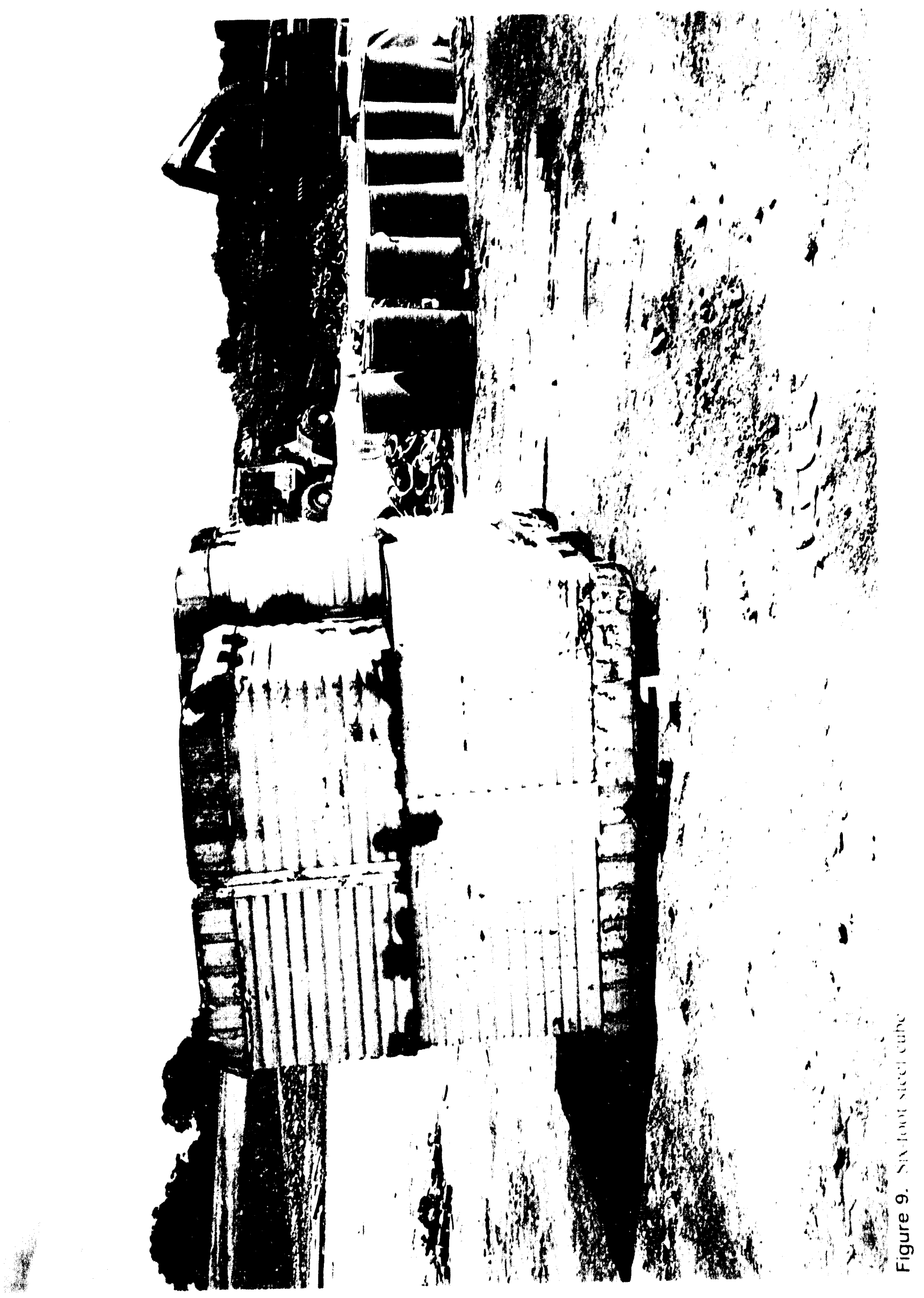




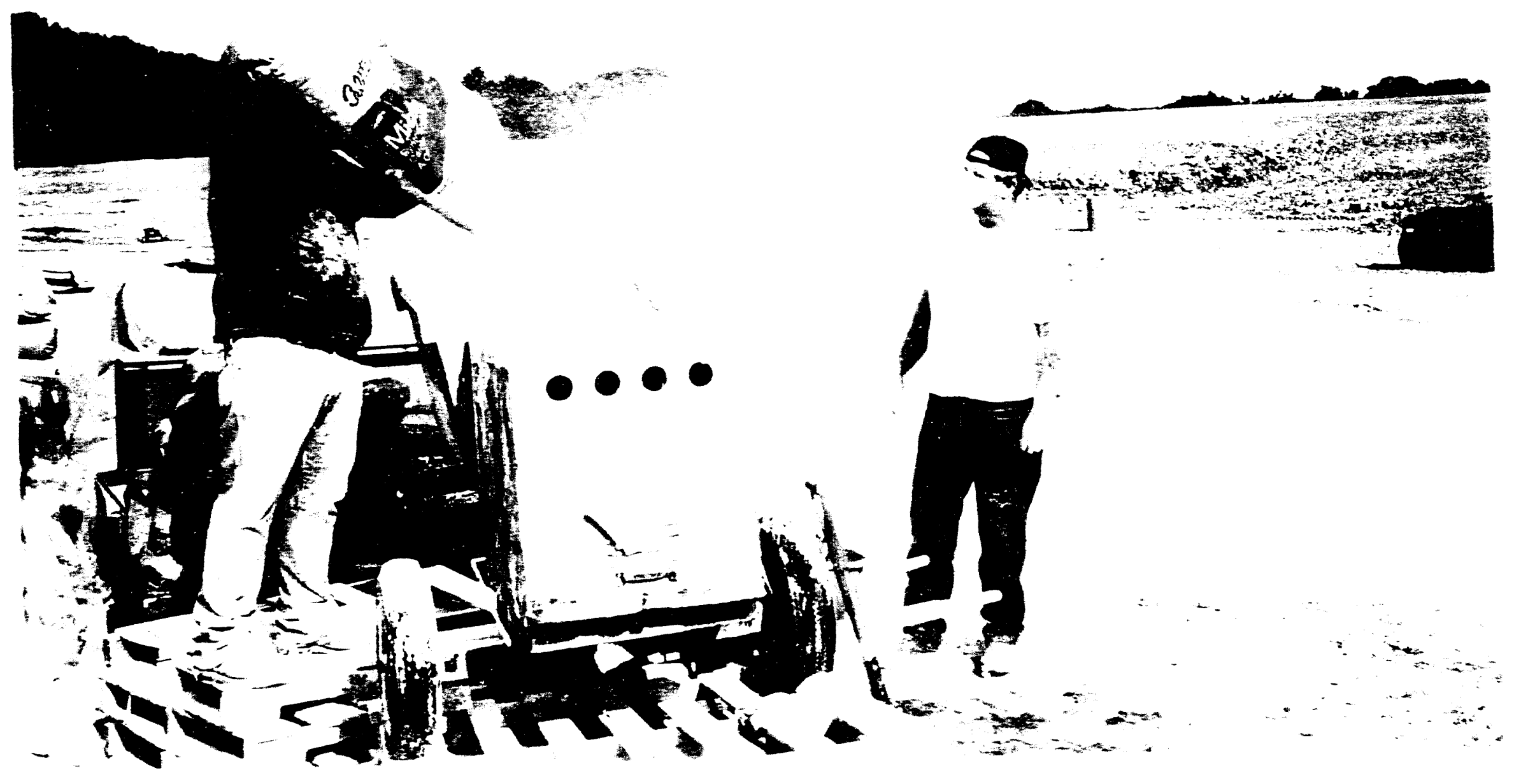




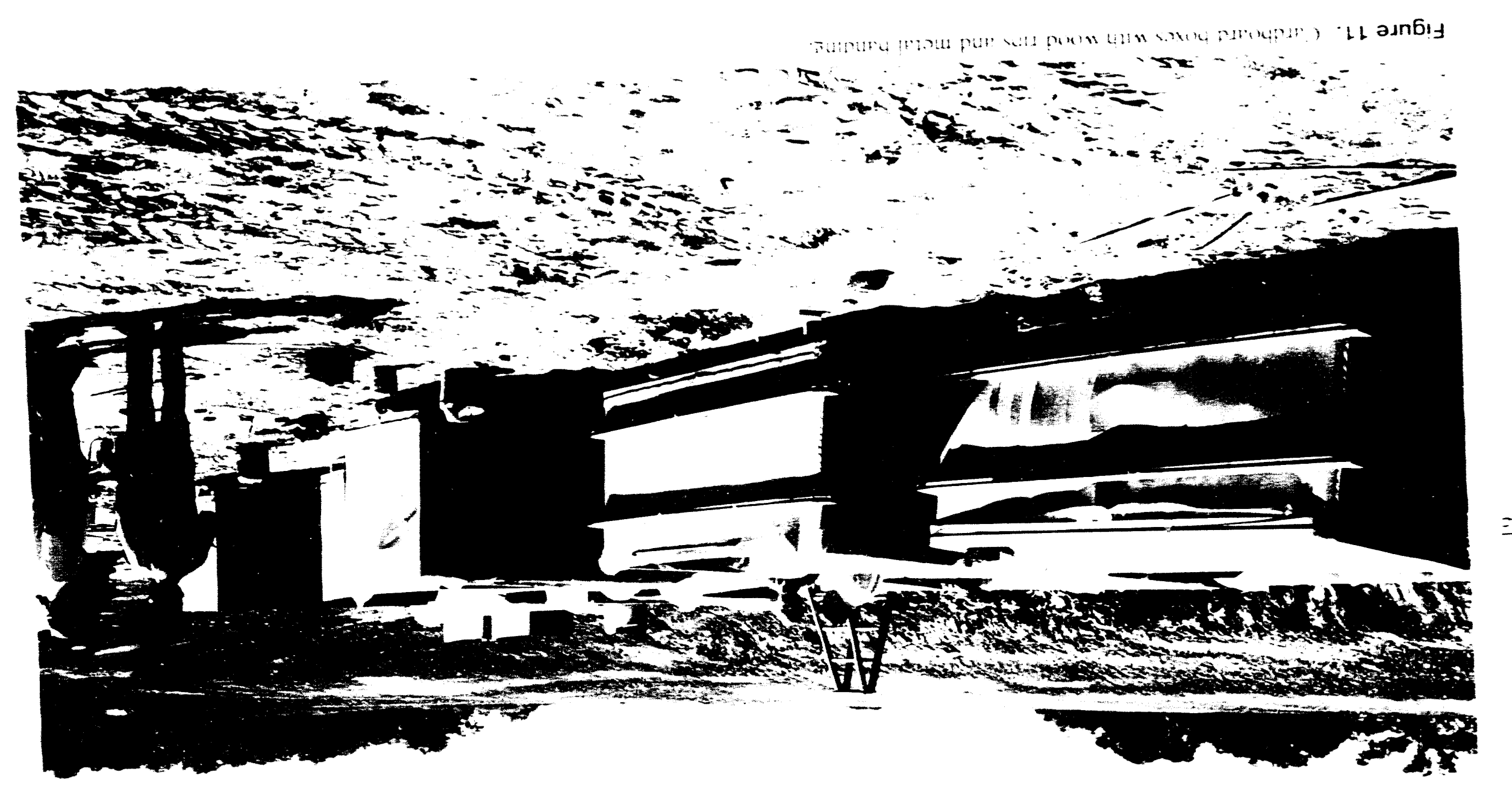




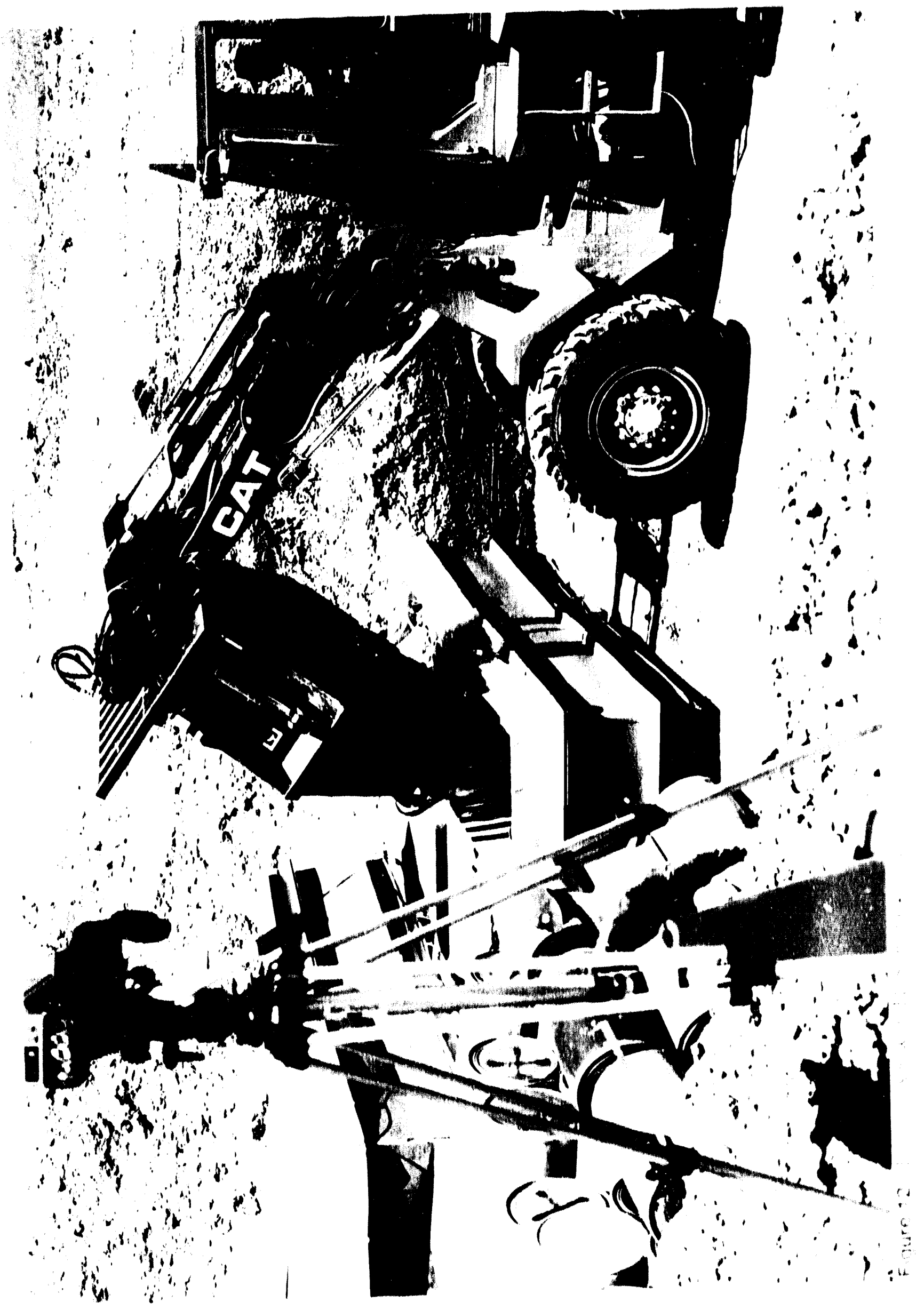




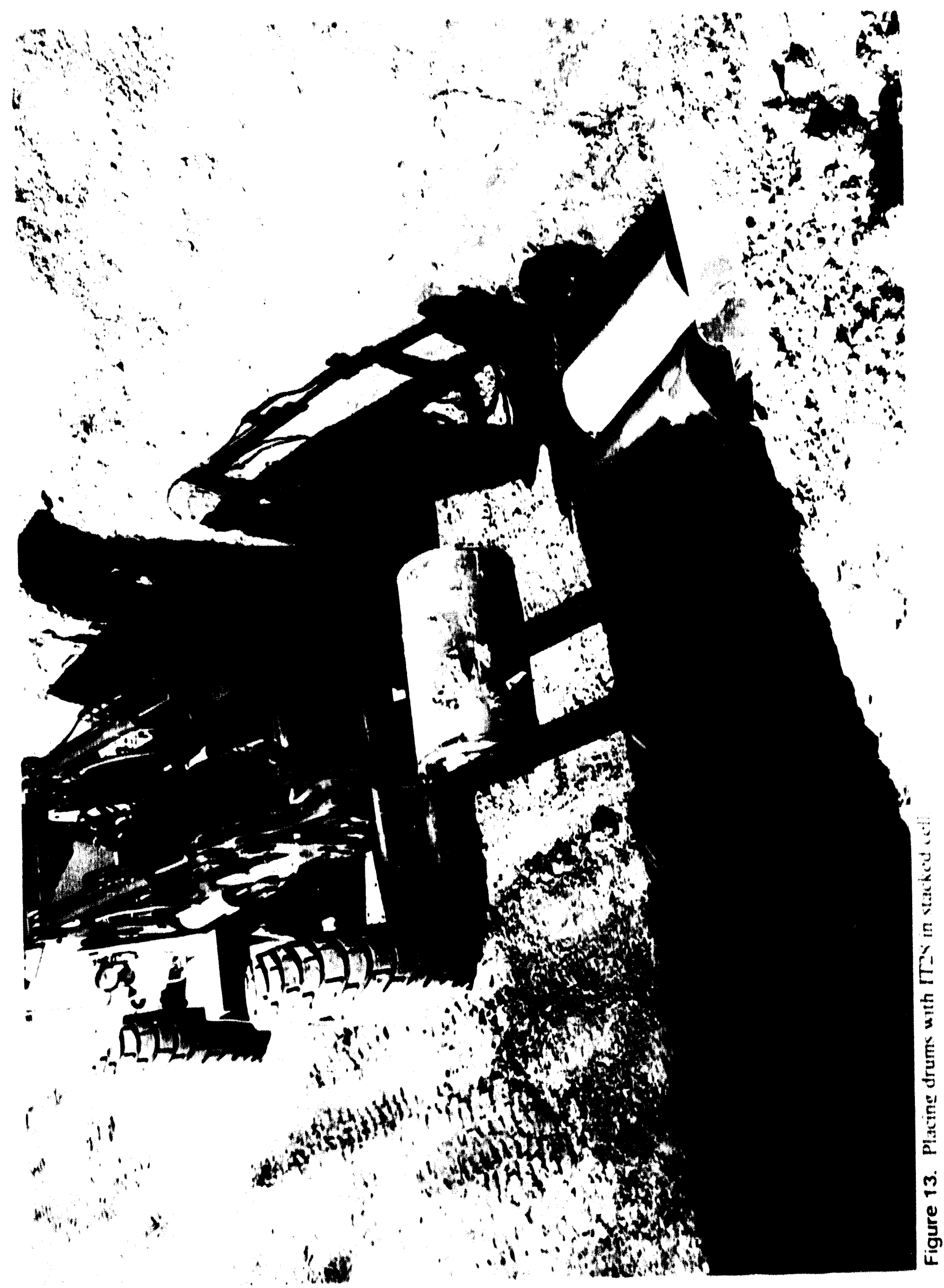




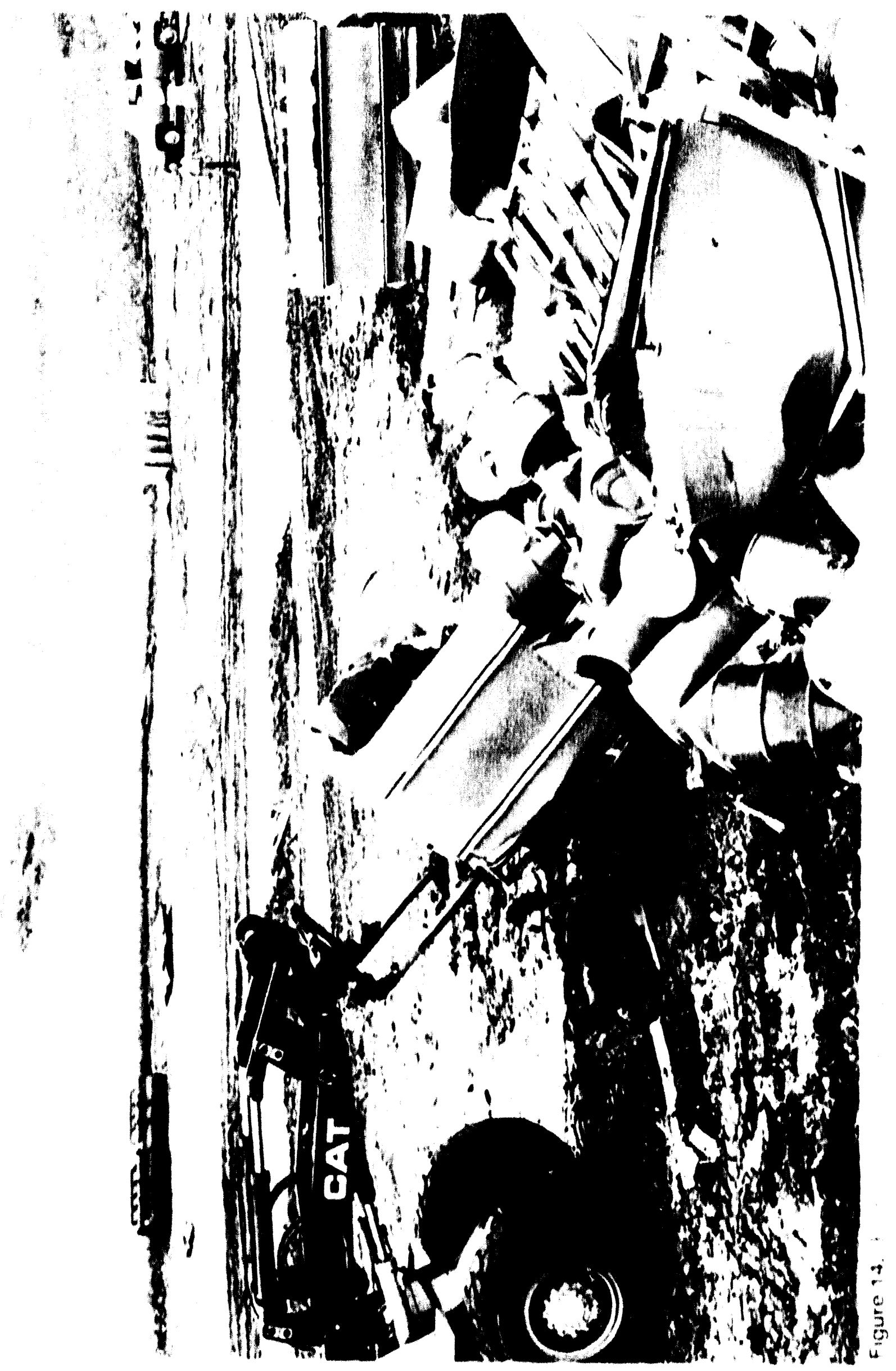



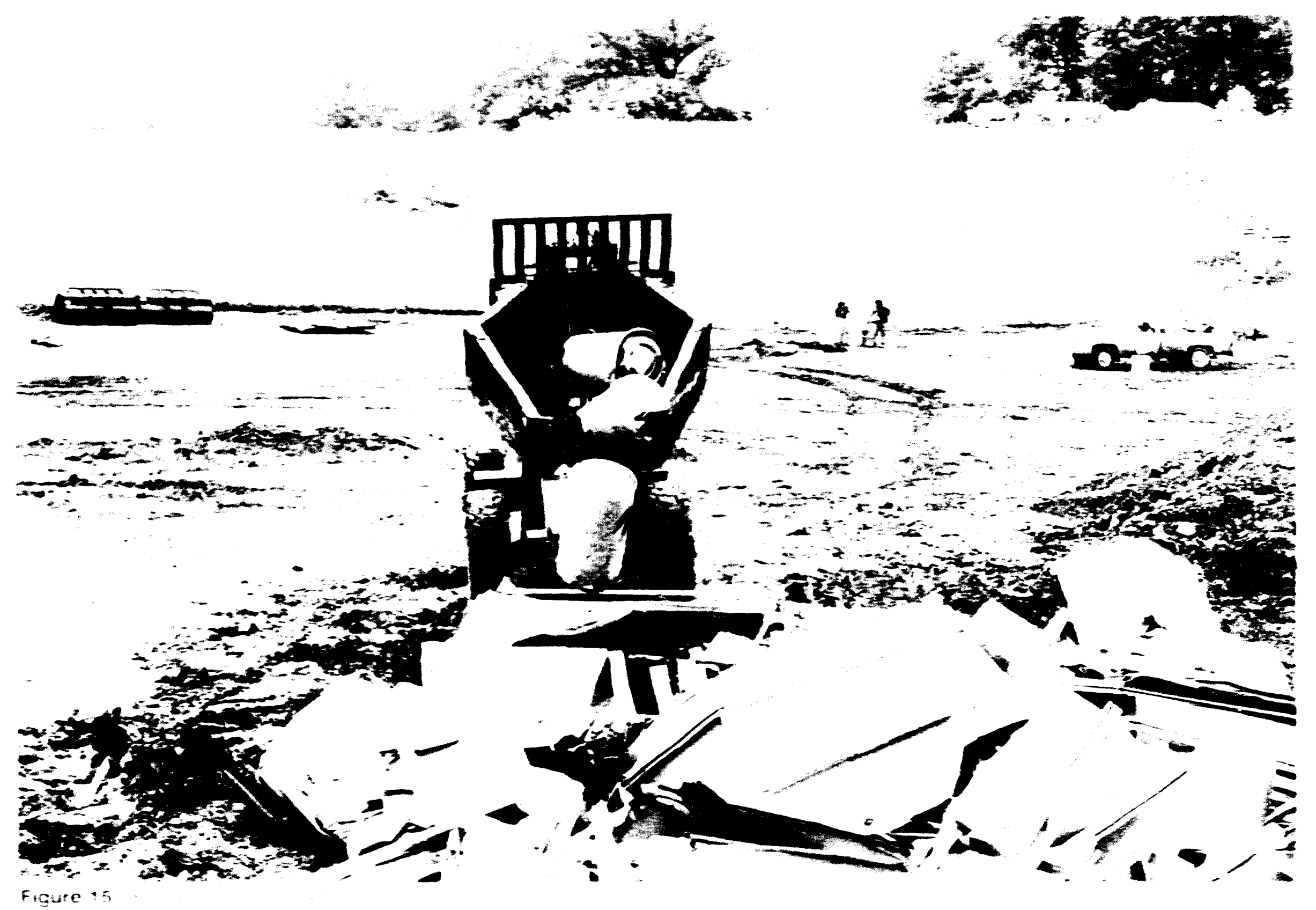


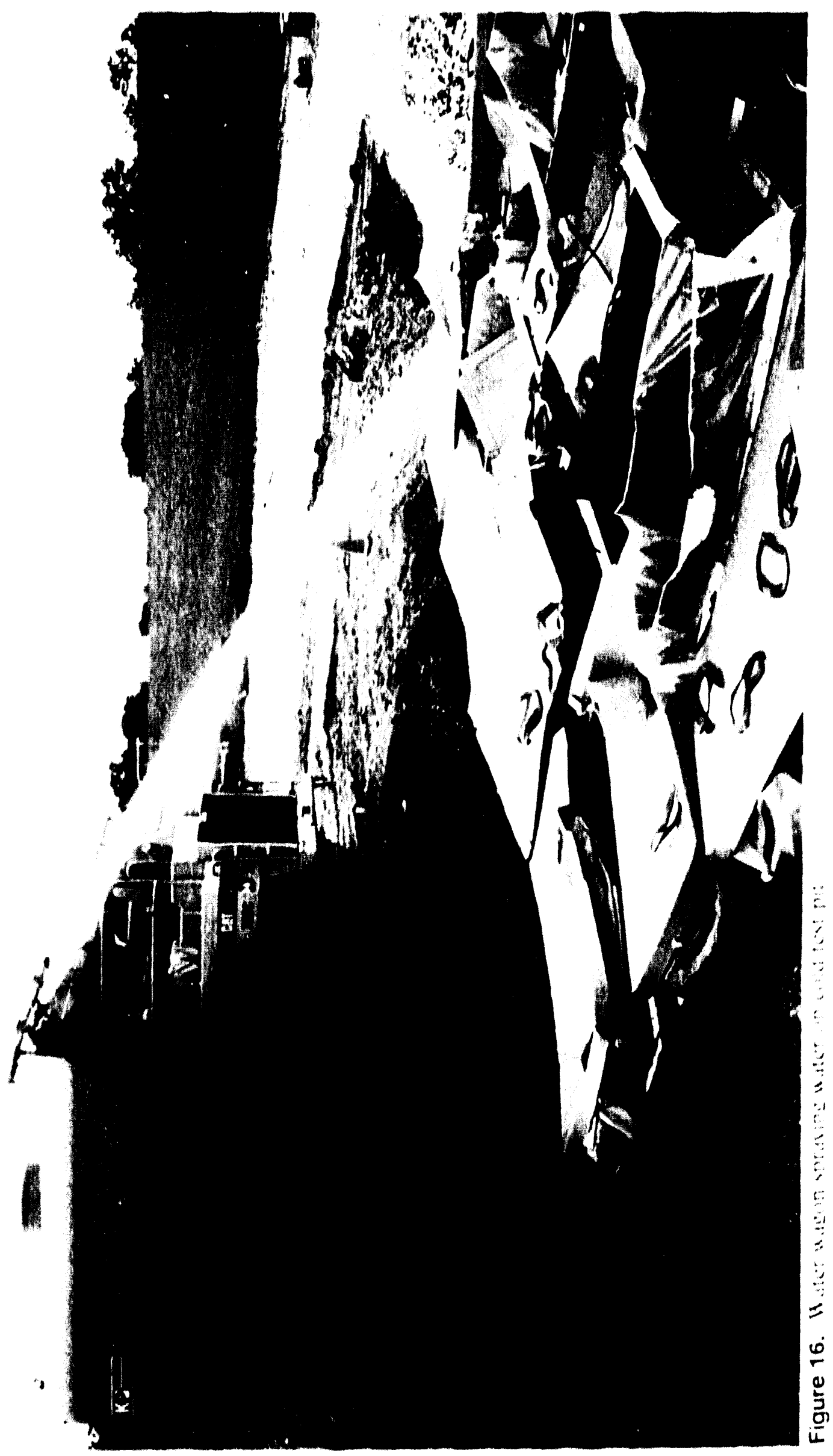




$$
=
$$




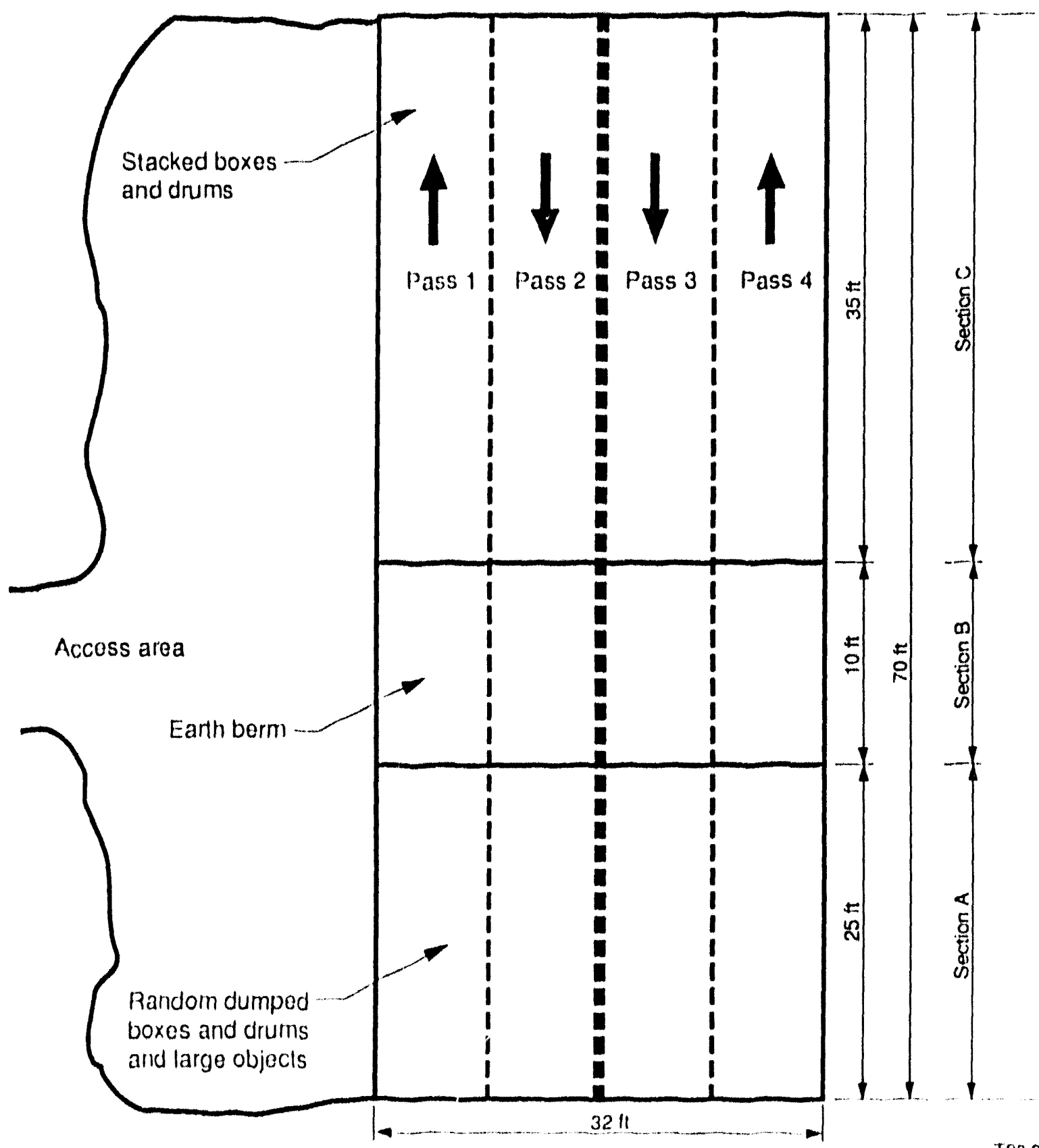

Nol to scale

Figure 18. Excavation of cold lest pit occurred in four passes. 


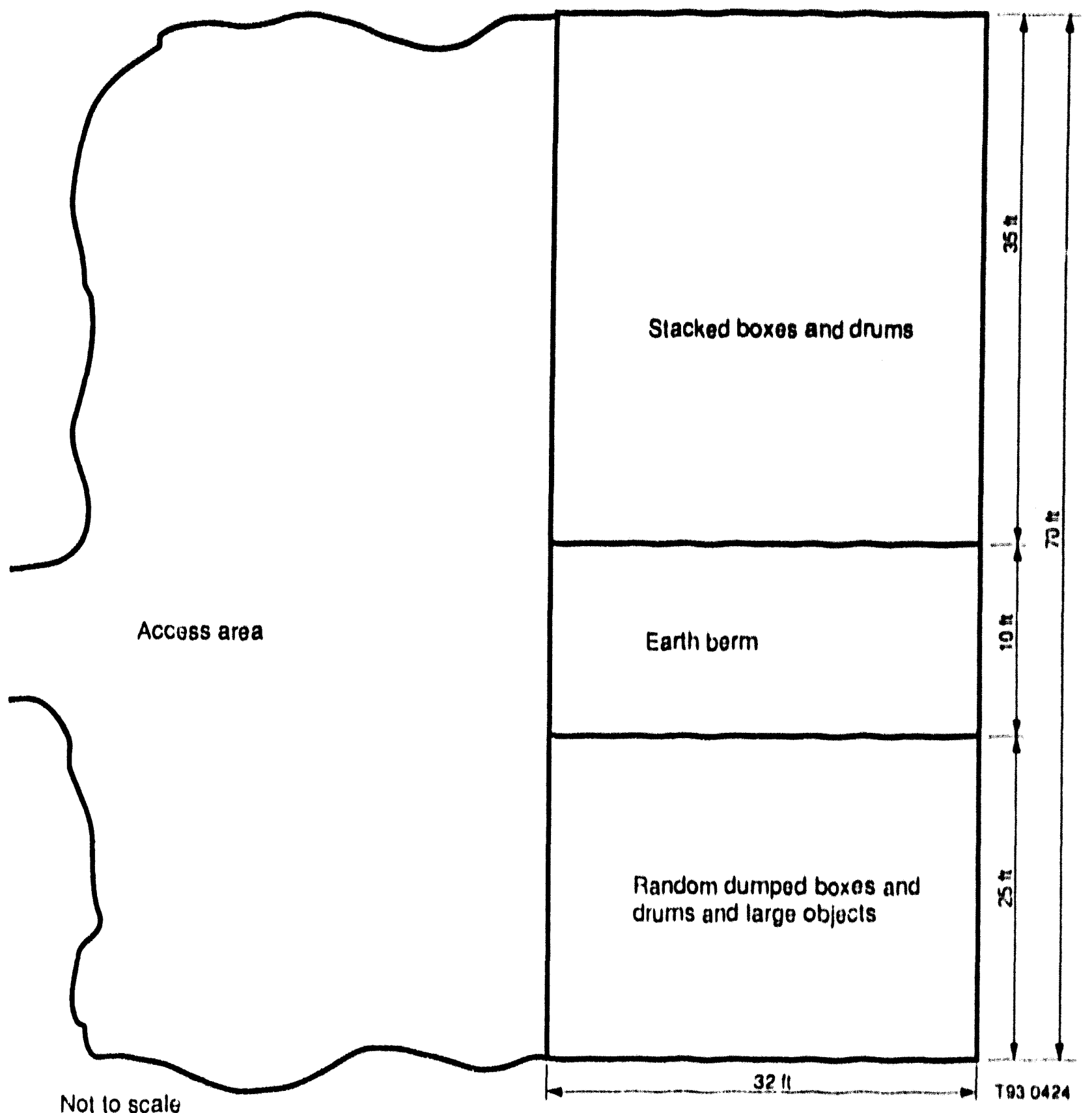

Figure 19. Cells of the cold test pit. 
For all passes, a CAT 235 excavator mounted with shears and a CAT IT28 with transport box allachment were available for required culting and transportation operations. The concept for excavation of the pit was as follows:

Pass *1: Belowgrade: Start in Section A, work through B, and stop after completing C.

1. Bricf all operators on the objectives of the demonstration and desired standards regarding dust containment, spillage, and safe operation. Emphasize that accuracy is more important than speed.

2. Position funnel and stecl waste containers at locations convenient for the excavator operator 10 unload the bucket. All equipment and vehicles will be operated belowgrade.

3. Use the 325L excavator with full width Balderson thumb for excavation and placement of material in the funnel.

4. Set large objects off to the side for the 2.35 with shear to cut into small pieces for placement in the funnel. The $325 \mathrm{~L}$ will then place the sheared material in the funnel. Objects too large 10 size will be set off to the side.

Pass \#2: Belowgrade: Start in Section C, work through B, and stop after completing $A$. This completes helowgrade excavation.

1. (Re)brief all operators on the objectives of the demonstration and desired standards regarding dust containment. spillage and safe operation. Emphasize that accuracy is more important than speced.

2. Reposition funncl, steel waste containers, and equipment as required to convenient locations.

3. Use the $325 \mathrm{~L}$ excavator with full width Balderson thumb for excavation and placement of matcrial in the funnel.

4. Set large objects off to the side for the 2.35 with shear to cut into small pieces for placement in the funnel. The $325 \mathrm{~L}$ will then place the sheared material in the funnel. Objects too large Io siec will be sel off in the side.

Pass \#3: Abovegrade: Start in Section C, work through B, and stop after completing A.

1. (Re)hrief all operators on the objectives of the demonstration and desired standards regarding dust containment, spillage, and safe operation. Emphasize that accuracy is more important than speed.

2. Reposition the funnel and stecl waste containers belowgrade.

3. Move the 325L excavator with lull width Balderson thumb and IT28 abovegrade, providing limber malting to lower ground pressure under the $325 \mathrm{~L}$ as required by prevailing conditions. 
As waste is excavated from the abovegrade position, it is loaded into the funnel and dumpster located belowgrade.

4. Set large objects off to the side for the 2.35 with shear to cut into small pieces for placement in the funnel. The $325 \mathrm{~L}$ will then place the sheared material in the funnel. Objects too large to size will be set off to the side.

Note: The above configuration is stated as originally planned, however, this was changed in the ficld because of safety concerns resulting from placement of the funnel and IT28 in too close to the digface.

Pass \#4: Abovegrade: Start in Section A, work through B, and stop after completing C. This completes abovegrade excavation.

1. (Re)brief all operators on the objectives of the demon.tration and desired standards regarding dust containment, spillage, and safe operation. Emphasize that accuracy is more important than speed.

2. Reposition the funnel and steel waste containers to the abovegrade position.

3. Keep the $325 \mathrm{~L}$ excavator with full width Balderson thumb and IT28 abovegrade, providing timber matting to lower ground pressure under the $325 \mathrm{~L}$ as required by prevailing conditions. Load debris and soil excavated from the abovegrade position into the funnel and dumpster, also located abovegrade.

4. Set large objects off to the side for the 235 with shear to cut into small pieces for placement in the funnel. The $325 \mathrm{~L}$ will then place the sheared material in the funnel. Objects too large to size will be set off to the side.

\subsection{Equipment}

Six different pieces of equipment were used during the retrieval demonstration. Listed in Table 2, this equipment represent a suite of machines and end effectors that were tested for buried waste retrieval, handling, sizing, and transporting. Backhoe and front shovel, tracked and wheeled, articulated and skid steered, skid swing (the same as skid steered, only for turning, not driving), and swing bearing (as found on an excavator) and varying reach aspects are all represented in the different machines used for the retrieval demonstration. In each equipment configuration, all of the equipment was operated from cither belowgrade or abovegrade.

A varicty of other equipment was used for general demonstration support. This included such items as dump trucks, motor grader, compactor, water wagon, articulated loader, and bulldozer.

Specific technical information, operating envelopes, capacities, power ratings, and related information concerning the equipment used is available in the Catepillar Performance Handbook. ${ }^{4}$ 


\subsection{Excavation, Sizing, Handling, and Dumping of Simulated Waste}

The removal of the simulated buried waste in the cold test pit constructed at the ETC occurred over a 9-day period starting on June 7 and concluded on June 15, 1993. An additional 2 days (June 16 and 17) were needed to dispose of the excavated waste and reclaim the cold test pit. This section of the report is a chronological accounting of the retricval work and commentary on observations made in the field about equipment performance, characteristics of the waste, and machine production capability. General preparatory work was required belore waste retrieval in the cold test pit could begin. Grading, contouring, and leveling of the immediate work area, storage area, and aceess roads into and around the Power Parade site at the ETC was accomplished. The tarps covering the surface of the cold test pit were pulled back and the digface exposed. A D11 bulldozer was used to trim excess dirt from the digface (see Figure 20) before starting excavation.

Monday June 7-In the morning, a final inspection of the test area and equipment was conducted. Final preparations of the area including miscellaneous grading was performed. The soil was damp due to heavy rains in the area but did not hamper the operation of equipment. The video equipment mounted on the 325L was double checked, and a review of how data would be collected was conducted. Pit boundaries were marked off, equipment was moved into position, and actual retrieval started at 1:(0) p.m. The first pass started on the east side of the pit, the random dumped barrels and boxes and large objects pit. The CAT 325L excavator outfitted with a Balderson thumb and located belowgrade was used 60 dig the soil and simulated debris (see Figure 21). The 235 excavator

Table 2. Primary equipment used for retrieval demonstration.

\begin{tabular}{|c|c|c|}
\hline Equipment item & Description & Primary use \\
\hline $\begin{array}{l}325 \mathrm{~L} \text { hydraulic } \\
\text { excavator }\end{array}$ & $\begin{array}{l}\text { 59.560)-lb machine weight, oulfitted with a } 10 \mathrm{ft} \\
6 \text {-in. stick for a maximum reach of } 34 \mathrm{ft} 11 \mathrm{in.} \\
\text { Flywhecl hp } 168 \text {. End effector is } 1 \mathrm{yd}^{3} \text { (struck) } \\
\text { Balderson bucket and thumb (Figure } 22 \text { ). }\end{array}$ & $\begin{array}{l}\text { Primary excavation } \\
\text { vehicle }\end{array}$ \\
\hline $\begin{array}{l}\text { IT28B integrated } \\
\text { tool carrier }\end{array}$ & $\begin{array}{l}\text { 23,(K)(N). Ib machine weight, outfitted with a } \\
\text { Balderson grip and grab end effector. Flywheel } \\
\text { hp 110. (see Figure 23). }\end{array}$ & $\begin{array}{l}\text { Alternate excavation } \\
\text { vehicle }\end{array}$ \\
\hline $\begin{array}{l}\text { EL_2(0)B hydraulic } \\
\text { cxcavator }\end{array}$ & $\begin{array}{l}\text { 52,0(0)-1b machine weight, outfitted with a } 1 \text { yd }^{3} \\
\text { hucket, reverse mounted to simulate a front } \\
\text { shovel configuration. Flywhed hp } 148 \text { (see } \\
\text { Figure 24). }\end{array}$ & $\begin{array}{l}\text { Alternate excavation } \\
\text { vehicle }\end{array}$ \\
\hline 93.5C rack loader & $\begin{array}{l}\text { 17.(K() -Ih machine weight, outfitted with a } \\
\text { multipurpose bucket (approximate } 1 \mathrm{yd}^{3} \text { ). } \\
\text { Flywheel hp } 80 \text { (see Figure 25). }\end{array}$ & $\begin{array}{l}\text { Alternate excavation } \\
\text { vehicle }\end{array}$ \\
\hline $\begin{array}{l}235 \mathrm{~B} \text { hydraulic } \\
\text { excavator }\end{array}$ & $\begin{array}{l}\text { 1(1)3,(KK)-lh machine weight, outfitted with a } \\
\text { Allied-Gator } 1,1(K) \text { ton shear. Flywheel hp } 250 \\
\text { (sec Figure 26). }\end{array}$ & $\begin{array}{l}\text { Shearing of large } \\
\text { objects }\end{array}$ \\
\hline $\begin{array}{l}1 T 28 B \text { integrated } \\
\text { tool carricr }\end{array}$ & $\begin{array}{l}23,(\text { KK)-Ih machine, outfitted with custom } \\
4 \times 4 \times 8 \text {-ft transport box attachment. Flywhed } \\
\text { hp } 110 \text { (see Figure } 27 \text { ). }\end{array}$ & $\begin{array}{l}\text { Transport and } \\
\text { dumping of } \\
\text { excavated waste }\end{array}$ \\
\hline
\end{tabular}




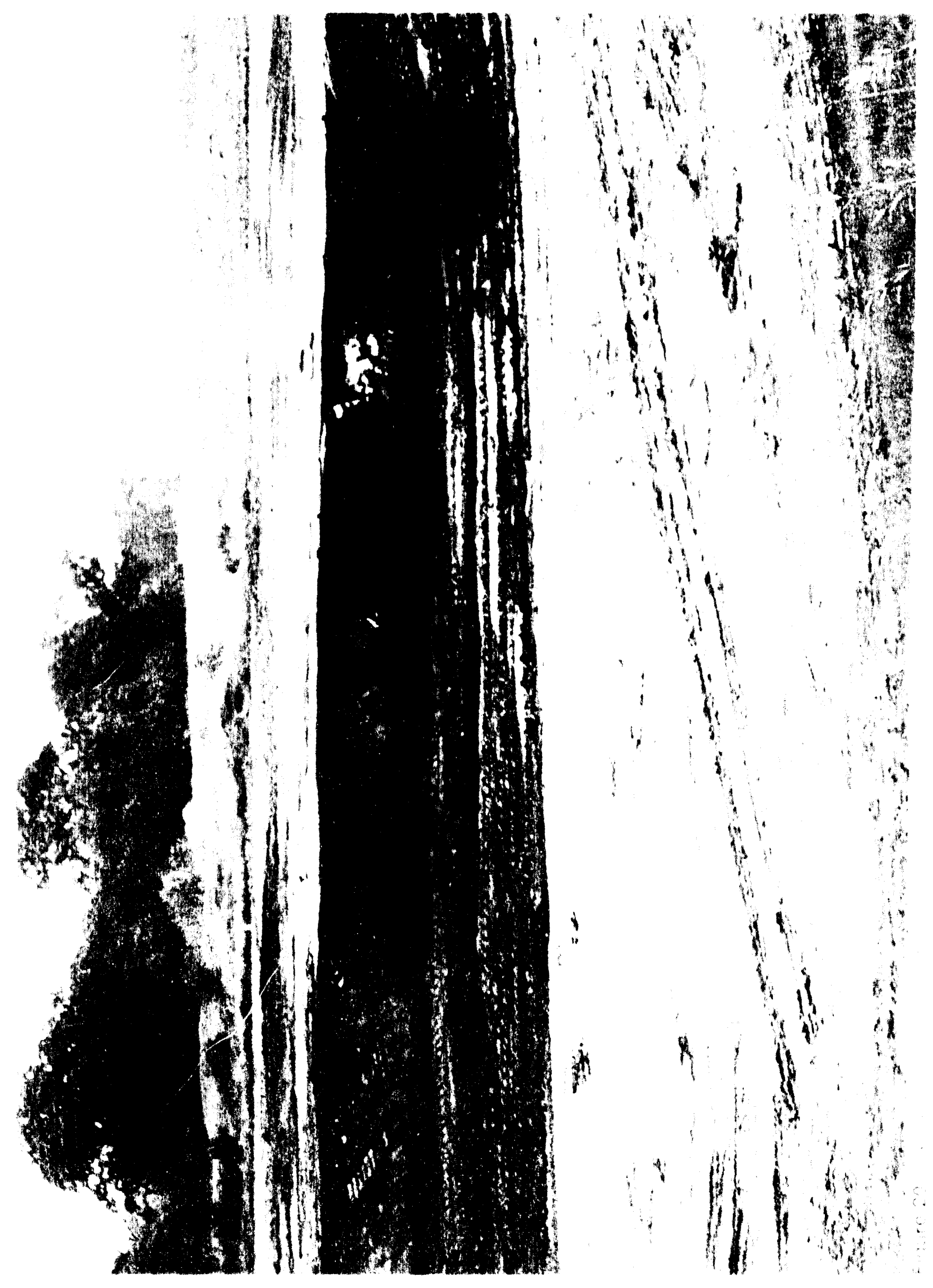




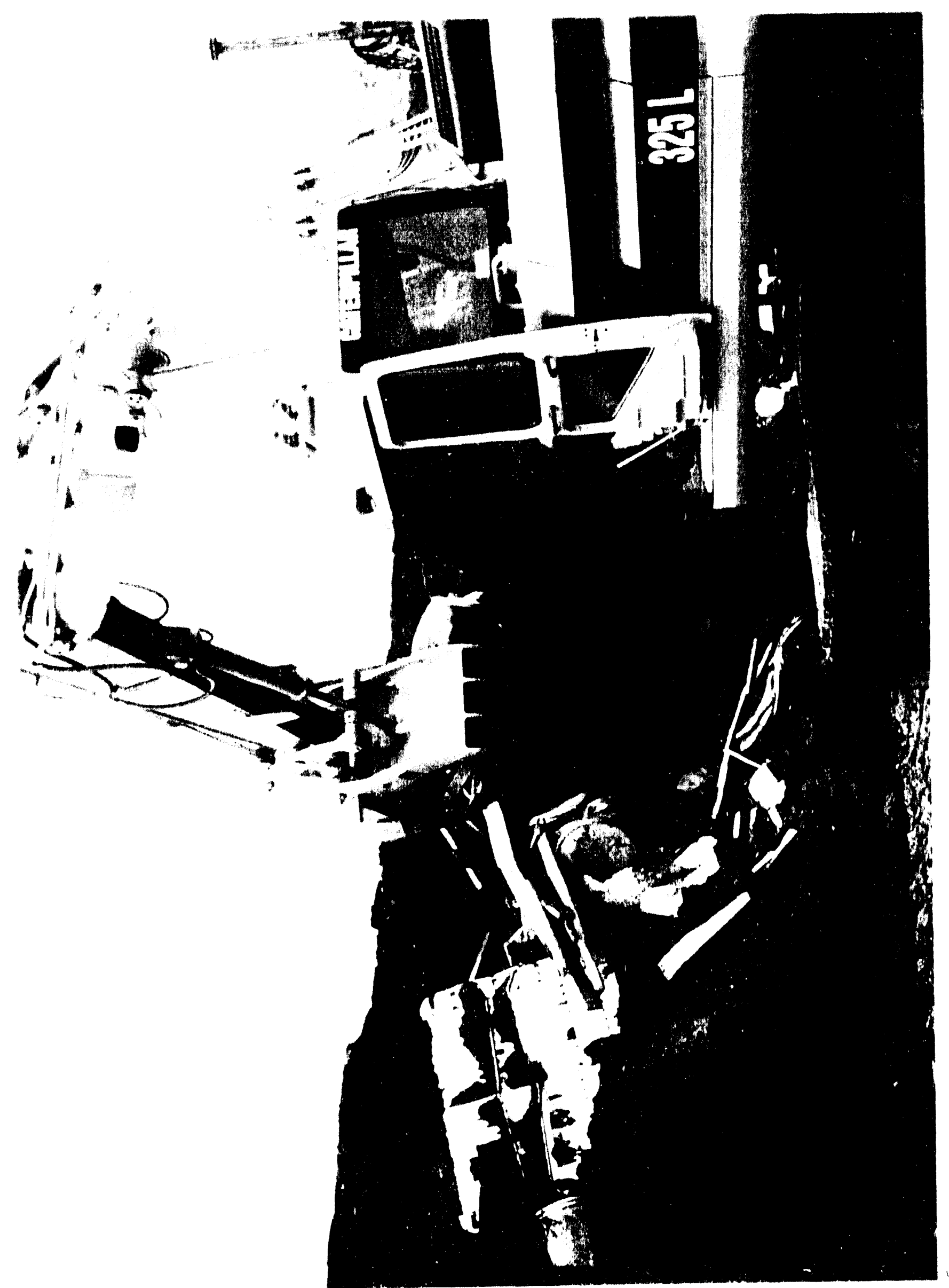




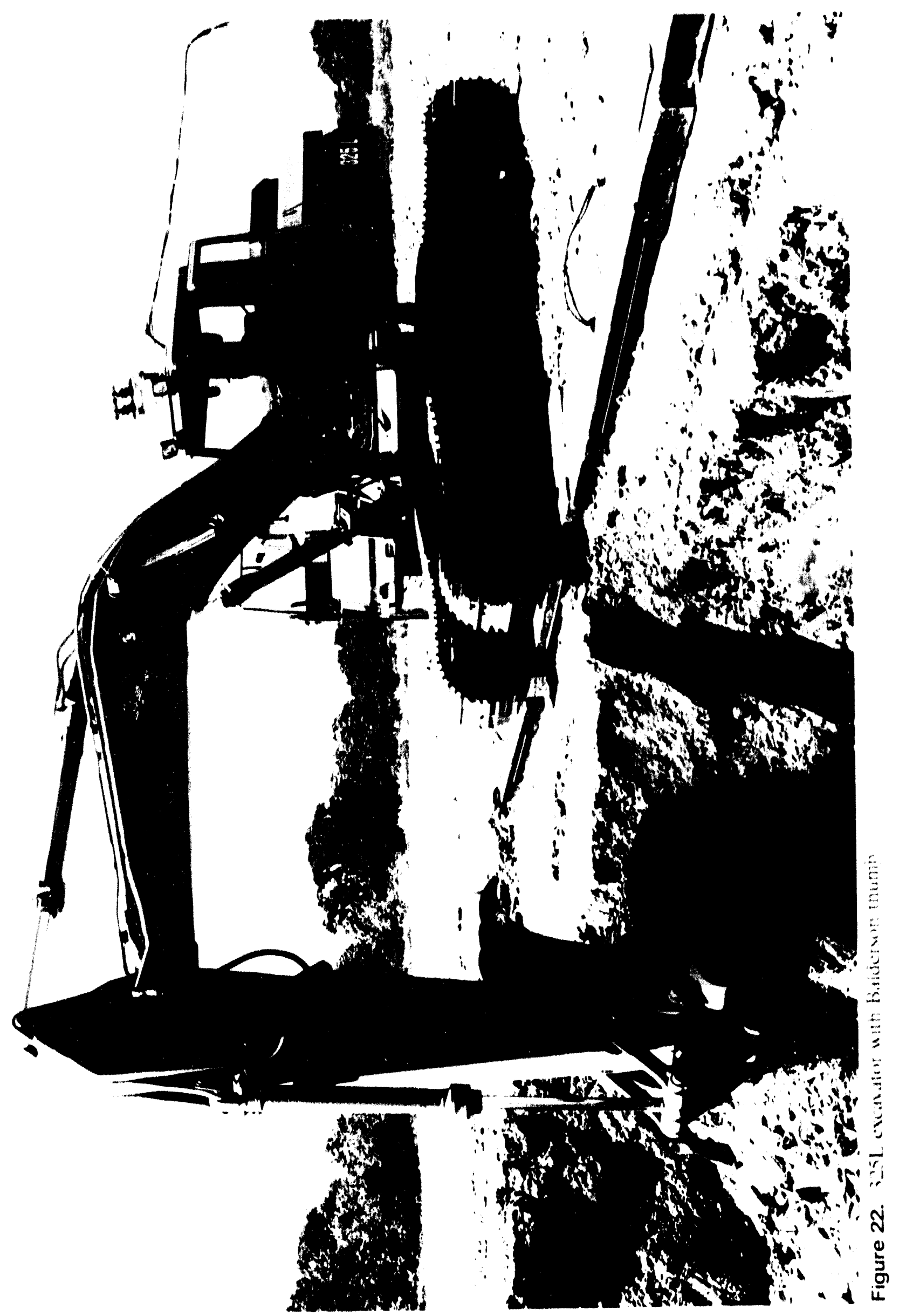




$$
-2
$$

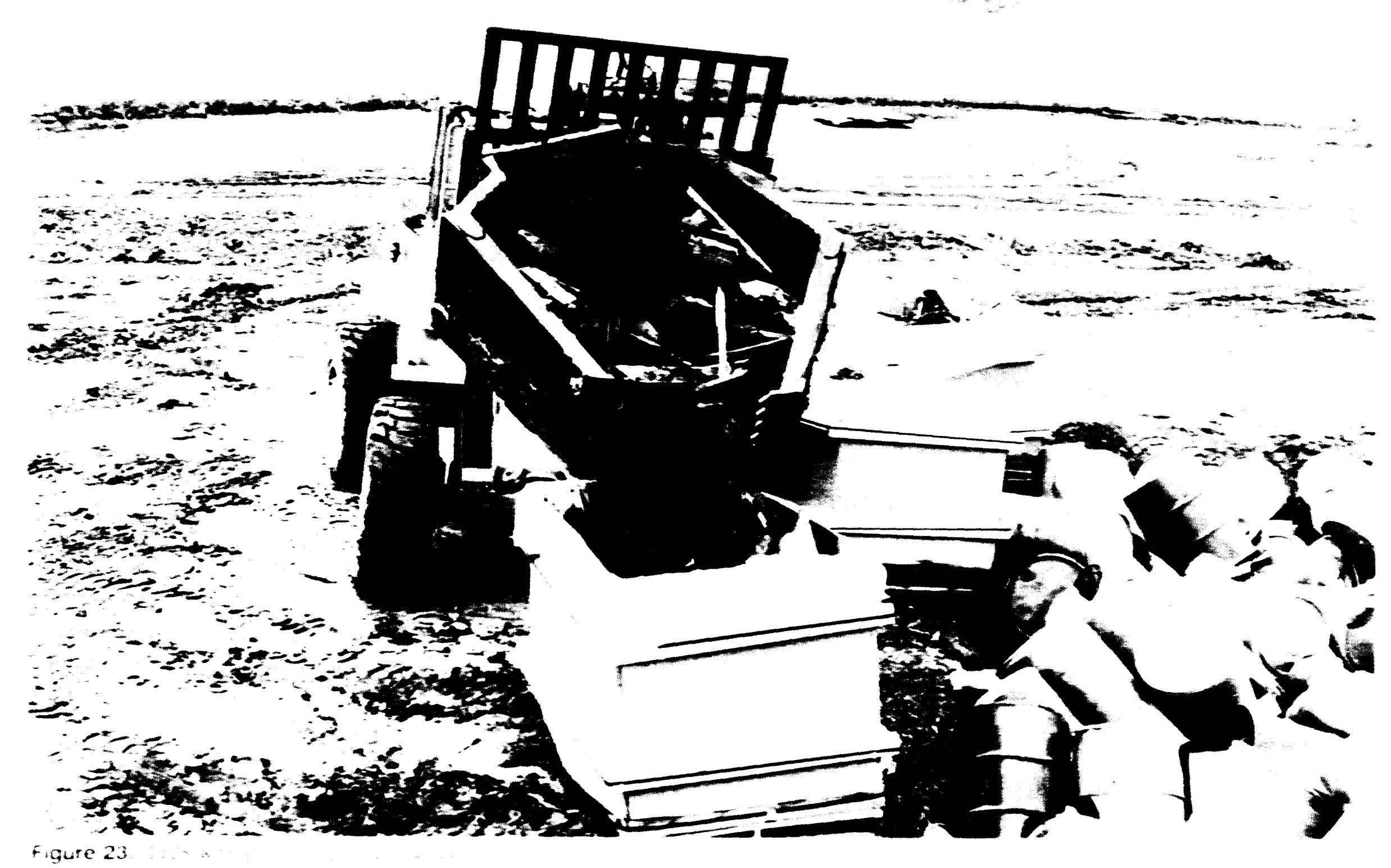




$$
\text { (1) }
$$

(1) $4-5)$ -

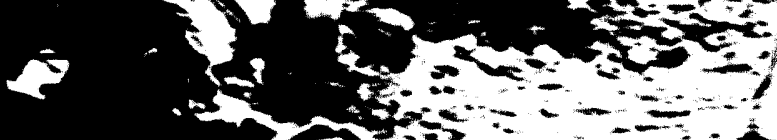

$-4$

\& $3=1$

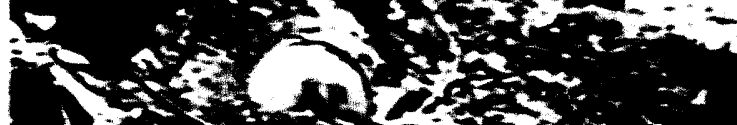

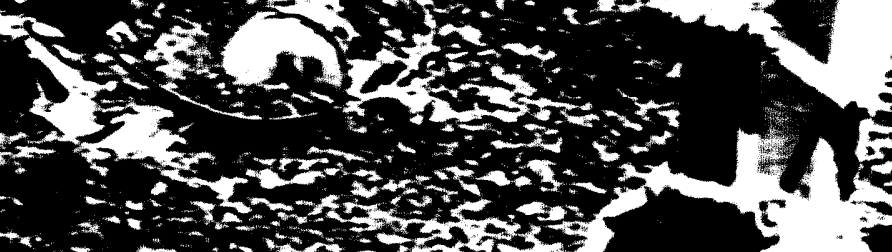

W 0

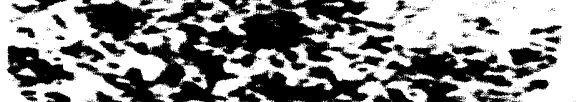

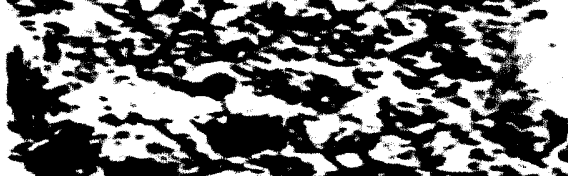
atsots Figute 2 d

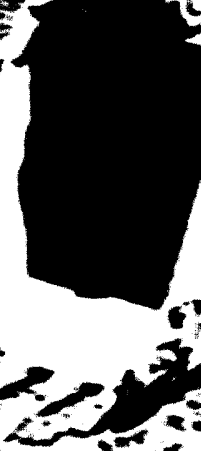

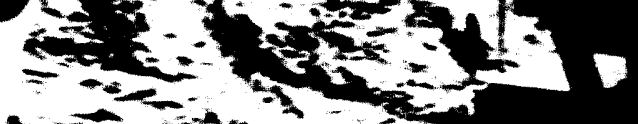
$x=2 x-4$

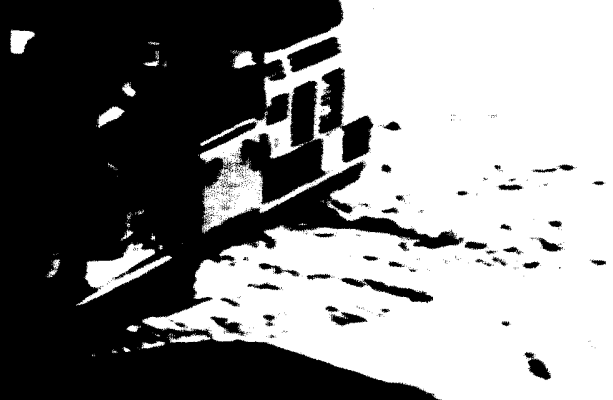
-2 - to

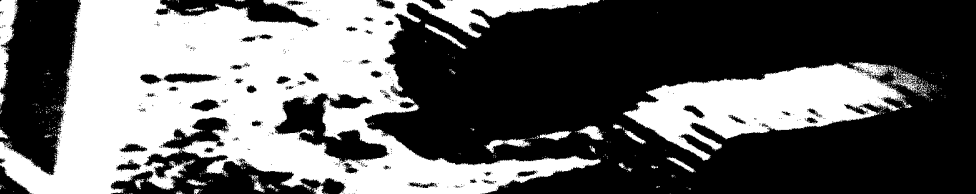

-

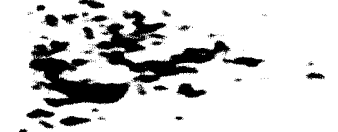
$2+=2:$ $x+2=$ 


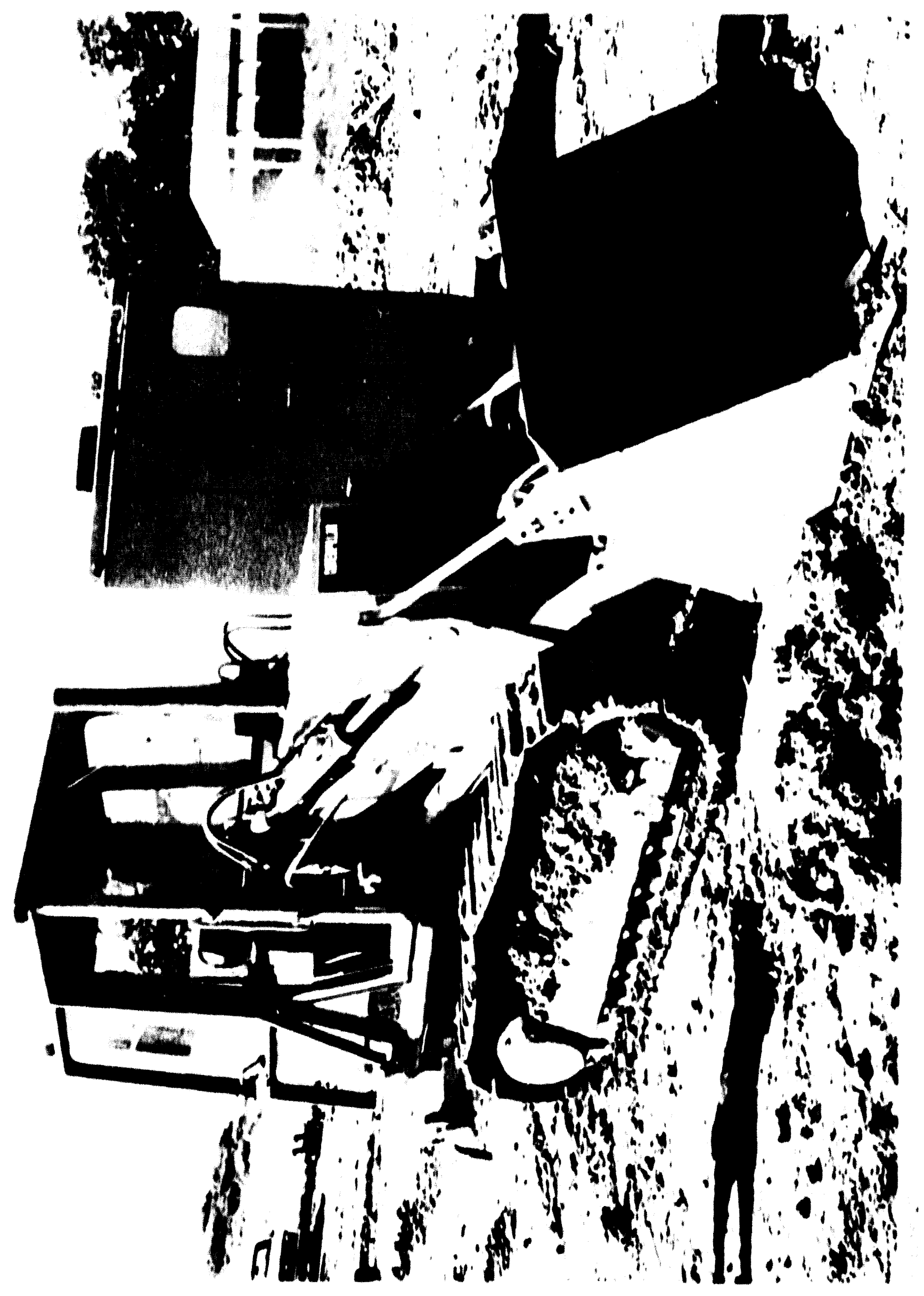




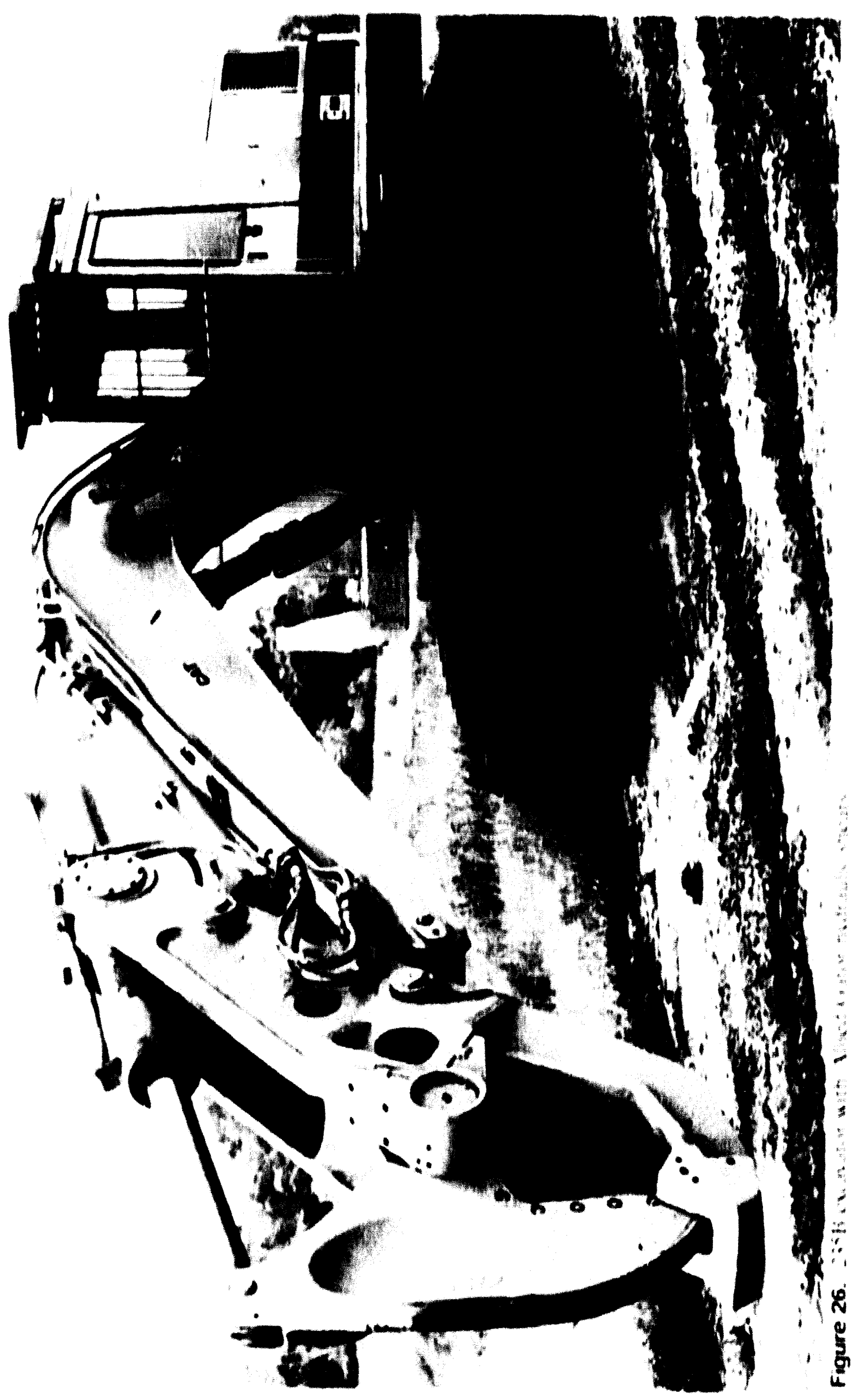




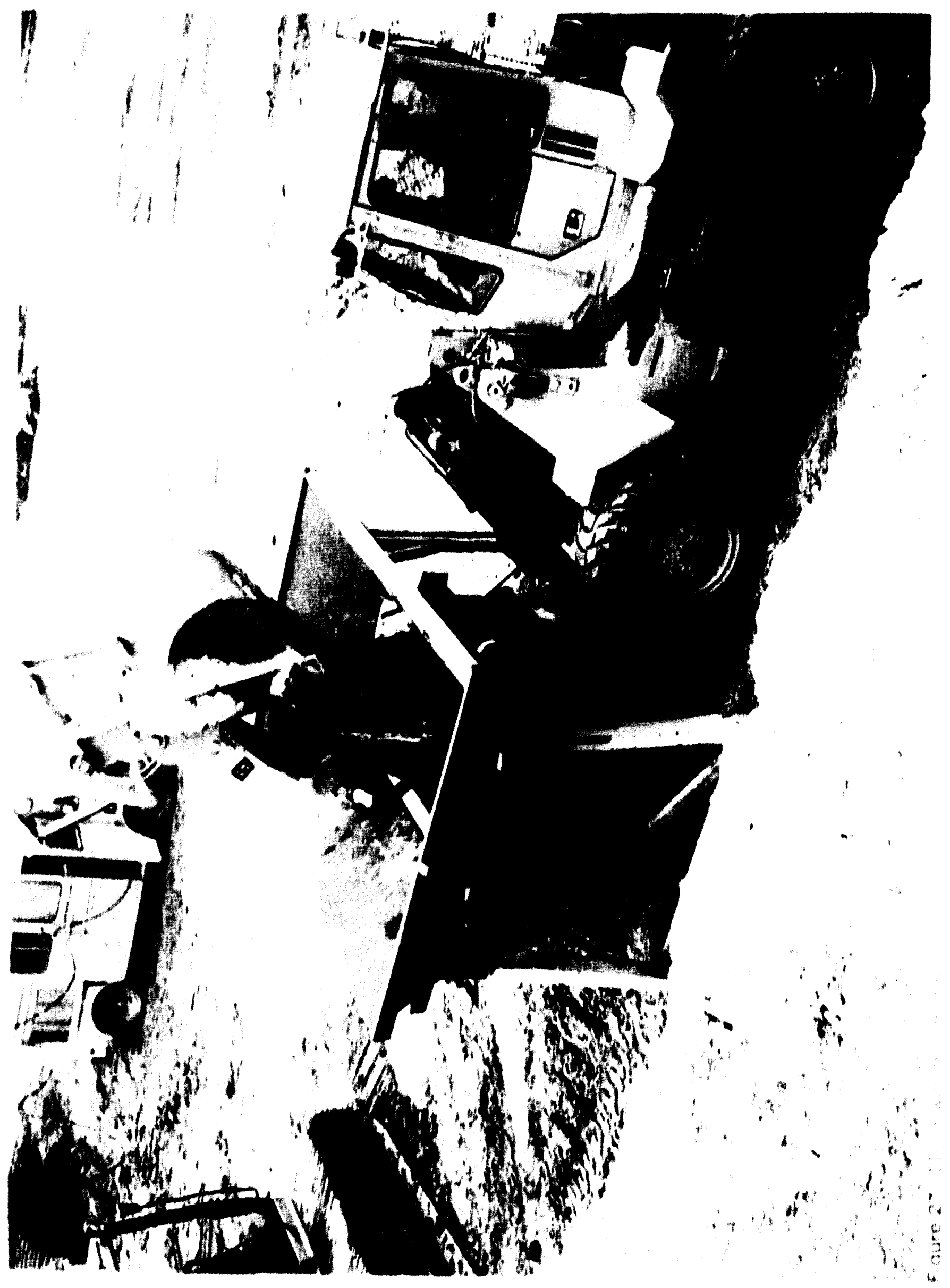


equipped with an Allied Gater Shear was positioned to the side for sizing large objects. The ITC28 was used 10 transport the $4 \times 4 \times 8$.ft hoxes of debris 10 the simulated waste storage area. Work progressed with the 3251 . for 3 hours and 15 minules at which time a total of $145 \mathrm{yd}^{3}$ of material had been removed. The entire first pass of the random dumped barrels and boxes cell, lirst pass of the soil berm. and small portion of the stacked harrels and boxes cell were removed. About six stecl heams and pipes were removed from the random cell as well as sections of cable and the b-fit cube. These large objects wete set 10 the side during the excavation process and later sized with the excavalur mounted sheirs (sece Figure 28). The sizing of the beams, cahle, and cube took about onehall hour. The 325l. with thumb worked extremely well 10 remove soil and debris and proved very dextcrous for mancuvering small and large pieces of metal and cable (sec Figure 29). The machine wis able to pluck 50) fl sections of cable from the random pit with ease, and the pipe and beams were removed with no trouble. The o.ft cube placed in the random ecll was also handled effectively (see figure 30). There was very minimal spillage lrom the digface to the funnel. During this segment of the test, probably no more than one quarler yard of material spilled trom the thumb, and most of this was during the dumping operation. Virtually all matcrial that wiss spilled was picked up by the thumb and hucked. Movemenl of the tracks an the 3251. from the helowgrade position was very limiled (i.c.,

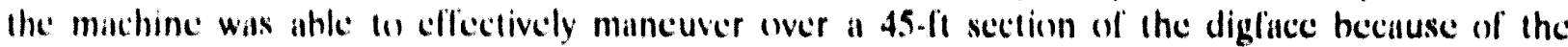
"reiach" of the bocem and stick). In over 3 hours of operation, the machine had to be slightly repositioned twice. Banding used on help stabiliee the hoxes presented a problem. The bands would dangle from the hucket (sece Figure 31), and this required selling the load down and attempling tor grab the lowse end into the huckel. This lechnique worked well hut had ow he repented several times li get the lowse ends.

Tueseday June \&-During the previous night it rained heavily and deposited nearly 1 -in. of water at the l:TC. The cold lest pit and surrounding area was muddy. The general work area was scraped wilh " motor gracker 10 remove a layer of mud, and work commeneed just affer 8:(K) a.m. The ITC28 oullilled with the Bilderson grip and grab was used. Work proceceded lrom the belowgrade position. The grip and grab had liair success with loose mulerial (debris that had fallen from the in situ digfuec). but was nol ellective with the in situ diglace (sece Figure 32). Work continued for one-hall hour (the list 15 minules in heavy rains) and was then stopped hecause of weather (severe thunderstorm and tornatdo threat). About $15 \mathrm{yd}$ of material was removed during this time by the grip and grab.

Wedneseday Junc y lithe work area had dried out considering the amount of rain during the last 36 hours. Work resumed al $8:(X)$ a.m. from the belowgrade position in the stacked harrels and boxes cell. The 3251. Wils used again with results similar 10 those described for June 7. The excavator worked ler 1 hour and 4.5 minules and removed $(x)$ yd ${ }^{3}$ af malerial. During this time, all of the lirst pass of the stacked cell and a small portion of the second pass were removed. A 93.5 track loader was tested nexl. At 10:18) a.m. Work starled on a pile of loose dehris (track londer would not be elfective for in silu waste) and procededed to remove and load dehris lor 1 hour (sece Figure 3.3). ihoul $3.5 \mathrm{yd}^{3}$ of malcrial was remosed in this lime. The track loader would not be very effective working with large objects or with cable becaluse of the limited end elfecter versatility. The handing posed some problems fior the loader, but with carcelul operation, banding protruding from the bucket was minimized. Unloading the multipurpose bucket on the track loader was difficule because it was hard I1) see where the huckel was with respect to the funnel. At 11:(K) a.m. the ITC28, litled with a grip and grab end effector, was tricel again. This teol was used to clean up a small amount of debris and soil left in the stacked cell (second pass) and remove soil from the separation berm (also the second pass). Il performed similar to the previous day, although when working in soil (the separation berm), 


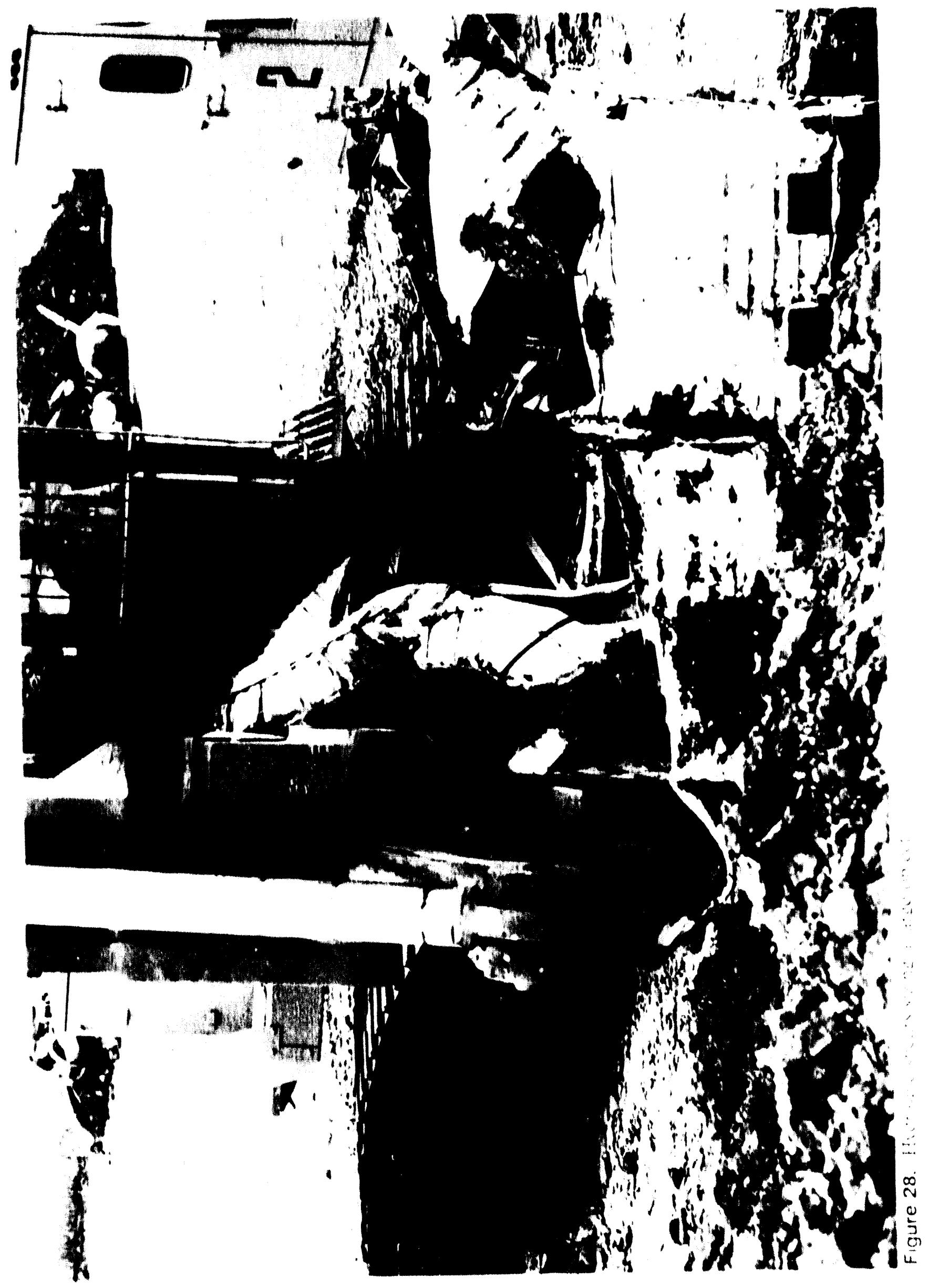




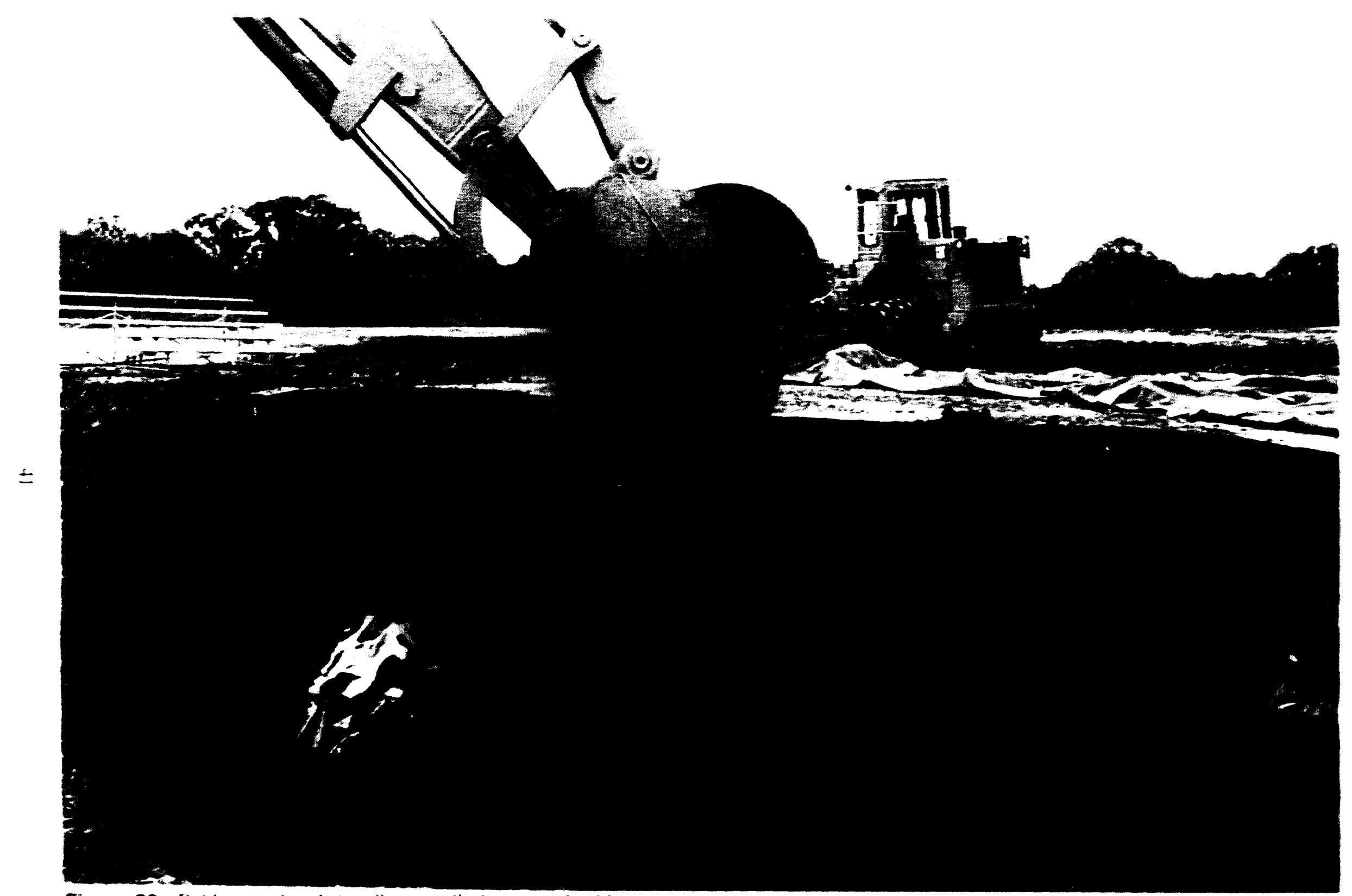

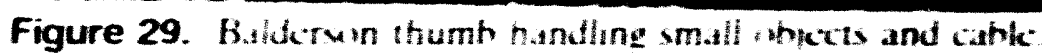




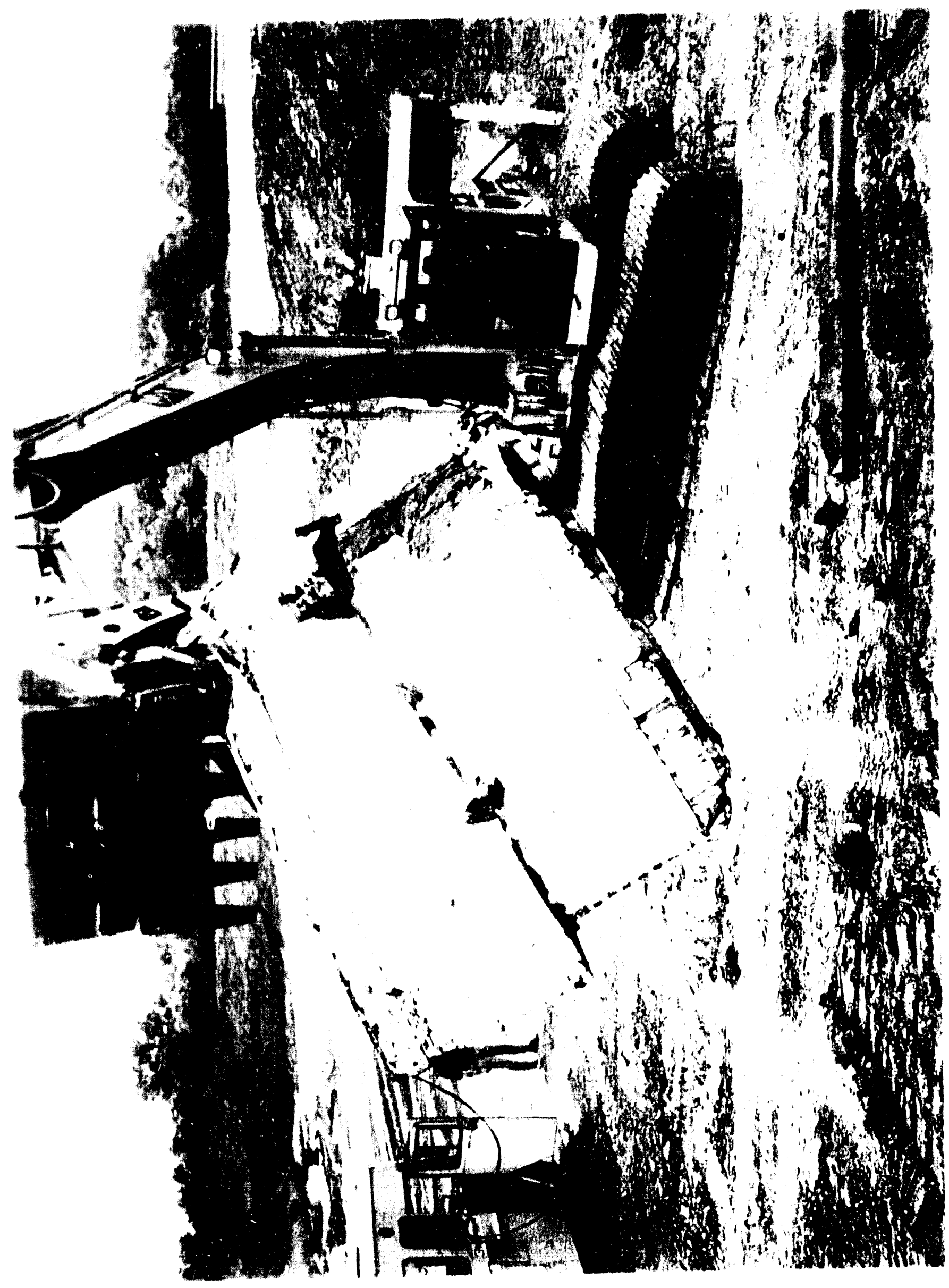




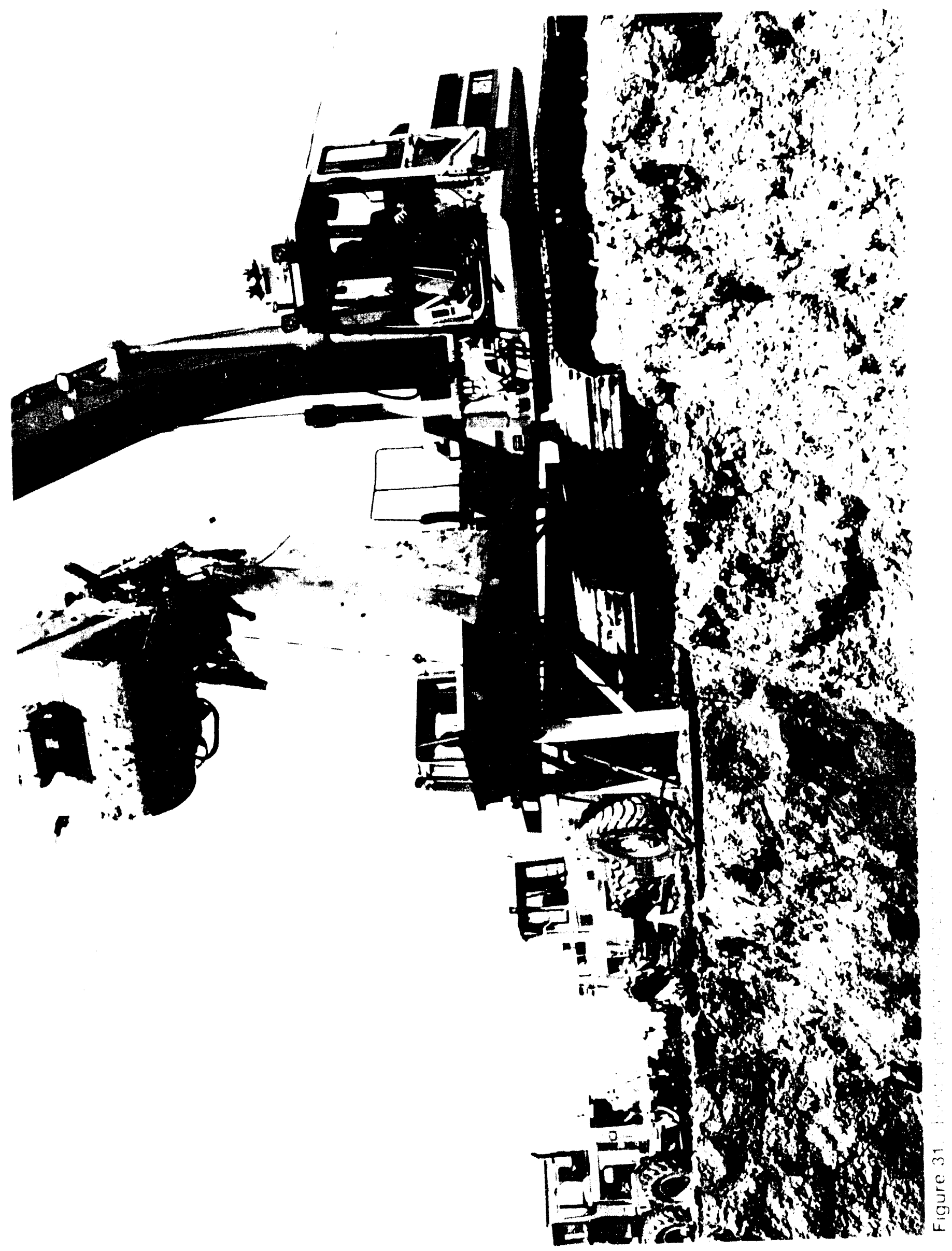




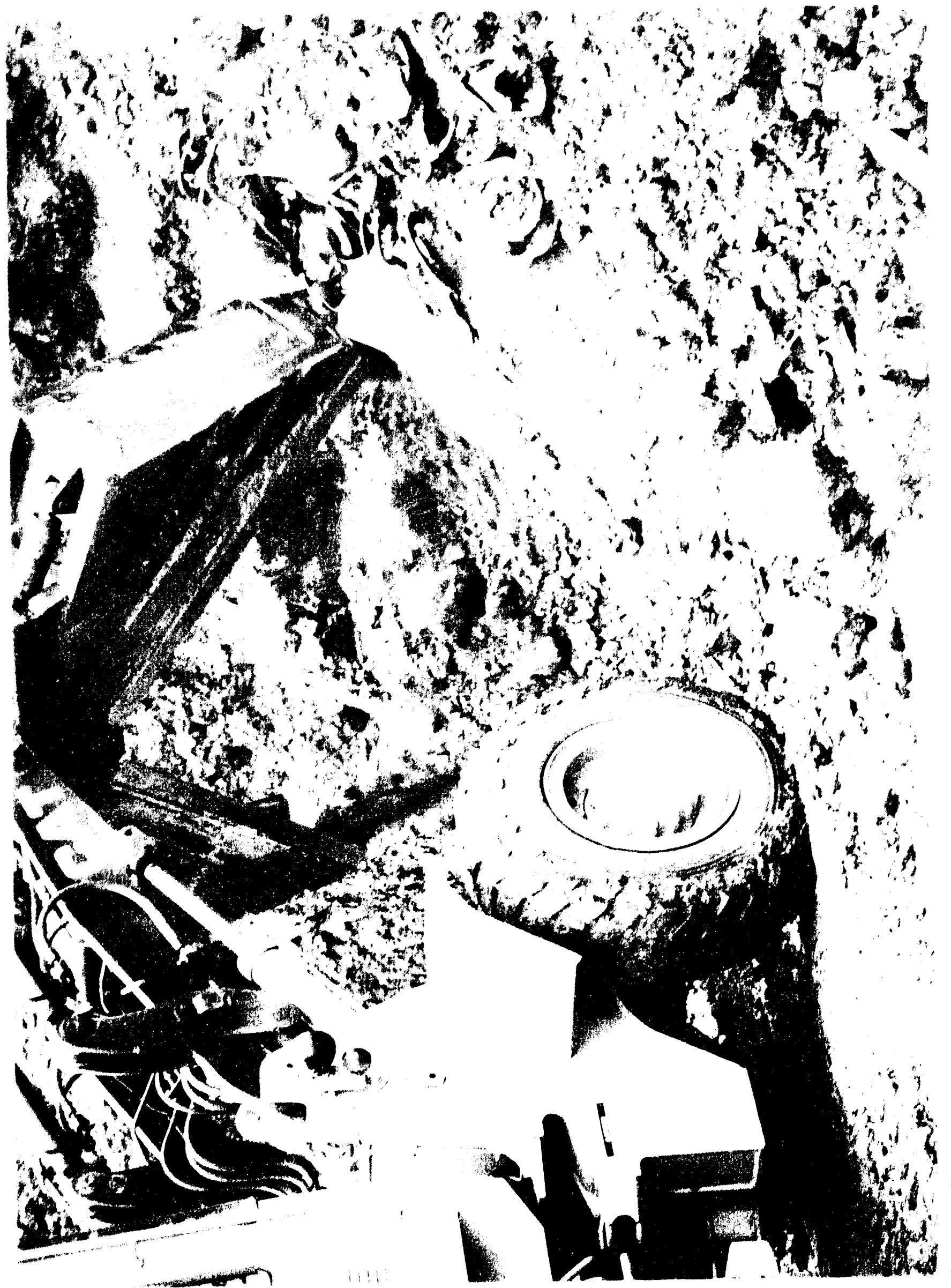




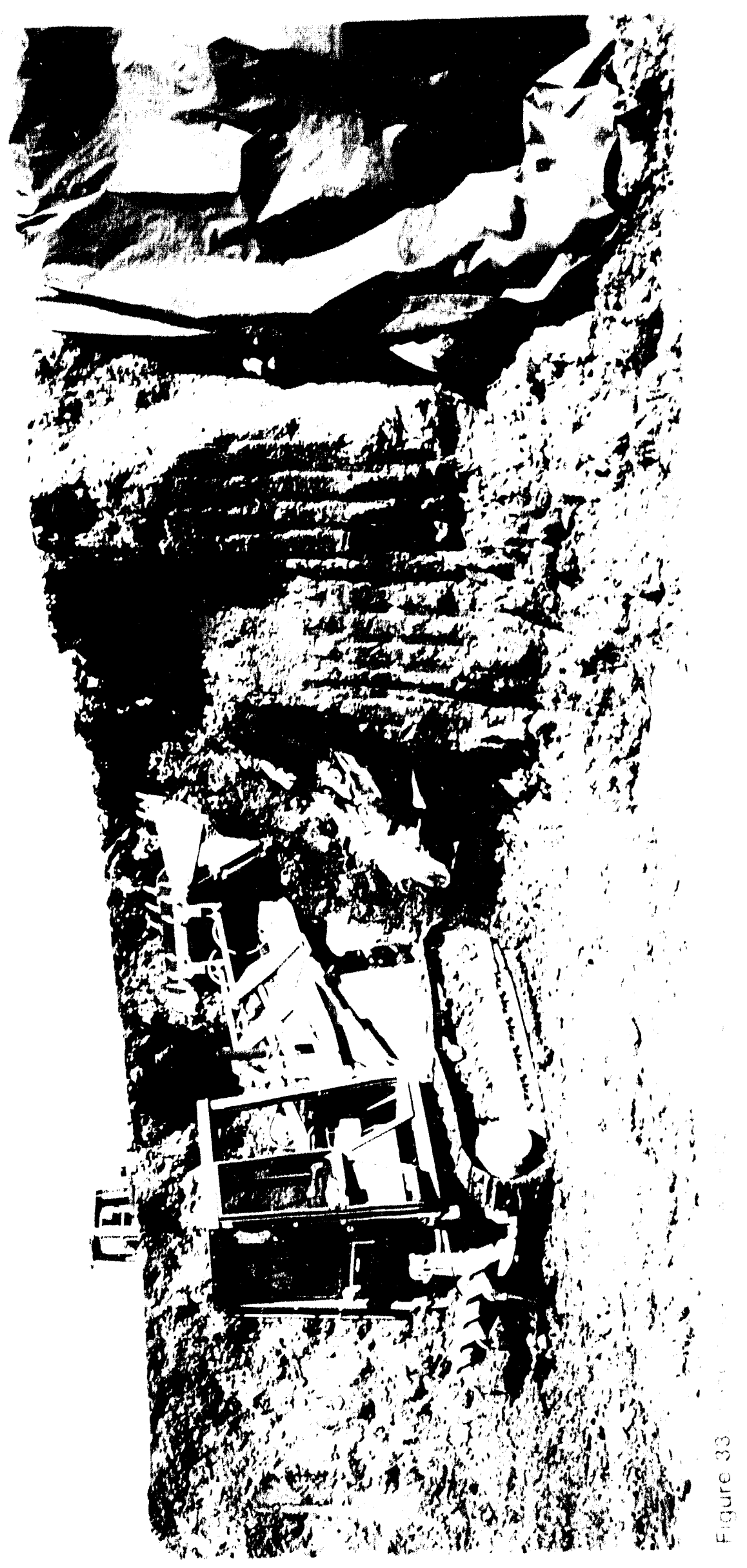


the grip and grab wass very ellective. Forty cubic yards of material were removed with the grip and grab in 1 hour. At 1:(K) p.m. an EL2(K)B excavalor with front shovel was used for the remainder of the second pass (sec Figure 34). Work starled from the belowgrade position in the stacked boxes and drums cell, continued through the soil berm, and linished in the random zone. The front shovel functioned well; however, there were a few problems with loose banding and cable dangling from the bucket. The front shovel was capable of removing in situ matcrial. A total of 200 ) yd of material was excavated in 4 hours. No beams or pipes were encountered; however, the EL2(x)B was able to remove a large storage lank and the machine tool by balancing these large objects on the bucket (see Figure 35). The 3251. exeavator was used again from the belowgrade position to complete the second pass of the random zone. The $325 \mathrm{~L}$. was used for 40 minutes and removed about 40 ) $\mathrm{yd}^{3}$ of material. The thumb was also used to handle the previously extracted lank and machine tool to test dexterity. Another 20 minutes were used to size these large ohjects with the shears (see Figure 36). Al this point, approximately $55 \%$ of the pit had been excavated (a small portion of pass three was removed during the excavation of the second pass because the diglace was not kept quite vertical).

Thursday June 10-Preparations to excavale with the 3251. and thumb lrom the abovegrade position for the third pass were made. The funnel was placed abovegrade also, and all dumping oceurred from this position as opposed to belowgrade as originally called for in the lest plan. The reason was a safety concern. Loading from abovegrade to belowgrade requires awkward positioning of the funnel with respect to the excavator hoom, and if there was a digface collapse, the operator of the ITC28 would be in danger. Timber mats, to help disperse the weight of the excavator, were placed on top of the cells. The third pass was starled with the 325L excavalor from the abovegrade position (see Figure 37) at the stacked ecell and worked for about 2 1/2 hours until the stacked section of the pit was completed. Next, the third pass of the dirt berm from abovegrade and linally the third pass of the random eell were removed. Although operator visibility was not as good from abovegrade, production was close to that of helowgrade.

Friday Junc 11-Excavation work ceased at the pit until June 15. On this date, the remainder of the pit would be excavated as part of a demonstration for a number of visitors planning 6 witness the retricval activity in the field. CAT removed about two-thirds of the previously excavated simulated debris to an approved landiill. Four 2()-yd trucks were loaded during the day and approximately 20) loads of material were removed from the job site (see Figure 38). Each load of material was weighed at the site (by a portable truck scale, sec Figure 39) and the information recorded. As material was removed from the pit, it was segregated into three piles, one for each of the eells. Loading and weighing of material wats performed to determine the gross weight of each of the cells.

Tuesday June 15-A number of visiturs from the U. S. Department of Energy Idaho Operations Oflice (DOE-ID), EG\&G Idaho, CAT, and Martin Marietta attended the demonstration on this date. It was decided to excavate half of the fourth pass from the belowgrade position and half from abovegrade to exhibit the versatility of the $325 \mathrm{~L}$ excavator. The $325 \mathrm{~L}$ was positioned belowgrade at the random cell to start. The demonstration started at about 8:45 a.m. until 12:(K) p.m. during which time $160 \mathrm{yd}^{3}$ of material were removed. Several pipes, beams, and cable were also removed and placed to the side for sizing. A pickup truck bed was also extracted and later sized. There were no particular difficulties working in this side of the pit. Production remained fairly consistent with rates observed for other days (about $5\left(\mathrm{yd}^{3} / \mathrm{h}\right.$ (our). During this phase of the demonstration, a total of $21 / 2$ hours were used for retrieval, and one-half hour for sizing. At about 1:00) p.m., work resumed from the abovegrade position. The soil berm and stacked eell were retrieved from abovegrade. A total 
-

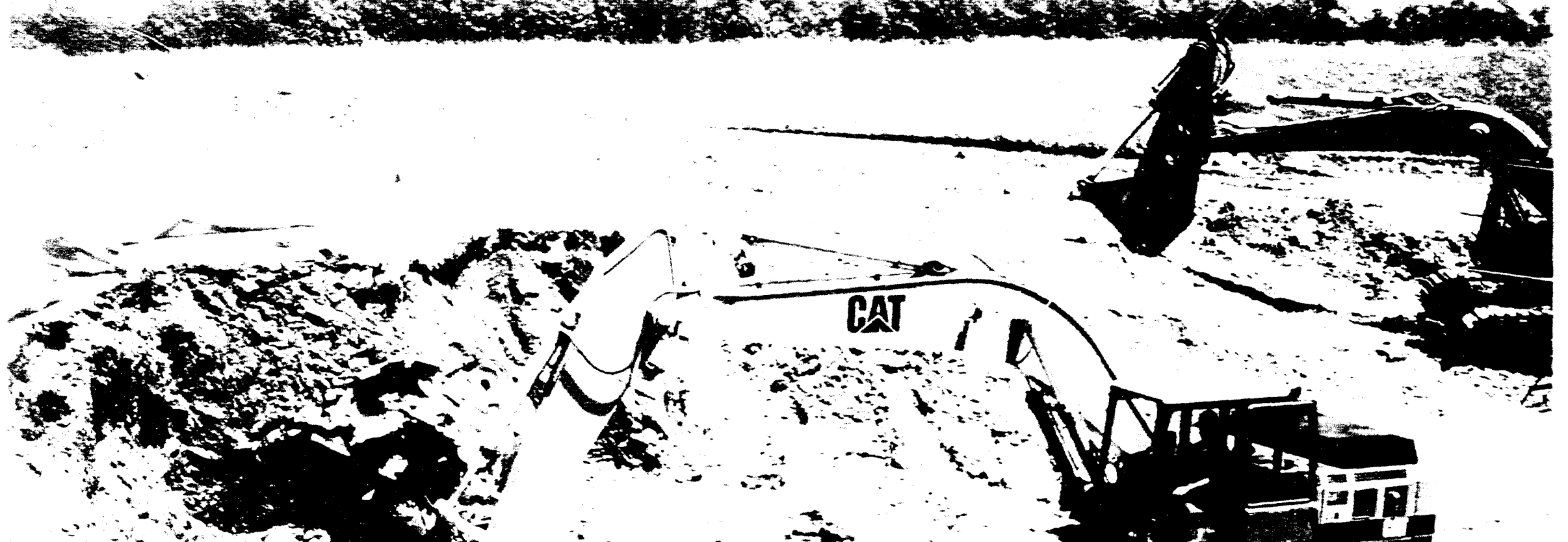

$+\infty$

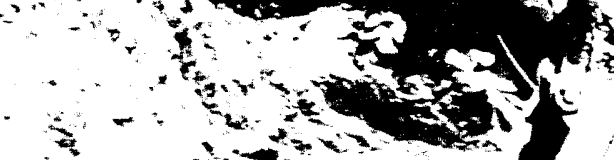

$=2+2$

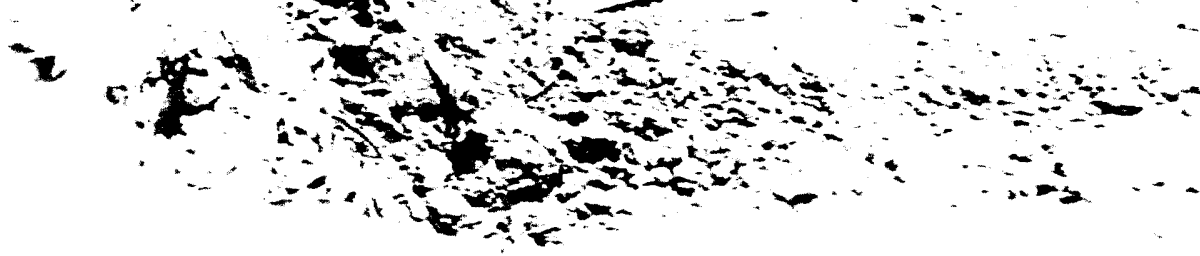

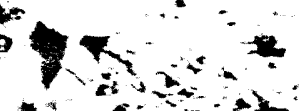

$\rightarrow$

$4-2+3=-2=$
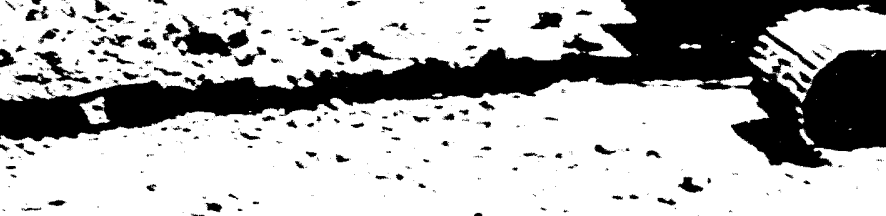

$x$

$=4$
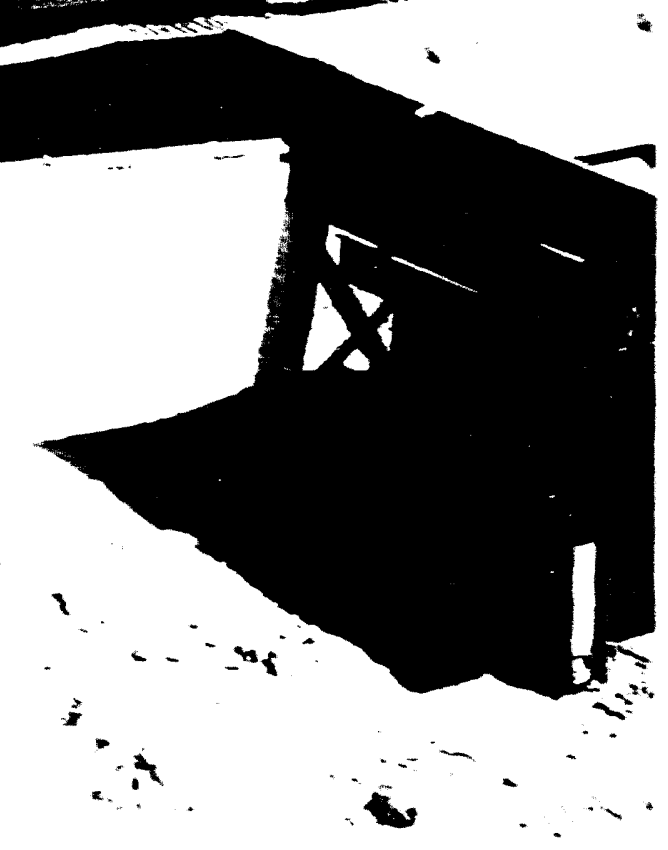


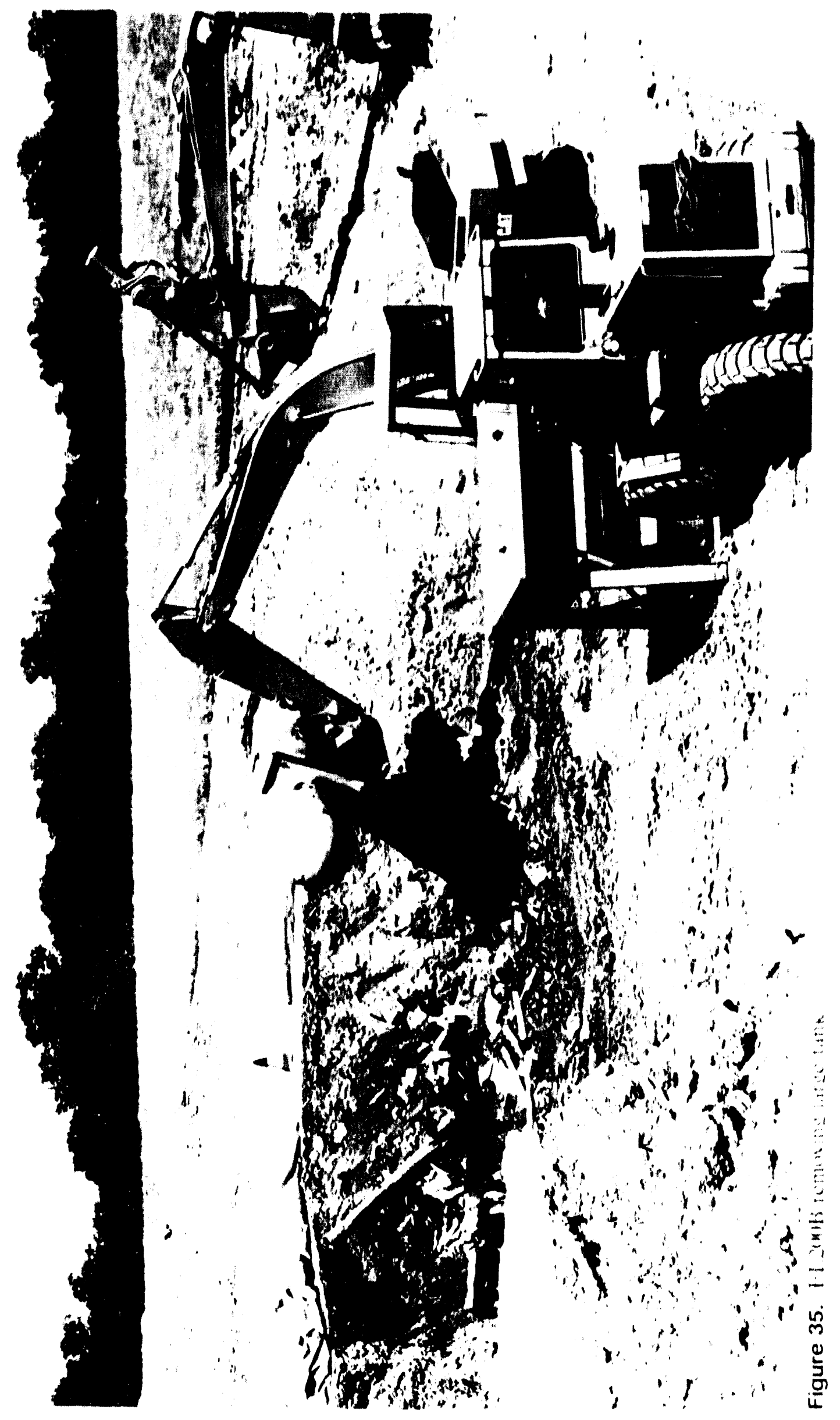




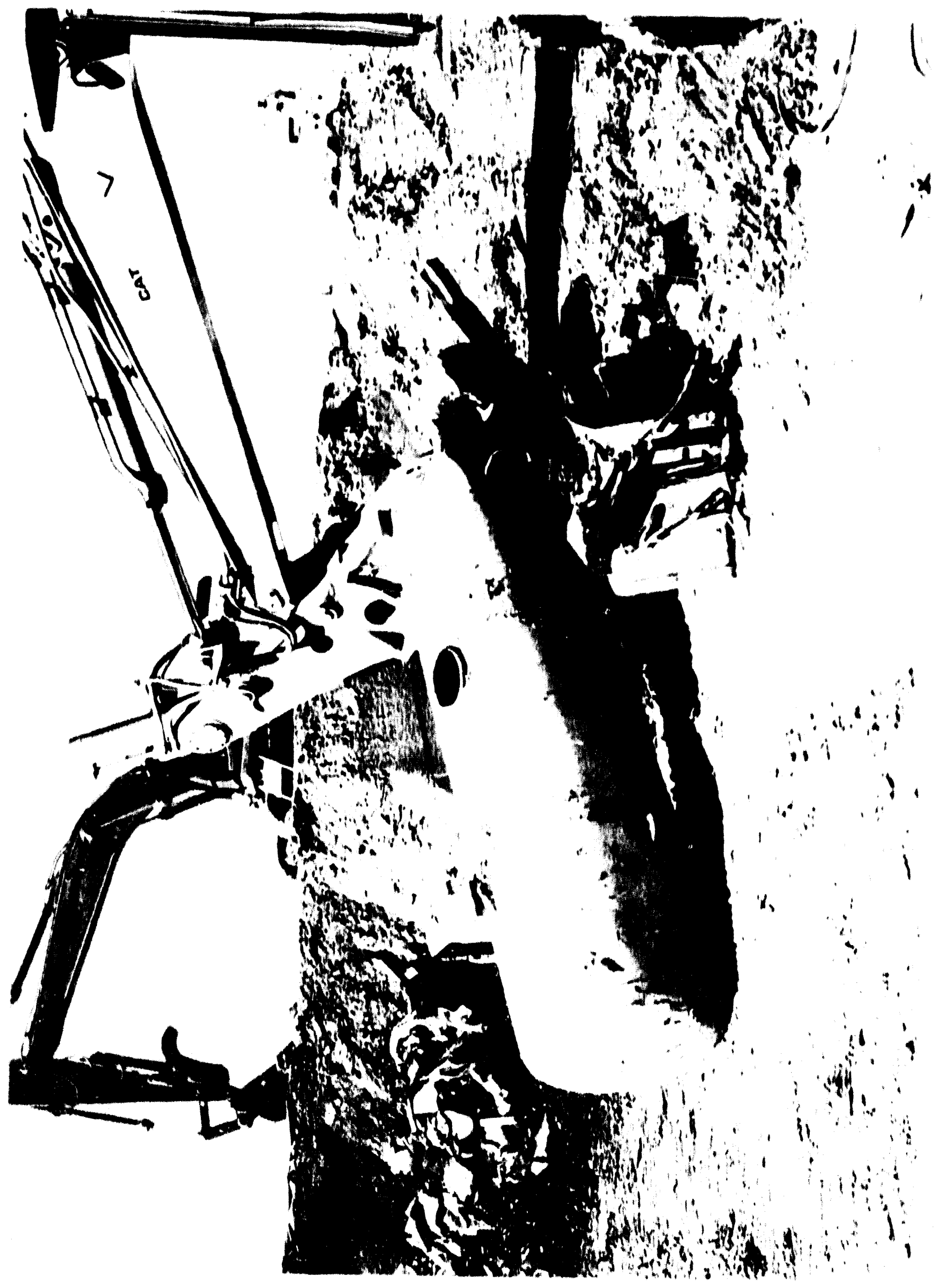




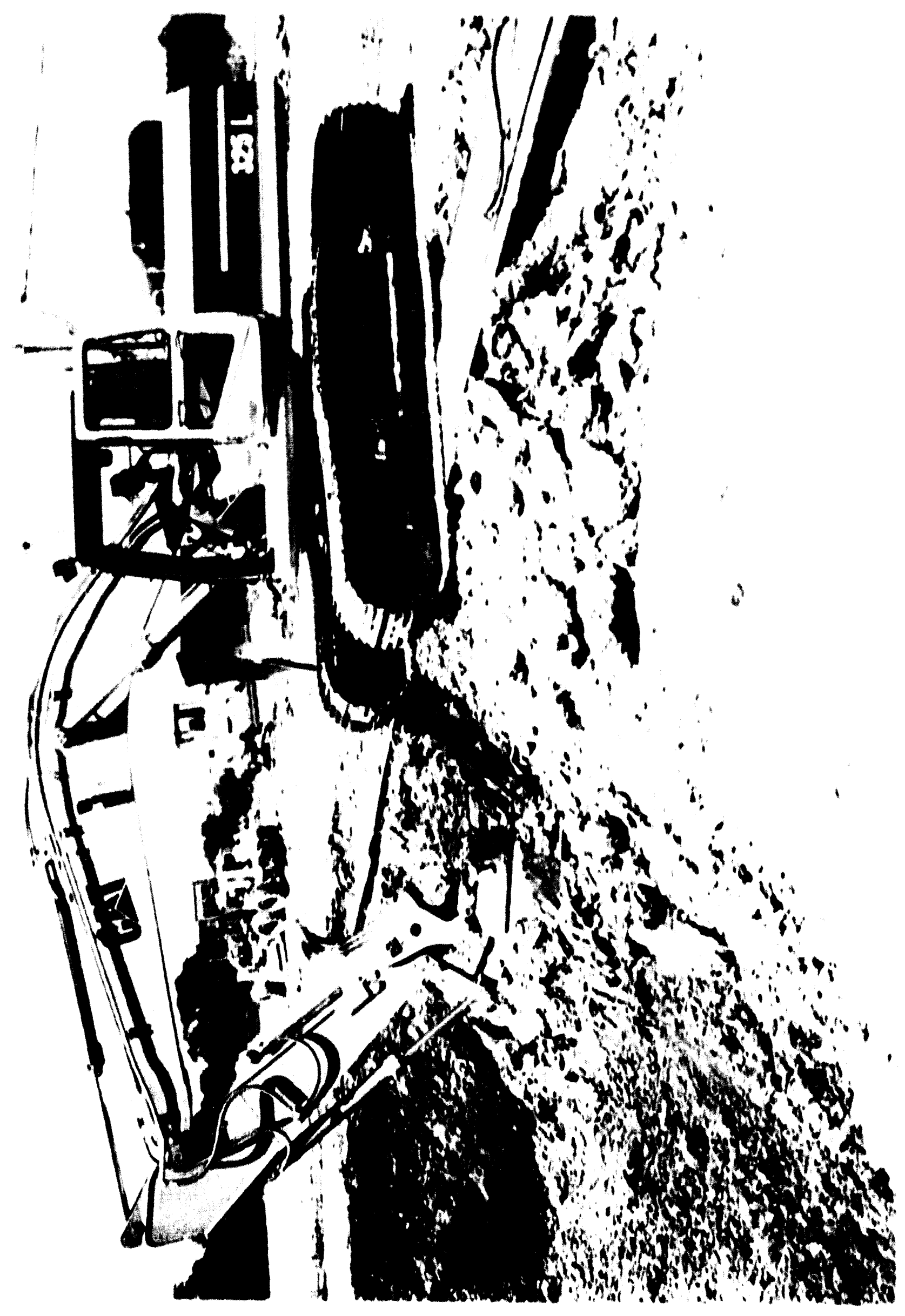




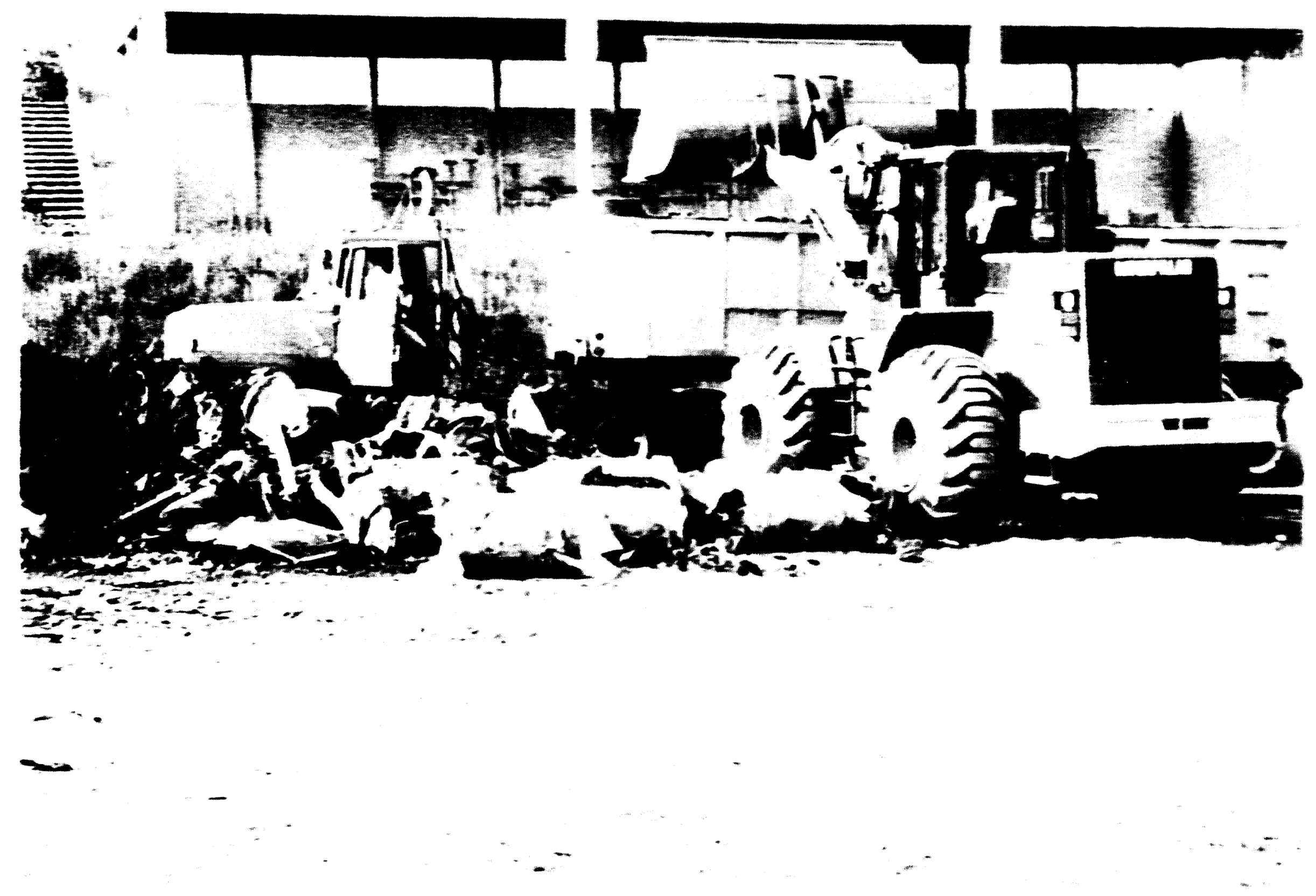




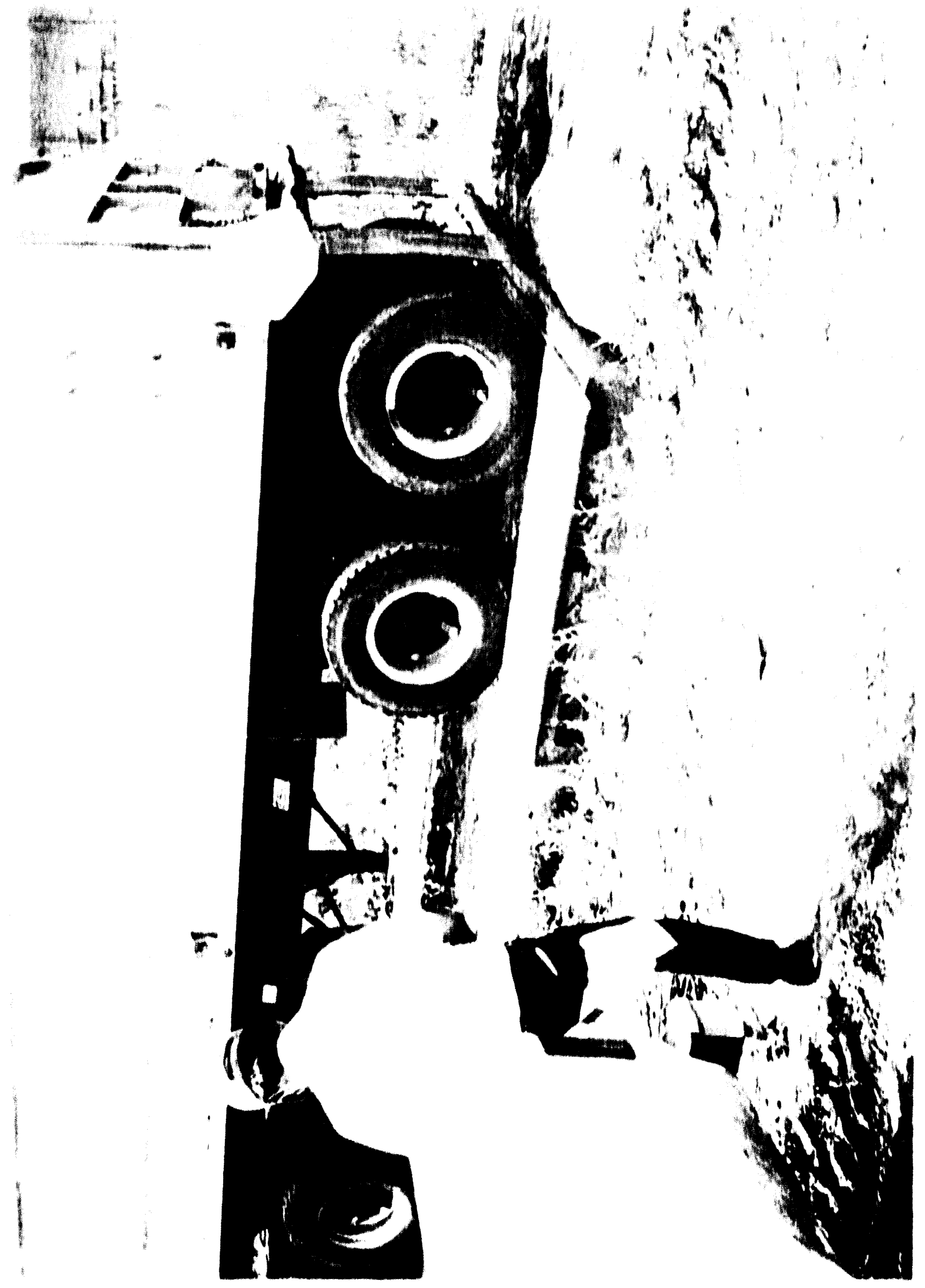


of l(M) yd' of malcrial were retrieved in 2 hours and 15 minules (again mainlaining approximately 50

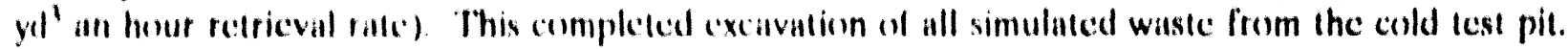

Wedncaday June 16-The remaining previously excavalted simulated waste was hauled offsite to a landfill.

Thuraday June 17-The cold tesl pit was reclaimed with clean fill matcrial, and the area was graded and contoured lo its coriginal shape. No debris was left in the area, and the site was left in an "as found or beller" condition.

Table 3 indicalles the passes, sections of the pit, and equipment used for waste retrieval during cich pass.

\subsubsection{Commentary on Excavation, Handling, and Dumping of Waste}

One operallot wiss used for waste retricval and sizing work. Matcrial that required sizing was remened from the digliace and placed off to the side where the shear could perform sizing operations. This allowed the 3251. 10 exciavale, and it was not necessary to position the 2.35 at the digface. Inslend, the excavalor would remove a large object, place it to the side, and continue working. Even when an item was decply huried in the pit. the excavator would continue working around the object

Table 3. Equipment used during excivition of cold test pit.

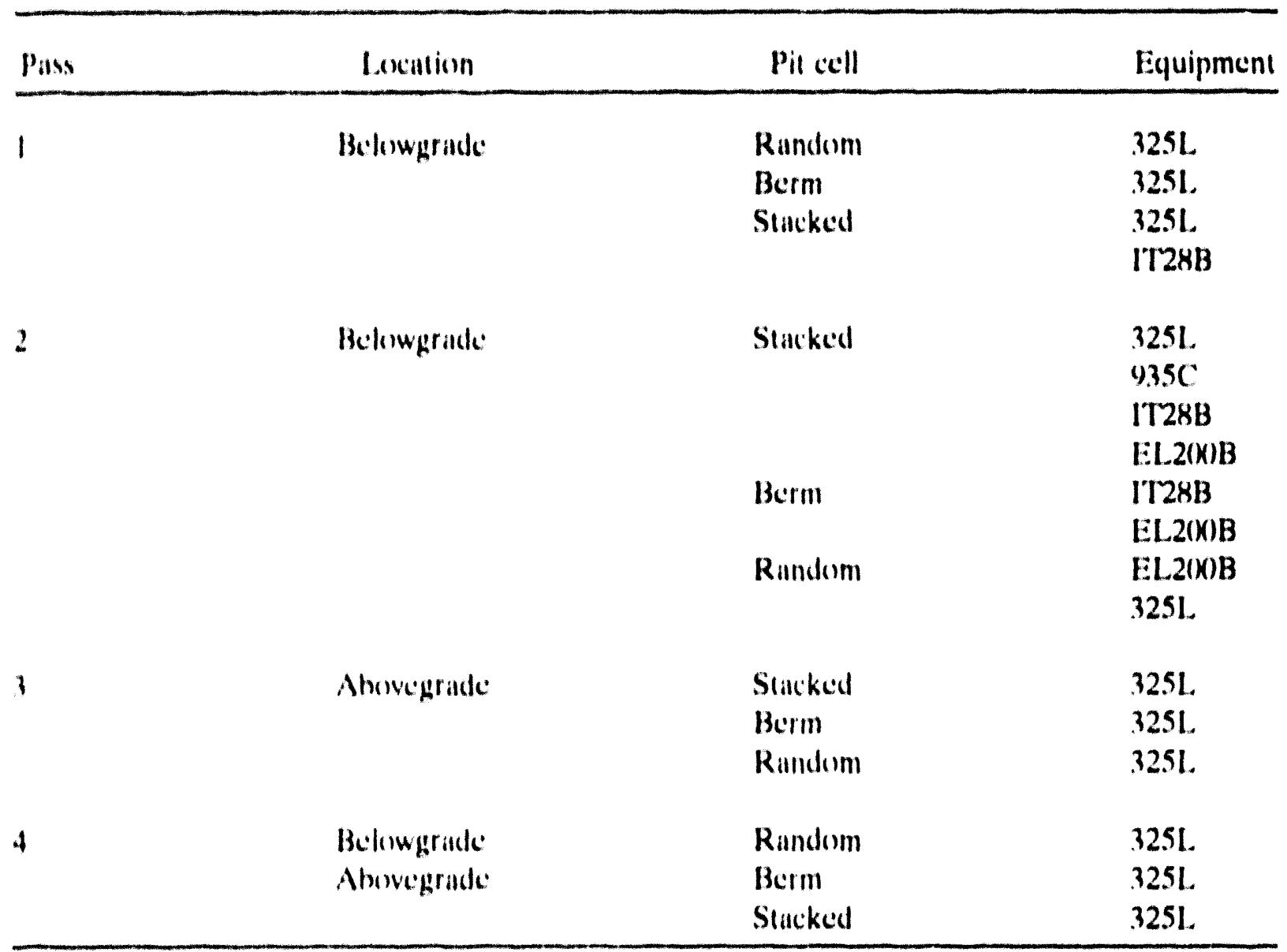


until it was able to remove it without having the shear move into the immediate area. Once the mutcrials requiring sizing had heen cut into small enough pieces, the excavator would pick up the debris and placed it in a storage box lor transport to the waste piles. This scenario was repeated for all of the large objects in the cold lest pit.

Handling of large or difficult to handle objects was performed most easily with the $325 \mathrm{~L}$. When encountering a cable, the operator was able lo grasp it between the bucket teeth and thumb and pull it out of the pit in one piece. Two methods of disposal were then demonstrated with the cable; the excavator placed the cable off to the side where the shear would cut it into pieces to fit into the hopper, or the excavator would coil it so that it could be picked up with the bucket and thumb (without dragging on the ground surface) and placed directly in a storage box.

During excavation, many of the cardboard containers breached. This created a heterogeneous mix of soil and waste (see Figure 40). After extraction from the digface, the waste was deposited directly through a funnel (to help focus the material) into a storage box (sec Figure 41). Drums that were filled with concrete were the heaviest of the waste forms (about $7(0) \mathrm{lb}$ each) and, if not placed carefully in the hopper, would land heavily and shake the IT28. The retrieval operator found that he was able 10 more completely lill the hopper if he filled it evenly with each bucket.

Five different equipment configurations were investigated during the course of the test. As shown in Table 3, four of the configurations were belowgrade (from the pit floor), and the remaining case was from abovegrade. Three of the four helowgrade cases involved an end effector that fills fiom the front (the IT28 with grip and grab. 935, and EL2ON) with reversed bucket), making them unsuited for abovegrade operation. Of the four belowgrade cases, the 325L backhoe and EL2(X) reversed bucket (o) simulate front shovel performed equally well. They each removed material from the pit at an average rate of about $50 \mathrm{yd}^{3} / \mathrm{h}$ (our and were able to handle large objects; however, the $325 \mathrm{~L}$ with thumb was more versatile working with large and difficult to grab objects such as cable. The other (wo pieces of equipment, the 935 track loader and IT28 with grip and grab, were not well suited to the operation for different reasons. The 9.35 was not a large enough machine to effectively dig into the pitface. It also did not have the vertical reach necessary to dig from the top of the pitface. Also, the multipurpose bucket end effector on the 935 is designed to handle relatively loose material. not in situ debris. The IT28 with grip and grab was not able to dig into compacted, well consolidated material. Although it performed well in loose material, the grip and grab could not generate the necessary forces to break loose in situ soil and waste. Additionally, the design of the grip and grab end effector resulted in difficulty dumping into the hopper without spilling.

Comparing abovegrade 10 belowgrade operation, the 325L showed no difference in average removal rates. The 3251 . was not used from abovegrade for handling large objects because of safely concerns.

\subsection{Remote Vision System}

A remote vision system was installed hy Martin Marielta on the 325L for the purpose of recording and viewing video from different perspectives on the excavator. This information was not used to directly support the retrieval demonstration, rather it will be of value for design of future celeoperated systems. A stereo camera with pan and tilt capability was mounted on top of the operator's cab and a mono camera was installed on top of the tool hox, initially mounted in the fixed 


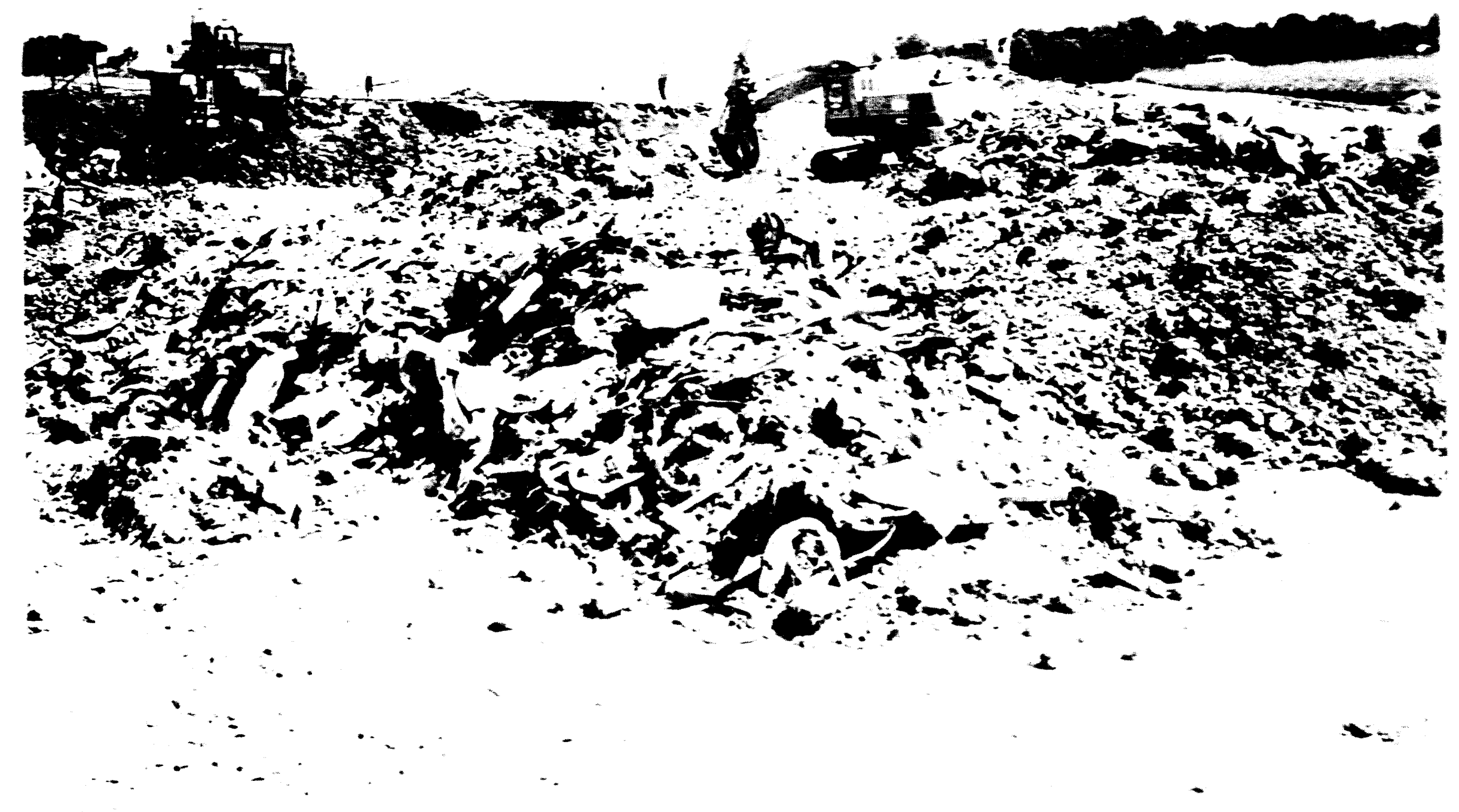




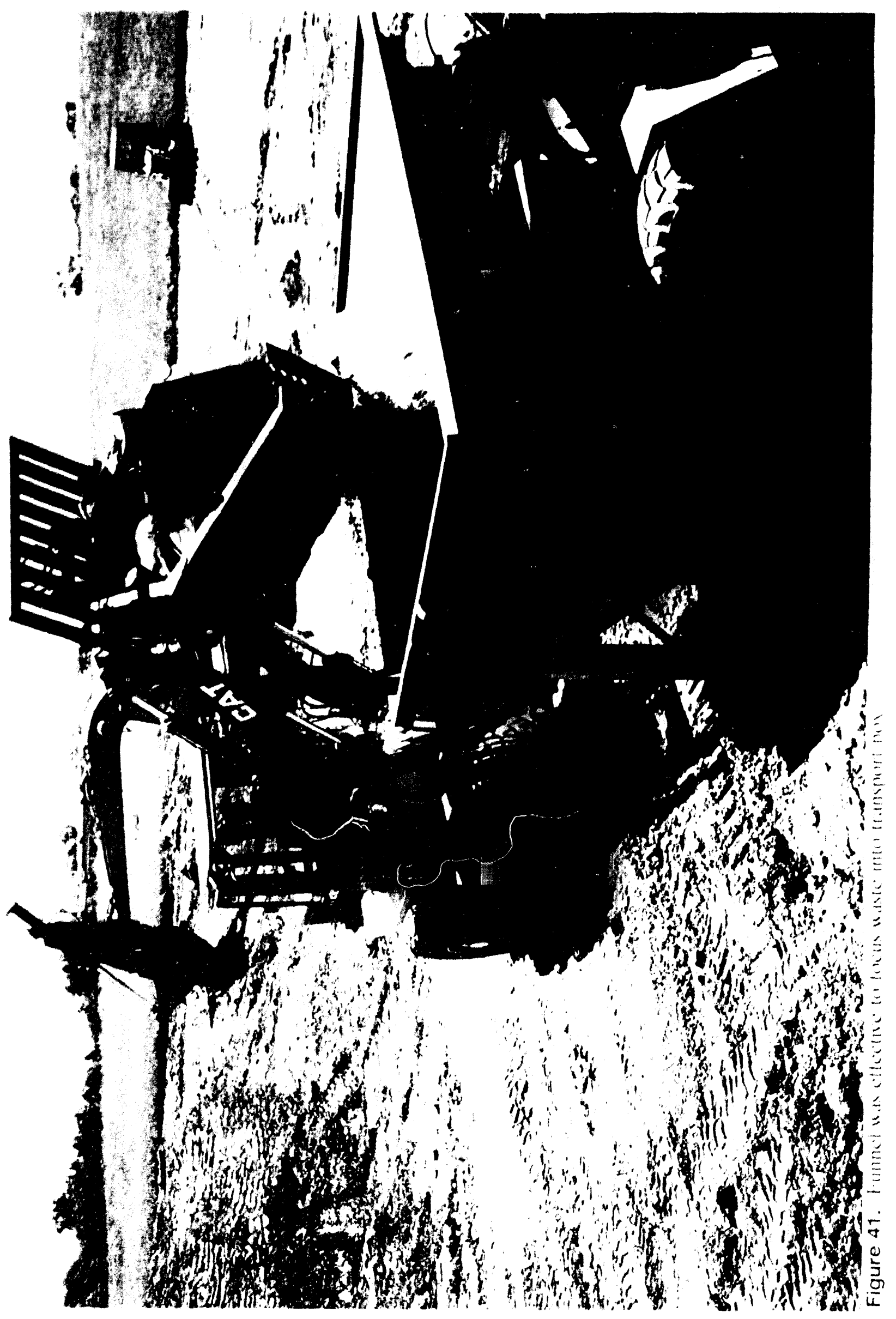


position, later with pan and tilt. These positions were selected based on requirements that the camera locations not impede the operator's vision, they provide video imagery from opposite sides of the boom, stick, and bucket, and are at different heights on the excavator. Not all candidate camera locations were evaluated during this test because time and budget limitations; however, the locations selected yiclded a good sampling of the type of information required to design a remote video system. Camera genlock signals (synchronization signal for video output) were transmitted to the excavator, and camera video was received from the excavator via umbilical cable. A vertical mast was constructed to elevate the umbilical above the excavator upper structure, providing in excess of 180 degrees of eab rotation without hitting the umbilical with either the cab or boom.

The monitors used to view the video seenes from the excavator were set up in the instrument van. A 13 -in. Sony monitor was used as the primary display device, with a 9-in. portable monitor used to complete the setup and adjustment of the cameras from the excavator. These monitors provided mono views of the excavator-mounted cameras. A switch box was connected to the camera video signals to enable the viewer to select which of the excavator cameras to view. Also connected to receive the monitor video signal was a one-half inch, S-VHS video recorder that was used to record selected portions of the video seenes currently viewed on the monitor.

Stereo video was provided in the instrument van using two different display devices. The stereo video was generated by the stereo camera mounted on the cab roof. The two camera signals were then input to a multiplexor that combined the two video signals into a single National Television Standards Committec video signal by interleaving left and right video fields. The resulting signal is a composite of the odd field from the left camera, followed by the even field from the right camera, then the next odd field from the left camera, and so on, and it is eompatible with the S-VHS recorder that was used to record video images. The stereo images were viewed from two different displays: a standard TV monitor with active glasses and an autostereo display that exploits a unique, patented lighting system to illuminate a color liquid erystal display. The two stereo displays created an illusion of depth, with the active glasses and TV monitor having the best color saturation. When compared with the mono seene from one of the two stereo cameras, the depth information displayed to the viewer was important in determining how far apart two objects were in the scene.

The equipment operator viewed a few minutes of recorded stereo imagery (not for the purpose of equipment operation) from the waste retrieval test and provided comments. He said that he would probably prefer 3-D 10 2-D (but this would require field testing) and that depth information was important in end effector placement. He also stated he would like a wide field of view to help determine the orientation of the video scene with reference to the surrounding area, and switching ability to permit him to look at other camera views. The operator also commented that depth cuing should be as close to natural as practical, which is anticipated to reduce training time.

About 4 hours of videotape from the machine mounted cameras was produced during the field test. The systems functioned well with virtually no technical difficultics (all systems had been set up and pretested before field installation). The position of the cameras provided good visual coverage of the work area and machine. However, it was obvious that an external mounted camera showing the entire machine relative to the work area would be a must in a remote operation. The goal of the this activity was to acquire information concerning the design of future remote video systems, and valuable field data was obtained to help with engineering of the next generation of remote video. 


\subsection{Data Collection}

Martin Marietta engineers collected data using three methods during the execution of the field testing to determine operational effectiveness of each piece of equipment, document the performance of the test, and provide insight into the remotizing of selected pieces of equipment. Data were collected in video form and still photography, and performance measurements were recorded on data collection sheets. All data collection was performed in accordance with the preapproved project test plan, Test Plan for the Retrieval Demonstration. ${ }^{1}$

Acquisition of videotape was accomplished through the use of the excavator-mounted cameras, as well as a hand held S.VHS camcorder and tripod. Site documentation videotape was recorded from numerous places throughout the site using the hand held S-VHS camcorder during pit construction, pit excavation, and waste hauling. Additional videotape was recorded from the excavator-mounted cameras to investigate their usefulness based on camera location, field of view, and stereo versus mono for remote operation of the excavator. The videotapes were then reviewed and a $\log$ of video shots developed. This video footage was later used to assemble a short 8 to 10 minute overview video and a 60 to 75 minute documentary of the retrieval demonstration.

Still photography was also taken to document various aspects of the test. Proof sheets were made of all of the $35-\mathrm{mm}$ film shot at the retrieval site to provide quick reference to the photographs available. Photographs representative of key aspects of the test (pit construction, excavation, and reclamation) are contained in this report. Approximately 600 still photos were taken of the various stages of the field work.

Raw data pertinent to the measurement of performance of the retrieval process were recorded on data sheets (sample data sheet is shown in Figure 42). The data collected were input to Statview a statistical analysis software package. A Macintosh Powerbook 170 was used onsite to host the Statview application for daily "quick look" analyses to assess average cycle time and average percent utilization of the end effector. Field observations were recorded directly on the data sheets as appropriate. Data were recorded for each of the equipment configurations until it was determined that the operator had reached maximum efficiency. This was a subjective observation, but the same observer was used for all data recording, and the observations were later confirmed with the equipment operator.

\subsection{Disposal of Burled Waste and Site Reclamation}

As matcrial was removed from the cold test pit, it was segregated into three separate piles, each pile corresponding to a section of the pit (random cell, soil berm, and stacked cell). After completion

of the retrieval demonstration, the simulated waste was removed from the site and sent to a local landfill. Material from each pile was loaded into a dump truck, and then each truck was weighed before it left the demonstration site to determine the weight of its load. In this manner the total weight of material removed from each cell could be determined. Weighing of the trucks was accomplished with a calibrated set of truck scales. Information from the weighing process was recorded into a field log book by a designated test engineer. The waste was then transported to a local landfill. No permits were required because the waste was considered building demolition material. Clean soil from the earth berm and pit backfill was weighed but left at the ETC to save 
Cycle \#:

TIme Start:

Time Stop:
Sheet \#:

Date:

Recorder:

Operator:

Equip. Conflguration:

\section{Sunlight \\ Intensity \\ fc \\ Cloud Cover: \\ Clear \\ Mostly Clear \\ Mostly Cloudy \\ Overcast}

Shadows:

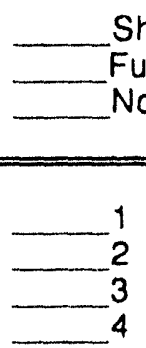

Sharp

Fuzzy

None

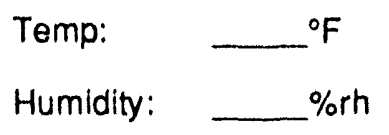

Rain:

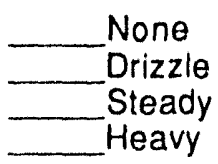

Wind:

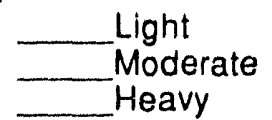

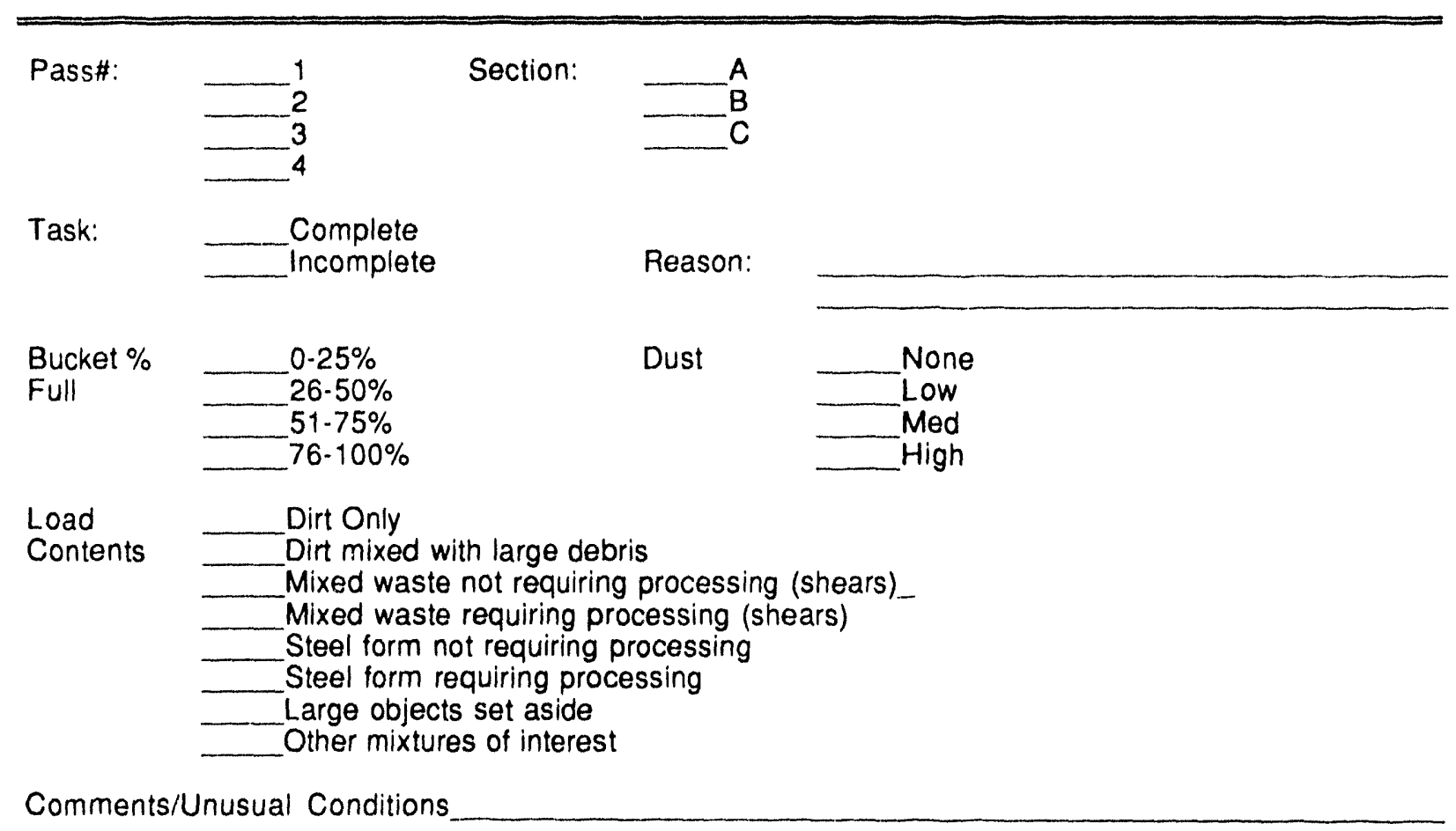

Figure 42. Sample of data collection sheet. 
landfill costs and space. The area used for the retrieval demonstration was backfilled with clean dirt, compacted, and contoured. All equipment and material used for constructing the pit and completing the demonstration was removed. The entire loading, weighing, removing, and reclaiming process required less than 3 days to complete.

\subsection{Weighing of Simulated Waste}

To determine the average weight of material in each of the cells, all soil and debris removed from the cold test pit was weighed, and the weights were recorded before disposal. As material was removed from either the stacked drums and boxes cell, soil separation berm, or the random dumped drums and boxes and large objects cell, it was placed in one of three separate piles. At the conclusion of the excavation work, the material from each pile was loaded into a transport truck; the truck was weighed and the weight recorded; and the material taken offsite for disposal at a landfill. Clean soil, such as from the separation berm, was loaded, weighed, and then dumped at the ETC to be used for backfilling the cold test pit. This avoided having to pay for transport of the soil and disposal in a landfill. A set of calibrated truck scales (owned by CAT) were used at the ETC to weight the trucks. Each truck's empty weight was initially recorded before weighing the material. The following are the total weights from each of the cells:

- Random dumped drums and boxes $839,920 \mathrm{lb} \quad 420$ tons and large objects

- Soil separation berm $579,600 \mathrm{lb} \quad 290$ tons

- Stacked drums and boxes $\quad 1,309,140 \mathrm{lb} \quad 655$ tons

The average weight of $1 \mathrm{yd}^{3}$ of material from each cell is

- Random $839.920 \mathrm{lb} / 400 \mathrm{yd}^{3}=2,100 \mathrm{lb} / \mathrm{yd}^{3}$

- Soil 579,600$) \mathrm{lb} / 150 \mathrm{yd}^{3}=3,864 \mathrm{lb} / \mathrm{yd}^{3}$

- Stacked $1,309,140 \mathrm{lb} / 550 \mathrm{yd}^{3}=2,380 \mathrm{lb} / \mathrm{yd}^{3}$

Average weight $1 \mathrm{yd}^{3}$ of material in the cold test pit

$$
839,920+579,600+1,309,140=2,728,660 \mathrm{lb} / 1,100 \mathrm{yd}^{3}=2,481 \mathrm{lb} / \mathrm{yd} 3
$$




\section{TEST RESULTS}

\subsection{Effectiveness of Selected Equipment}

A direct comparison of the different equipment configurations utilized at the retrieval demonstration was made using (a) the information oblained from approximate, straight-line measurements of pit volume removed, and (b) processed data from the data collected during the demonstration. Table 4 shows a summary of the different equipment configurations along with location of the machine, total elapsed time for the machine during the retrieval, total volume of material retrieved, and the calculated average hourly removal rate. Table 4 shows that the $325 \mathrm{~L}$ performed about as well as the EL2(K) in terms of raw production; however, the time for the $325 \mathrm{~L}$ includes removal and handling of numerous large objects and the effort required by the 235 to shear large objects. Abovegrade production for the $325 \mathrm{~L}$ was slightly better than from the belowgrade position. But again the time reflects only raw retrieval rates and does not account for handling and shearing of large objects. The table also shows the IT28 and 935 to be less effective in the removal of material with the lower average removal rates.

When a new piece of equipment was used during the test, observations were made to assess how quickly the operator gained proficiency. For example, within approximately 15 minutes, the operator was operating the $325 \mathrm{~L}$ from belowgrade at nearly maximum efficiency. His average cycle time did not improve significantly for the remainder of the demonstration while using that same machine. The $325 \mathrm{~L}$ and EL2(K) excavators were the most effective for waste retrieval (in terms of raw production), both in situ and loose material, as is evideneed in Table 4 with the average removal rate of about 50) $\mathrm{yd}^{3} /$ hour. The 935 operated well in loose material, but was too light and small for removal of in

Table 4. Equipment effectiveness shows the $325 \mathrm{~L}$ and EL200 to be equally effective in waste retrieval.

\begin{tabular}{|c|c|c|c|c|}
\hline $\begin{array}{c}\text { Machine and end } \\
\text { effector }\end{array}$ & Location & $\begin{array}{c}\text { Total clapsed } \\
\text { lime } \\
(\mathrm{h}: \mathrm{min}) \\
\end{array}$ & $\begin{array}{l}\text { Total yd } \\
\text { removed } \\
\quad\left(y d^{3}\right)\end{array}$ & $\begin{array}{c}\text { Average } \\
\text { removal rate } \\
\left(\mathrm{yd}^{3} / \mathrm{h}\right)\end{array}$ \\
\hline $\begin{array}{l}325 \text { with bucket } \\
\text { and thumb }\end{array}$ & Belowgrade & $10:(k)$ & 481 & 48.1 \\
\hline $\begin{array}{l}\text { IT28 with grip and } \\
\text { grab }\end{array}$ & Belowgrade & $1: 30$ & 55 & 36.7 \\
\hline $\begin{array}{l}935 \text { with multi- } \\
\text { purpose hucket }\end{array}$ & Belowgrade & $1:(x)$ & 35 & 35 \\
\hline $\begin{array}{l}\text { EL2(o) with } \\
\text { reversed front } \\
\text { shovel }\end{array}$ & Belowgrade & $4:(x)$ & 200 & 50 \\
\hline $\begin{array}{l}325 \text { with hucket } \\
\text { and thumb }\end{array}$ & Abovegrade & $6: 30$ & 329 & 50.6 \\
\hline
\end{tabular}


situ matcrial, and moving to a larger machine may overcome this problem. Also, the multipurpose bucket on the 935 is not the hest suited for working in heterogeneous debris. Likewise, the IT28 with grip and grab worked well in loose material but was unable to generate sufficient forces to dislodge in situ material, and substantial modifications would be required to make the IT28 with grip and grab suitable for in situ waste retrieval. Both the 9.35 and ITC28 were used for short durations because it was apparent that their production capabilities were limited compared to the 325L.

Large objects were handled exclusively by the 325L or EL200; the IT28 with grip and grab and 935 were not used in the random pit so they did not handle large objects. The EL200) was able to handle large objects: however, this was achicved by balancing the object on the bucket (i.e., there was not a positive clamping fore gripping the item to hold it stationary). The $325 \mathrm{~L}$ is more versatile because it has a thumb to provide a gripping function. None of the large objects were handled from abovegrade for safety reasons. The stability of the pit is in question any time an object is removed, possibly causing a collapse. Additionally, the extraction of large objects from the digface required predominantly horizontal motions perpendicular to the digface. Performing such operations from abovegrade would be difficult and tend to destabilize the excavator because the load is moving further away from the machine's center of gravity, increasing the overturning moment on the excavator.

The equipment operator was interviewed following operation of the last of the four pieces of equipment to garner his opinion and insights concerning which machines were most effective and why (the same person was the equipment operator for all of the machines tested). He commented that the $325 \mathrm{~L}$ was his preferred machine for three reasons. First, maximum visibility of the work area is a must, so the $325 \mathrm{~L}$ belowgrade is the preferred configuration; second, swing machines (excavators) cause less spillage than machines that require track motion to steer the machine; and third, tracked machines tend to bury spilled material when they move whereas an excavator does not need to move to pick up the spilled material. The operator also commented about his choice of abovegrade versus belowgrade. He preferred belowgrade because of better visibility. The operator can better see what he is removing and the excavator is in a more stable configuration for removing large objects. The ability to see what to remove allows the operator more time to plan the retrieval, which will increase productivity.

\subsection{Production Rates and Related Data}

Average daily production rates for the retrieval demonstration far exceeded the $80 \mathrm{yd}^{3} / \mathrm{day}^{2}$ goal with a peak daily rate of over $410 \mathrm{yd}^{3} / \mathrm{day}$ (daily rates are based on hourly rates times eight hours per day). Because of the limited size of the pit (about $1,100 \mathrm{yd}^{3}$ ), full 8 -hour production runs were not performed. However, the various equipment was operated a sufficient length of time to establish a reasonable hourly rate of production for a given waste type and operating position. Table 5 shows the average daily production rates extrapolated from the retrieval activity summary contained in Appendix B.

As a point of information and for comparative purposes, a $325 \mathrm{~L}$ excavator with a standard bucket could remove about 150 to $160 \mathrm{yd}^{3} / \mathrm{h}$ if working in an ideal material such as well graded and drained sand or gravel. Working conditions such as visibility, weather, swing distance, bumping, ete, are all assumed to be ideal to maintain the stated production. 
Table 5. Average daily rate during retrieval farr exceeded the $80 \mathrm{yd}^{3} /$ day goal.

\begin{tabular}{lccc}
\hline Date & Total yd & Elapsed lime & Average daily rate \\
\hline & & & $3(6)$ \\
Junc 7 & 145 & $3: 45$ & 240 \\
Junc 8 & 15 & $: 30$ & 360 \\
Junc 9 & 315 & $7:(x)$ & 414 \\
Junc 10 & 220 & $4: 15$ & $4(\mathrm{~K})$ \\
Junc 15 & 275 & $5: 30$ & \\
\hline
\end{tabular}

Statistical analysis of the data recorded during the retrieval demonstration shows the mean cycle times to vary according to the type of machine used for the retrieval. A cycle is considered the time required to dump a load of material into the hopper, return to the digface, grab another bucket load, and return to the hopper ready to dump. Figure 4.3 is a comparison of mean cycle times for each of the equipment items used during the field demonstration. For all statistical data discussed in this section, it is noted that the "count" or number of eycles is not a total, rather it is a representative sampling of the total number of eycles. The number of cycles recorded for data analysis purposes are about one-fourth to one-third of the total. There was adequate observed redundancy in the way cach eycle was executed to have high confidence that the cycles counted were representative of the total. Figure 4.3 shows that excavaltor-type machines have the lowest mean cycle times of the machines tested, at approximately 46 seconds. Also of interest is that the two excavators tested have virtually identical mean cycle times. The information presented in this graph and chart is corroborated with liekd observations (i.e., the excavators consistently had the lowest cycle times of the equipment tested, and these machines were superior in terms of overall production capability).

Figure 44 is a comparison of the performance of the 325L excavator from helowgrade and abovegrade positions. This graph indicates that the $325 \mathrm{~L}$ had only approximately 3 seconds difference between the mean cycle times of belowgrade and abovegrade operation (pass 1 was from the belowgrade position and pass 3 from abovegrade). The slight difference in cycle time is probably attributed to the fact that no large objects were removed from the abovegrade position, whereas all large objects were removed belowgrade and required more time to remove and handle. Also, time 10 size large objects encountered and removed during pass 1 is reflected in the mean time measurement.

Mean cycle time varied as a function of pit section. Figure 45 shows mean times for each of the pit eells. As expected the cell having the lowest mean eycle time at 38 seconds is the soil separation herm (easy to access, homogenous material), random cell mean cycle time at 50 seconds, and stacked eell mean cycle time highest of all three at 61 seconds. The difference between the mean cycle times of the random and stacked cells is pessibly altributed to the average density of the eells, with the stacked cell being approximately $10 \%$ more dense.

Percent utilization of the end effector used for waste retricval versus machine type is presented in Figure 46. Percent utilization refers to the amount that the end effector is full. The first chart shows that for more than $50 \%$ utilization, the $325 \mathrm{~L}, 93.5$ and EL200 compare equally. The ITC grip 


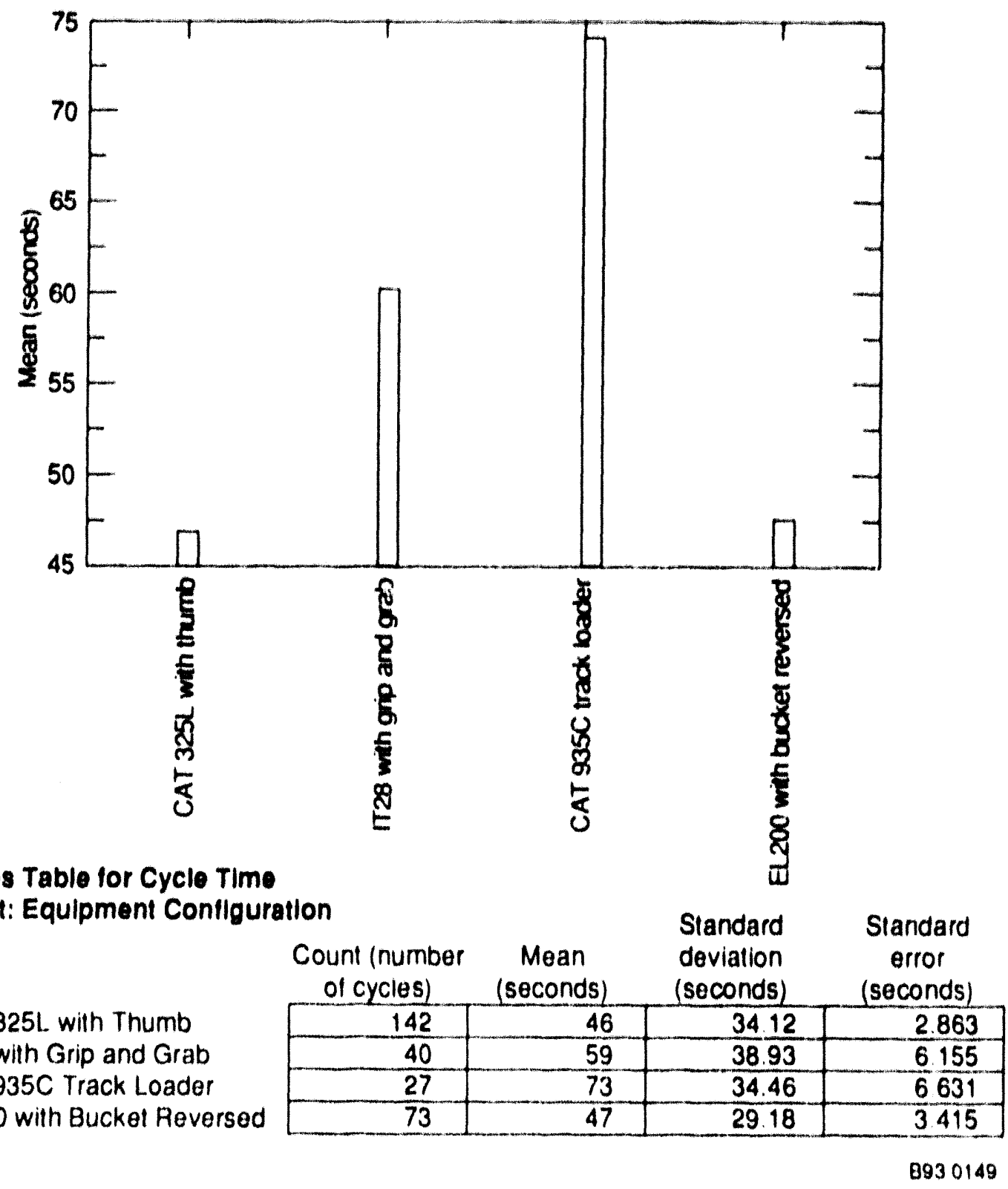

Figure 43. Comparison of cycle times for various equipment. 


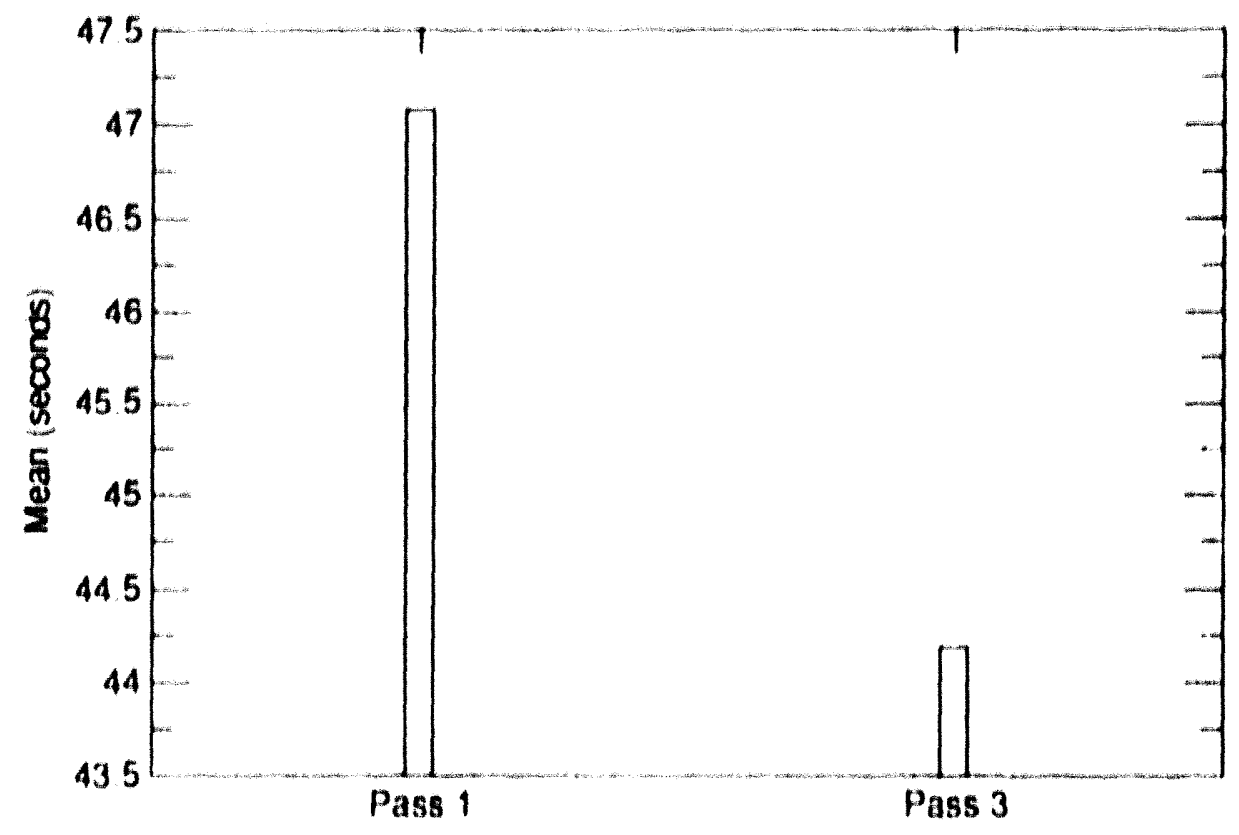

Means Table for Cycle Time

Effect: Pass *

\begin{tabular}{|c|c|c|c|c|}
\hline 888 & $\begin{array}{l}\text { Count (number } \\
\text { of cycles) }\end{array}$ & $\begin{array}{l}\text { Mean } \\
\text { (seconds) }\end{array}$ & $\begin{array}{l}\text { Slandard } \\
\text { devialion } \\
\text { (seconds) }\end{array}$ & $\begin{array}{l}\text { Standard } \\
\text { error } \\
\text { (seconds) }\end{array}$ \\
\hline Pass 1 & 99 & 47 & 35.17 & 3.535 \\
\hline Pass 3 & 43 & 44 & 31.86 & 4.858 \\
\hline
\end{tabular}

Figure 44. 325L, excavalor elficiency working from ahovegrade and helowgrade. 


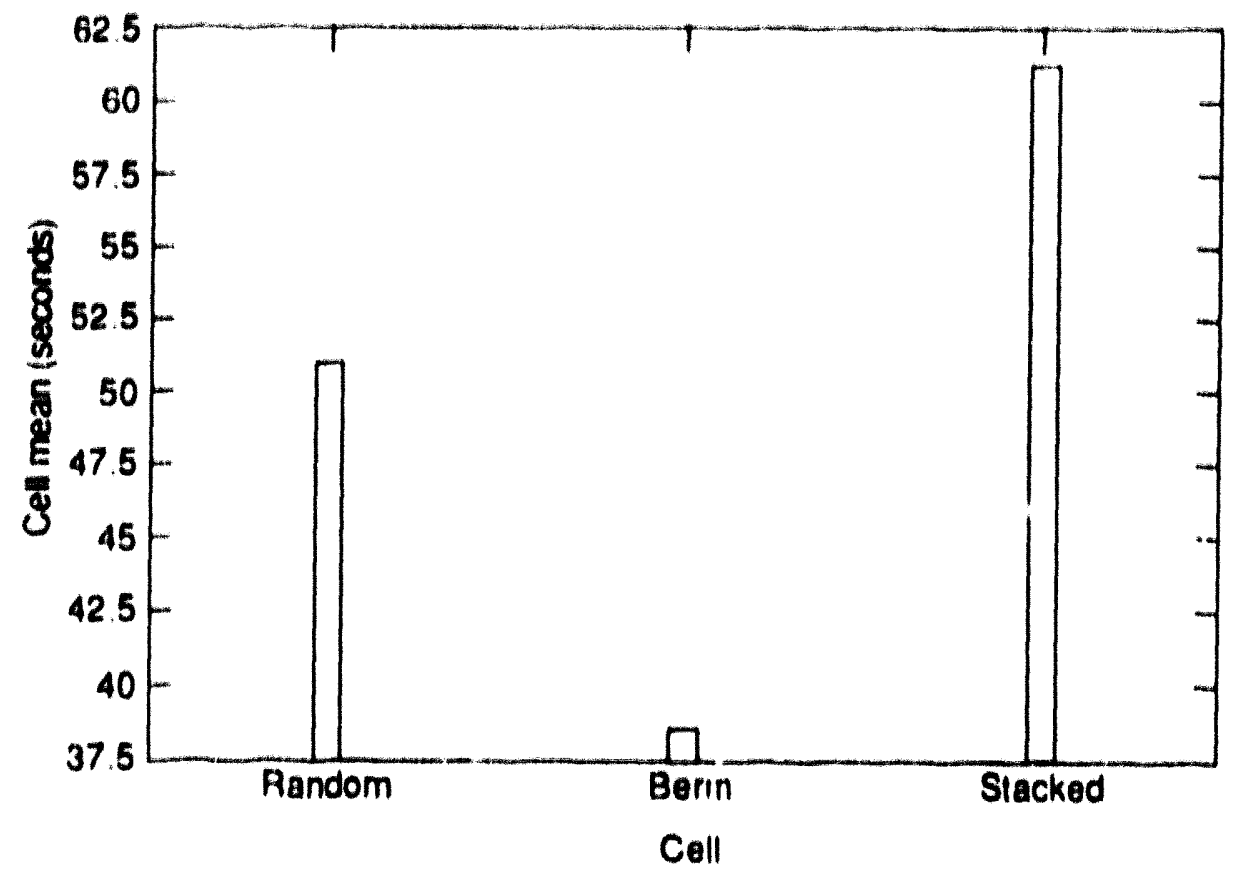

Means Table for Cycle TIme

Eflect: Sectlon

\begin{tabular}{|r|r|r|r|}
$\begin{array}{c}\text { Count (number } \\
\text { of cycles) }\end{array}$ & $\begin{array}{c}\text { Mean } \\
\text { (seconds) }\end{array}$ & $\begin{array}{c}\text { Standard } \\
\text { deviation } \\
\text { (seconds) }\end{array}$ & $\begin{array}{c}\text { Standard } \\
\text { error } \\
\text { (seconds) }\end{array}$ \\
\hline 133 & 50 & 33.91 & 2.941 \\
\hline 62 & 38 & 28.54 & 3.624 \\
\hline 87 & 01 & 36.74 & 3.939 \\
\hline
\end{tabular}

8930150

Figure 48. Mean times for ench cold test pit cell. 
Observed Frequencies for Equipment Conflguration, \% Utilization

CAT 325L wilh Thumb

IT 28 with Grip and Grab

CAT 935C Track Loader

EL200 with Bucket Roversed

Tolals

\begin{tabular}{|r|r|r|r|}
\hline $0.25 \%$ & $26.50 \%$ & $51-75 \%$ & $76.100 \%$ \\
\hline 10 & 17 & 42 & 70 \\
\hline 10 & 13 & 11 & 6 \\
\hline 3 & 1 & 4 & 19 \\
\hline 5 & 8 & 13 & 47 \\
\hline 28 & 39 & 70 & 142 \\
\hline
\end{tabular}

Tolals

139

40

27

73

279

Percents of Row Totals for Equlpment Conllguration, \% Utillzation

CAT 325L wilh Thumb IT 28 with Grip and Grab CAT 935C Track Loader EL200 wilh Buckel Reversed rolals

\begin{tabular}{|c|c|c|c|c|}
\hline $0.25 \%$ & $26.50 \%$ & $51.75 \%$ & $76.100 \%$ & Totals \\
\hline 7.194 & 12.230 & 30.216 & 50.360 & 100.000 \\
\hline 25.000 & 32500 & 27.500 & 15.000 & 100.000 \\
\hline 11111 & 3704 & 14.815 & 70.370 & 100.000 \\
\hline 6.849 & 10.959 & 17.808 & 64.384 & 100.000 \\
\hline
\end{tabular}

Percents ol Column Totals for Equipment Conflguration, \% Uillization

CAT 325L with Thumb I128 will Grip and Grab CAT 935C Track Loader EL200 with Bucket Reversed Tolals

\begin{tabular}{|r|r|r|r|}
\hline $0.25 \%$ & $26.50 \%$ & $51.75 \%$ & $76.100 \%$ \\
\hline 35.714 & 43.590 & 60.000 & 49.296 \\
\hline 35.714 & 33.333 & 15.714 & 4.225 \\
\hline 10.714 & 2.564 & 5.714 & 13.380 \\
\hline 17.857 & 20.513 & 18.571 & 33.099 \\
\hline 100000 & 100.000 & 100.000 & 100.000 \\
\hline
\end{tabular}

Totals 49.821 14.337 9.677 26.165 100.000

Figure 46. Comparison of percent utilization of different end elfectors. 
and grab has aboul iwo-thirds of its measured frequencies below $50 \%$ utilization. When examined with respect 10 the mean cycle time for each machine, the 325L and EL.2(X) excel and the 9.35 and ITC are removed from consideration. Pereent utilization versus pass number is intriguing eonsidering that more than $95 \%$ of recricuals during pass three (abovegrade) were maximum utilization of the end eflector.

Data collected from the field demonstration were entered into a Statview software program which is capable of performing a variety of statistical analyses. Only a small sampling of the numerous analyses (and information of interest) that the program can generate are presented in this report. The most critical data collected in the field were pertaining to average production rates. Information contained herein focuses on that aspect of data collection. The retrieval demonstration was performed of establish an optimum condition operating baseline. Conditions that will inlluence production in an actual hot environment such as working in a containment struclure, working around contamination control equipment, and remole operation of the equipment will reduce the average hourly production rale. Any reference to the data presented in this report should be done cautiously and qualified with the knowledge that the test was done under optimum conditions.

\subsection{Dust Suppression}

Dust generation was minimal during the retrieval demonstration. Most of the material that was: retrieved generated no dust because of the mosisture content of the soil. Moisture in the soil was present from two primary sources; lirst, there was heavy rainfall in the area before the start of construction of the cold ese pit salurated the ground. The soils at the eold lest pil are clayey and tend to readily absorb and hold moisture. Second, the pits were soaked with water before covering them with dirt io hasten delerioration of the cardheoard containers. The stacked pit was soaked with about $5 .(X)$ gal of water delivered from the ETC water wagon. Only the interred debris was welled hecause the soil to be used for backlill was in a storage pile (this soil was thinly spread over a large area it the site and was later deposited in the pit). For the randem pit, spraying with the water wagon was not necessary hecause just after the simulated waste was placed in the pit, the area was salurated hy a hellvy rainstorm, soaking the pit contents. Backfill for this cell was likewise stored in " pile and absorbed a fair amount of water. After the backlilling was completed, moisture contained in the soil was trapped. A tarp was placed over the surface of pit after linal grading was completed to keep additional surlace mosisture from solaking into the soil.

These factors resulted in moist soil that generated no or very little dust during the initial days of the lest. Toward the end of the retrieval, after having the pit open for more than 1 weet: (and no subsequent rain), small amounts of dust were observed during the dumping of waste into the lunnel. Very litlle dust was generated during the actual loading and handling of soil and debris at the digfiace.

Carclul handling and dumping of material was also important in the climination or minimization of dust generation. The operator was advised that dust generation should he minimized during the retricval demonstration al the start of retrieval operations. All activities that involve digging. handling, transporting and dumping soil and waste were accomplished with care, first, to minimiac dust and second, to reduce spillage. Beciuse the soil was damp, it cannot be determined with full confidence the extent 10 which careful and deliberale care in the handling and dumping of waste contributed to dust suppression. However, it can he stated that maximurn care was used to handle 
the waste 10 prevent the spread of airborne particulates (i.e., whether the soil was dry or moist was not of consequence, the most careful lechnique within reason was used to handle the debris). Technigues used on reduec the dispersion of dust included working matcrial into the bucket as close to the diglace as possible so spillage would not create dust. Also, the operator "sprinkled" retricved waste material slowly into the hopper, rather than all at once, which reduced the rush of air from the hopper, and consequently, the dust generated by the dumping process.

\subsection{Effectlveness of Remote Vision System}

The two camera locations on the excavalor were cvaluated with respect to providing adequate views of the work area during the course of the retrieval demonstration. The eab roof-mounted cameras gave a meaningful view of the work area, much like what a person would sec from the operator's chair. The lool hox-mounted camera view was not as good as the cab-mounted for two reasons. First, the focal length of the lens was variable, $81080 \mathrm{~mm}$, with its widest field of view at $8 \mathrm{~mm}$ as apposed $106 \mathrm{~mm}$ for the cab roof-mounted camera. The longer minimum focal length of the tool box camera resulted in a narrower lield of view, which sometimes made it difficult 10 determine the orientation of the view relative (o) the surroundings. Also, the narrower field of view obviated the need for a pan and tilt drive because the bucket has to move only a small distance before it is out of the view. Second, the location of the tool-box mounted camera was lower than that of the cab roof-mounted camera. This position contributed to its poor (relative to the cab roof camera) performance. When working abovegrade, the higher perspective offered by the eab roof camera redueed the possibility of obstructing the camera vicw by a part of the excavator or the top edge of the digface. The fool box camera was at times blocked by the right track of the excavator or the top edge of the digfiace. Also, the lool box camera was not high enough on the excivator to aid a remole observer when atlempting to look into a funnel such the one used in this demonstration.

It was decermined that each camera, wherever it is localcd, should have the capahility lo follow the end elfector. The pan and tilt units used for this demonstration were almost too slow to make this possible (the pan and till drives moved at 6 degrees/sec). The use of a fast (20 degrees/sec or heller) pan and till drive, or two or more cameras pointed at different portions of the excavator's work areih, should be explored during subsequent follow-on work to defermine their eflectiveness. Another requirement for the camera system is remote operation of the iris and zoom lens. 


\title{
7. REMOTIZING EQUIPMENT
}

\subsection{Remotizing Equipment Used for the Retrieval Demonstration}

\begin{abstract}
All of the equipment used for the manually operated retrieval demonstration can be remotized for demonstrating its use in a simulated hazardous situation using existing technology. However, with the results shown in Table 5, only two pieces of equipment should be further considered for remote control, the 325L and EL200) (or another machine with front shovel). These machines are readily converted to remote control through the use of an excavator-mounted controller, a telemetry system, and a remote operator control station. CAT has recently remotized an EL200 excavator, outfitted with a Balderson thumb end effector. The machine was successfully operated using either radio transmission or coaxial cable connected to a remote control station with video monitors. All control functions including normal operation and guidance, sensing, and emergency warning systems can be remotized.

It is required that a remotely controlled excavator provide the operator with fidelity similar to that of the in-cab controls. However, the overall productivity of the remotely controlled excavator is expected to be on the order of one-half of that of the man-in-the-cab. This reduction in productivity has been shown in previous studies and is due to the reduction the operator's perceptive information. For instance, the remote operator must use video fecdback to see what the excavator is doing. This restricts the operator to secing those objects currently in the camera's field of view. The result is the operator will function slower than if he were in the cab. Also, the operator cannot "feel" the motion of the machine from a remote stance as he would if in the operator's cab. This is the most critical piece of feedhack missing in a remote operation.
\end{abstract}

\subsection{ROM Costs ior Remotizing Equipment}

The technology to remotely control an excavator exists today in several levels of sophistication. A given system, for example, can include technology suites such as simple on/off controls, proportional controls, coordinated boom/stick/bucket movement, 3-axis joysticks, force reflection, 2D or $3 \mathrm{D}$ vision systems, vehicle positioning systems, sensing devices, vehicle health monitoring, and obstacle detection/collision avoidance.

Configuration of a specific system will depend on installation requirements addressing the amount and type of materials to be excavated, in situ construction (c.g., buried or stored waste), health and safety considerations, number of vehicles onsite, and the actual vehicle chosen for the project. As a result of these variables, determining a ROM cost for a remote system is best done by explaining the range of systems and associated costs.

For a simple teleoperated hydraulic era ator that might be used for expedient remediation, the remote control system could include three on-board cameras and a small suitcase size control station. Communications via radio link would control selected vehicle functions with no enhancements to account for remote operation. Production rates for this type of system would be extremely low compared to manual operations. Minimal safety considerations are included. Total remote system ROM cost including vehicle modifications would be on the order or $\$ 10) \mathrm{K}$. 
A highly sophisticated system used for long-term remediation of large sites would include coordinated control of vehicle movements, human engineered remote operator's station for case of continuous use, complex vision systems, vehicle systems health monitoring and prognostics, teach/learn functions, remote sensing devices, fault tolerant or fail safety software, and other systems designed for ease of operations in a contaminated environment. Production rates for this type of system could be fairly high depending on the structure of the surrounding environment. Significant safety features are included in this system. Total remote system ROM cost including vehicle modifications could easily reach $\$ 3,000 \mathrm{~K}$.

A ROM cost of about $\$ 1,000 \mathrm{~K}$ is estimated to teleoperate a $325 \mathrm{~L}$ excavator assuming a system of moderate sophistication is provided. Such a system would include a human engineered remote operator's station, force feedback, and a moderately complex vision system. The system would be designed to function in a radiation environment. Stated costs are for remote control systems only and do not include machine costs or other special provisions for working in a contaminated environment. 


\section{LESSONS LEARNED}

1. The cardboard $4 \times 4 \times 8$ - $\mathrm{ft}$ boxes used as containers in the simulated waste pit were not rigid enough to support the weight of debris without collapsing or were very difficult to fill and transport without the container breaching. To solve this problem in the field, two extra support ribs of $2 \times 4$-in. wooden studs and steel banding were added around the box to provide adequate support, and the boxes were placed empty in a stacked cell and filled in place. For the random cell, the filling was done immediately at the edge of the pit, and the boxes were dumped into the cell. This was not a major problem and was easily handled in the field. A positive aspect of this situation was that because a thinner material was used for the containers, once in place and moistened, the boxes tended to breach very easily (which was a desired characteristic of the cold test pit). In the future, a technical approach will be adhered to for specifying the boxes or other containers.

2. The use of stecl bands to maintain the integrity of the boxes while being filled complicated the retrieval process because of the free-hanging strands that were difficult to enclose in the bucket without dragging on the ground surface. This required extra effort on the operator's part to handle the bands in a way that would minimize contamination spread. This usually required the operator to lower the bucket and "fold" the banding or cable to try to grab most of the length in the bucket. A small excavator mounted shear capable of rotating and used to trim material hanging from the end effector would have been helpful.

3. During operation of the shear, a piece of one-quarter inch steel plate jammed between the shearing jaw and housing and prevented further operation of the shear. Although very powerful, the shears could not be cleared of the jam, and production was stopped. Upon further inspection, it was apparent that the steel became caught because a wear plate on the opposite side of the shears had excessive wear, which allowed a small gap to form. This gap was large enough to allow a small piece of the plate to be forced into the void. CAT had leased this machine from a local salvage company and after checking with the owner revealed that this type of problem has occurred previously, although not very frequently. Keeping the wear plate properly maintained would probably eliminate this type of problem.

4. The lack of overall dexterity of the shear hampered efficiency of the machine. The shear replaced the entire stick on the 235 excavator, removing one degree of freedom from the machine. This reduction in dexterity, combined with the need for a rotational degree of freedom on the shear, made operation cumbersome. The operator had to push the objects around to get the orientation and position right to perform the shearing operation. This resulted in slow operation of the shear. In a hot environment, it would be necessary to design a more dexterous end effector.

5. Abovegrade handling of large objects was determined to be problematic with respect to safety of the operator to the point that it was not allowed. The risn of the pit collapsing, or excavator overturning was 100 great 10 investigate abovegrade operation with large objects. 
6. Although not a major difficulty, some production loss was realized because there was only one IT28 and transport box to load waste into and to dump material. When the IT28 was in the transport and dumping cycle (usually about 1 minute), there was a short delay for the excavator operator. Most of the time the excavator operator was able to make productive use of this time by doing some preparatory work at the digface, removing large objects, removing and working with cable and banding, and using the time to carefully extract intact containers. However, occasionally there would be a minor amount of lost time due to the single transport vehicle availability. In a production scenario this problem would be overcome by introducing an additional vehicle and storage box. 


\section{RECOMMENDATIONS AND CONCLUSIONS}

\subsection{Feasibility of Using Conventional Equipment}

Based on the success of the retrieval field demonstration, it is concluded that using conventional equipment for the removal of buried waste is feasible. The primary purpose of this demonstration was to show that conventional equipment could physically remove, handle, size, and load the type of debris expected to be found in a buried waste pit or trench and maintain a production rate of at least $80 \mathrm{yd}^{3} /$ day. The desired production rate was easily met (about $400 \mathrm{yd}^{3} / \mathrm{day}$ ). Assuming that this rate was reduced to half using a remote operated system, there is still a sizable safety margin in terms of production to ensure the minimum $80 \mathrm{yd}^{3} / \mathrm{day}$ can be met. The type of huried waste encountered did not present particular problems for the $325 \mathrm{~L}$ excavator, with the exception of the trailing banding or cable, which only required additional time to handle. There are other improvements that could be made 10 ensure production is maintained, such as using a larger machine (the $325 \mathrm{~L}$ is a moderately sized excavator with a 1 -yd bucket) like a 350 or 375 , which have bucket capacities well in excess of $2 \mathrm{yd}^{3}$. Using multiple machines is an option also, depending on congestion and the size of the digface. The Balderson thumb proved to be an extremely versatile end effector, capable of handling all materials encountered during the field demonstration. The thumb was able to grasp entire $1 \mathrm{yd}^{3}$ plus sized loads of heterogeneous material, remove and handle large objects, and selectively grasp small bits of cable, wood, metal, and other tiny debris. The thumb was also able to grab intact containers, such as barrels, without breaching or damage. The shears used for the field demonstration develop 1,100 ) tons of cutting force and were readily able to cut through several inches of cast iron (the machine tool) or high strength (approximately $105,(00)$ - Ib tensile) sted plate (one-quarter inch thick). There were no large objects encountered during the demo that the shears could not cut.

Conventional equipment will need to be modified for remote operation, hardened for work in a contaminated environment, modified to accommodate decommissioning and decontamination requirements, and the modified equipment investigated for reliability and maintenance. It is has now been demonstrated that the basic technolegy to provide removal, handling, sizing, and loading of buried waste is available.

\subsection{Abovegrade Versus Belowgrade}

Belowgrade operation is slighlly favered over abovegrade operation due to reduced risk to the equipment and hecause of maximum flexibility with the machine. However, excavation could be carricd out efficiently irom either abovegrade or helowgrade assuming the work was done remotely to offer equal visibility. There could he siluations where one position would be desired over the other depending on the type of dehris or large object being removed. To allow for maximum flexibility with respect to retrieval, it may be desirable 10 include a provision in the final design configuration to excavale from either position.

Operation of the $325 \mathrm{~L}$ from the abovegrade and belowgrade positions did not reveal a signilicant difference in production capability with respect to removal of waste other than large objects. No large objects were removed from the abovegrade position because of limited visibility. The equipment operater stated he preferred the belowgrade position hecause it afforded better visibility. However, if retrieval was performed remotely, the issue of visibility probably would not be as important because cameras mounted externally from the equipment would be used to view the 
work area. Movement of the machine tracks in the belowgrade position was minimal causing only minor agitation of dust. However, at some point in the operation, it was necessary to reposition the excavator, which disturbed the ground. This situation could be mitigated by using a concrete floor with rubber track guards on the machine, applying a fixative on the surface of the floor, or using a matting material such as timber to keep the equipment out of the dirt. The abovegrade position was slightly easier, according to the operator, 10 scoop material into the bucket and did not require the use of the thumb to help stabilize the load because the load was "pulled" toward the digface, which helped 10 foree the material into the bucket. In contrast, digging from belowgrade usually required the use of the thumb to help secure the load as it "pulled" toward the machine. Another perceived disadvantage from working aw, vegegrade is that if the digface collapsed, the machine would be in danger of lalling. Also, from the abovegrade position if a large object has to be removed that the machine is positioned directly over, additional precautions may have to be taken to prevent subsidence. Very large objects are best removed from the belowgrade position. Working from abovegrade also requires the use of mats to help evenly distribute the weight of the machine to the ground. Excessive ground pressure can result in digface collapse or subsidence. The matting requires repositioning as the digface advances. Abovegrade operation requires a larger building for boom clearance, which means more expense for building cost, ventilation system, and contamination control.

\subsection{Probable Retrieval Rate}

If retrieval work commenced in a TRU environment, it should be performed remotely, in an enclosure, and contamination control would be a major concern. There would be many other constraints that would influence the probable retrieval rates. From review of the data collected during the retrieval demonstration, it is apparent that working in debris intermixed with large objects is the slowest mode of operation, about $40 \mathrm{yd}^{3} / \mathrm{hour}$. This time also includes the effort required to size, handle and , ad the large objects. Actual digging, not counting the operation of the shear, produces rates of about $50 \mathrm{yd}^{3}$ /hour, even when removing large objects. During the field test, the same operator worked the $325 \mathrm{~L}$ excavator and 2.35 with shear. In a true production scenario, it is likely that as large objects are extracted they would be set off to the side and another operator would remotely work an excavator mounted shear to perform the sizing operation.

A conservative projection for how much production would be reduced from a manual to remotely perated scenario is half. Extreme caution should be used when referencing this projection because it is only an estimate, and there is no basis other than operator experience. It is planned to conduct follow-on testing (discussed in Section 9.4) during fiscal year (FY) 1994 to examine how well a remotized 325L can retrieve huried waste. Once production statisties are available from this test, there will be a much lirmer basis for projecting probable retrieval rates with remote operaled equipment.

Halving production would mean approximalely $25 \mathrm{yd}^{3} /$ hour could be retrieved, or $200 \mathrm{yd}^{3} / \mathrm{day}$ (8-hour shift). This assumes a CAT 325L of similar configuration to the one used during the retrieval demonstration would be used in an actual buried waste retricval scenario. It is probable that the minimum $80 \mathrm{yd}^{3} /$ day retrieval geal can be met. Also, as mentioned in Section 9.1, significantly more production could be realized using larger machines or multiple excavators. 


\subsection{Follow-on Work}

Base on the results of this iritial retrieval demonstration and the likely contribution to the Environmental Restoration Program, it is recommended that a series of follow-on tests be conducted. First, a test to determine the effectiveness of using a remotized $325 \mathrm{~L}$ excavator in a cold test pit is proposed. The primary objectives of this test would be to (a) evaluate remote operations relative to production and safety, (b) evaluate functionality of state-of-the-art telerobotic contro! systems, and (c) further assess contamination control aspects. This would leap to a full-scale retrieval demonstration at a large cold test pit. This demonstration would integrate remotized equipment enclosed in a containment building with contamination control systems. Ultimately, a test of the retrieval system in a hot environment is recommended to demonstrate the feasibility of this concept for the removal of buried waste. The technology required to remotize and operate equipment and safely contain the spread of contamination currently exists; however, an aggressive testing and demonstration program must be undertaken to ensure the necessary systems are integrated and refined to a level that will truly support the safe and cffective retrieval of buried waste.

\subsection{Contamination Control Observations}

It appears from the observations made during the manual field demonstration that to some extent the spread of dust can be controlled by carefully operating equipment at the digface to minimize disturbance of the waste during removal. During the field test, the equipment was operated in a careful manner to slowly and carefully grasp, scoop, and otherwise gather the soil and debris into the end effector. Little visual dust was observed during this process. However, as mentioned in this final report, the soil was moist during much of the test, and an accurate means of measuring dust disnersal was not a stated data quality objective. Observations were made exclusively on a visual hasis.

It is prudent to conclude that carefully operating a retrieval mechanism can minimize dust generation, but this by itself is not a substitute for a full dust suppression and contamination control system. Any retrieval activity in an actual hot environment would require a complete and separate dust suppression and contamination control system that would probably entail misting and spraying systems, application of fixatives on the digface, directed airflow, special filters, and possible use of electrostatic devices. Careful excavation only reduces the amount of dust generated, it will not climinate it.

\subsection{Remotization Feasibility}

The success of the manually operated retrieval demonstration and the large base of knowledge that already exists relative 10 remote equipment operation support the feasihility of remotization of equipment for TRU huried waste removal. The notion that equipment can be remotized and teleoperated for the removal of buried waste is already well documented (CAT and other companies have conducted extensive testing and developed remole operated equipment). Questions that remain 10) be answered about teleoperation include sustained production rates, reliability, and enhancing operator useability. Proposed follow on-work to the retrieval demonstration scheduled for FY.94 would address these issues. 
The primary purpose of a teleoperated retrieval demonstration would be to establish a baseline for the rate of production that could be achieved using a given equipment configuration. Likewise, the reliability and functionality of the remote control system would also be examined during a test retrieval scenario. A comparison of the 2-D and 3-D camera systems would be planned to help determine which visual system is most beneficial to the operator. 


\section{REFERENCES}

1. D. J. Valentich, Test Plan for the Retrieval Demonstration, EG\&G Idaho, Inc., EGG.WTD10744, May 1993.

2. EG\&G Idaho, Inc., "Statement of Work for the Retrieval Demonstration," October 1992.

3. R. E. Heard and J. L. Morrison, Buried Waste Integrated Demonstration Test Objectives, EG\&G Idaho, Inc., EGG-WTD-10878, May 1993.

4. Caterpillar Performance Handbook, 23rd edition, October 1992. 
Appendix A

Cold Test Pit Requirements

Verification Matrix

A. 1 


\section{Appendix A}

\section{Cold Test Pit Requirements Verification Matrix}

\section{RETRIEVAL DEMONSTRATION}

Table $A \cdot 1$ is a checklist to ensure that requirements as originally noted in subcontract No. C93170232 Statement of Work are met. Initially, this table was used for planning purposes. As the program progressed and actual work was performed, the table confirmed that tasks were completed. The figures referenced in the table are found in Test Plan for the Retrieval Demonstration, EGGWTD-10744, May 1993.

Table A-1. Verification matrix.

\begin{tabular}{|c|c|c|c|c|c|c|c|}
\hline Specification & EII & $\mathrm{CO}$ & VA & AL. & $\mathrm{I}: \mathrm{X}$ & $N / U$ & Comments \\
\hline $\begin{array}{l}\text { Work will be performed it a site to he provided } \\
\text { by the subeontractor. }\end{array}$ & & $\mathrm{x}$ & & & & & \\
\hline $\begin{array}{l}\text { All utilities and services used in } \\
\text { conjunction with the demonstration such } \\
\text { as watcr, power, phone, and sanitary } \\
\text { facilities shall be furnished by the } \\
\text { subcontractor. }\end{array}$ & & $x$ & & & & & \\
\hline $\begin{array}{l}\text { All materials, such as the simulated } \\
\text { debris, containers, and plastic liners used } \\
\text { in cold test pit construction or loading } \\
\text { and transfer of retrieved simulated waste } \\
\text { are to be subcontractor provided. }\end{array}$ & & $\mathrm{X}$ & & & & & \\
\hline $\begin{array}{l}\text { All equipment, vehicles, end effectors, } \\
\text { and other mechanical items necessary to } \\
\text { demonstrate the effectiveness of } \\
\text { conventional retricval shall be supplied } \\
\text { by the subcontractor. }\end{array}$ & & $\mathrm{X}$ & & & & & \\
\hline $\begin{array}{l}\text { Any other labor, supervision, facilitics, } \\
\text { materials equipment, transportation, } \\
\text { fuel, tools, and technology required to } \\
\text { provide a full and complete } \\
\text { demonstration as described herein shall } \\
\text { be furnished by the subcontractor. }\end{array}$ & & $\mathrm{X}$ & & & & & \\
\hline $\begin{array}{l}\text { Construction of a cold test pit at a } \\
\text { subcontractor provided site. }\end{array}$ & & $\mathrm{X}$ & & & & & \\
\hline Site must be located on private land. & & $x$ & & & & & \\
\hline
\end{tabular}


Table A-1. continued.

\begin{tabular}{|c|c|c|c|c|c|c|c|}
\hline Specification & lill & (c) & VA & $\mathrm{Al}$ & I:x & $N / U$ & Comments \\
\hline $\begin{array}{l}\text { Pit will be comprised of two large cells } \\
\text { and a separation berm. }\end{array}$ & & $x$ & & & & & \\
\hline $\begin{array}{l}\text { First cell will contain random dumped } \\
\text { boxes and drums, and large objects. }\end{array}$ & & $X$ & & & & & \\
\hline $\begin{array}{l}\text { Second cell will contain stacked boxes } \\
\text { and stacked drums. }\end{array}$ & & $x$ & & & & & \\
\hline $\begin{array}{l}\text { Overall pit length is } 70 \mathrm{ft} \text {, width } 32 \mathrm{ft} \text {, } \\
\text { and depth } 13 \mathrm{ft} \text {. }\end{array}$ & & $x$ & & & & & \\
\hline $\begin{array}{l}\text { Figure } 2 \text { shows the layout of the pit and } \\
\text { access areas required for excavation. }\end{array}$ & & $x$ & & & & & \\
\hline $\begin{array}{l}\text { Subcontractor shall supply a site that is } \\
\text { not only capable of locating the pit but } \\
\text { allows adequatc space for laydown, } \\
\text { staging and access of equipment, and } \\
\text { other activities that will be conducted in } \\
\text { support of the demonstration. }\end{array}$ & & $x$ & & & & & \\
\hline $\begin{array}{l}\text { Minor adjustment to the layout, shown } \\
\text { in Figure } 2 \text { are allowed to aceommodate } \\
\text { site specific conditions at the } \\
\text { subcontractors work area. }\end{array}$ & & $x$ & & & & & \\
\hline $\begin{array}{l}\text { The pit must be excavated so that it is } \\
\text { below the surrounding ground level and } \\
\text { contained by carth walls. }\end{array}$ & & $X$ & & & & & \\
\hline $\begin{array}{l}\text { Building the pit so the bottom is at } \\
\text { existing grade and then covering the } \\
\text { debris with soil is not acceptable. }\end{array}$ & & $x$ & & & & & $\begin{array}{l}\text { Pit was not } \\
\text { constructed in this } \\
\text { manner. }\end{array}$ \\
\hline $\begin{array}{l}\text { As is shown on Figure } 3 \text {, the random } \\
\text { dumped boxes and drums cell is } 25 \mathrm{ft} \\
\text { long, } 32 \mathrm{ft} \text { wide, } 1.3 \mathrm{ft} \text { deep and contains } \\
385 \mathrm{yd}^{3} \text { of volume. }\end{array}$ & & $X$ & & & & & \\
\hline $\begin{array}{l}\text { All volume calculations stated herein are } \\
\text { neat line, and no allowance is made for } \\
\text { subsidence or compaction of soil and } \\
\text { materials. }\end{array}$ & & $x$ & & & & & \\
\hline $\begin{array}{l}\text { The random dumped boxes and drums } \\
\text { cell shall contain } 25(4 \times 4 \times 8 \mathrm{ft}) \\
\text { cardboard boxes and } 3.30 \text { drums (a } 55 \text {-gal } \\
\text { container, approximate size, } 2 \text { ft } \\
\text { diameter } \times 3 \text { ft long). }\end{array}$ & & & $X$ & & & & $\begin{array}{l}\text { Cell contained } 327 \\
\text { drums. }\end{array}$ \\
\hline
\end{tabular}


Table A.1. conlinucd.

\begin{tabular}{|c|c|c|c|c|c|c|c|}
\hline Specificallion & $1: 11$ & $(\mathrm{CO}$ & VA & $\Lambda \mathrm{L}$ & $1: x$ & $\mathrm{~N} / \mathrm{ll}$ & Comments \\
\hline $9(1 \%$ of the drums shall be cardbourd. & & & $X$ & & & & $\begin{array}{l}\text { Short by } 5 \text { metal } \\
\text { drums. }\end{array}$ \\
\hline $10 \%$ of the drums shall be metal. & & & $\mathrm{X}$ & & & & $\begin{array}{l}5 \text { extra cardboard } \\
\text { drums. }\end{array}$ \\
\hline $\begin{array}{l}\text { Each box and drum shall be filled to a } \\
\text { minımum volume of } 75 \% \text {. }\end{array}$ & & $\mathrm{X}$ & & & & & \\
\hline $\begin{array}{l}\text { Prior to placement of debris inside a hox } \\
\text { or drum a clear } 4 \text { mil polyethylene liner } \\
\text { will be installed (note: do not use any } \\
\text { matcrial other than polyethylene). }\end{array}$ & & $\mathrm{X}$ & & & & & \\
\hline $\begin{array}{l}\text { Materials may, to a reasonable exlent, } \\
\text { be placed loosely in containers, hut hand } \\
\text { packing shall be employed to reduce } \\
\text { wasted space. }\end{array}$ & & $\mathrm{X}$ & & & & & \\
\hline $\begin{array}{l}19 \text { of the boxes shall he filled with serap } \\
\text { metal and the remaining } 6 \text { shall be lilled } \\
\text { with a combination of concrete and } \\
\text { asphalt chunks and scrap wood. }\end{array}$ & & & $\mathrm{x}$ & & & & $\begin{array}{l}13 \text { of the boxes } \\
\text { were filled with } \\
\text { scrap metal, } 10 \text { with } \\
\text { concrete, asphalt } \\
\text { wood, and } 2 \text { with } \\
\text { paper, cloth, } \\
\text { concrete, asphalt, } \\
\text { steel scraps, and } \\
\text { material from } \\
\text { gencral clean up of } \\
\text { the site. }\end{array}$ \\
\hline $\begin{array}{l}\text { The metal may be comprised of scrap } \\
\text { objects, wire, cable, pipe, tubing. tools, } \\
\text { filtings, structural and plate members. }\end{array}$ & & $\mathrm{X}$ & & & & & \\
\hline $\begin{array}{l}\text { Generally, metal items shall not exeecd } \\
16 \text { in. in diameter, except for as } \\
\text { specilied herein. }\end{array}$ & & $\mathrm{X}$ & & & & & \\
\hline
\end{tabular}


Table A-1. continued.

\begin{tabular}{|c|c|c|c|c|c|c|c|}
\hline Specificulion & BH & $\mathrm{CO}$ & VA & Al. & $\mathrm{EX}$ & $\mathrm{N} / \mathrm{U}$ & Comments \\
\hline $\begin{array}{l}\text { Scrap stainless and carbon stecl plate } \\
\text { shall be included in at least } 5 \text { of the } \\
\text { boxes. }\end{array}$ & & & $\mathrm{X}$ & & & & $\begin{array}{l}\text { Per the kick-off } \\
\text { meeting, high } \\
\text { strength steel will be } \\
\text { used in place of } \\
\text { stainless, provided } \\
\text { the substitute } \\
\text { material has a } \\
\text { tensile strength } \\
\text { equal to at least that } \\
\text { of the stainless } \\
\text { material. Also the } \\
\text { substitute material } \\
\text { shall be clearly } \\
\text { marked to identify it } \\
\text { as the high tensile } \\
\text { strength stecl. }\end{array}$ \\
\hline $\begin{array}{l}\text { The plate shall be irregularly shaped and } \\
\text { be a minimum of } 5 \mathrm{ft}^{2} \text { in size. Irregular } \\
\text { shapes may include triangles and } \\
\text { polygons. }\end{array}$ & & & $\mathrm{X}$ & & & & $\begin{array}{l}\text { All } 10 \text { pieces are } \\
\text { rectangular. }\end{array}$ \\
\hline $\begin{array}{l}\text { The concrete and asphalt chunks shall } \\
\text { comprise at least } 60 \% \text { of the volume of } \\
\text { a box, and the remaining } 40 \% \text { volume } \\
\text { shall be wood. }\end{array}$ & & $\mathrm{X}$ & & & & & \\
\hline $\begin{array}{l}\text { Generally, the concrete, asphalt and } \\
\text { wood pieces shall not exceed } 12 \text { in. in } \\
\text { diameter. }\end{array}$ & & $\mathrm{X}$ & & & & & \\
\hline $\begin{array}{l}\text { It is required that these materials be } \\
\text { well mixed when placed inside of the } \\
\text { boxes. }\end{array}$ & & $x$ & & & & & \\
\hline $\begin{array}{l}\text { 50 drums will be filled with a simulated } \\
\text { sludge material. }\end{array}$ & & & $\mathrm{X}$ & & & & 45 filled with sludge. \\
\hline 50) drums will be filled with concrete. & & $x$ & & & & & \\
\hline $\begin{array}{l}165 \text { drums will be filled with paper, } \\
\text { wood, and cloth. }\end{array}$ & & $\mathrm{X}$ & & & & & \\
\hline 35 drums will be filled with metal. & & & $\mathrm{x}$ & & & & 38 filled with metal. \\
\hline $\begin{array}{l}30 \text { drums will be filled with a random } \\
\text { mixture of materials. }\end{array}$ & & & $\mathrm{X}$ & & & & $\begin{array}{l}29 \text { filled with } \\
\text { random materials. }\end{array}$ \\
\hline
\end{tabular}




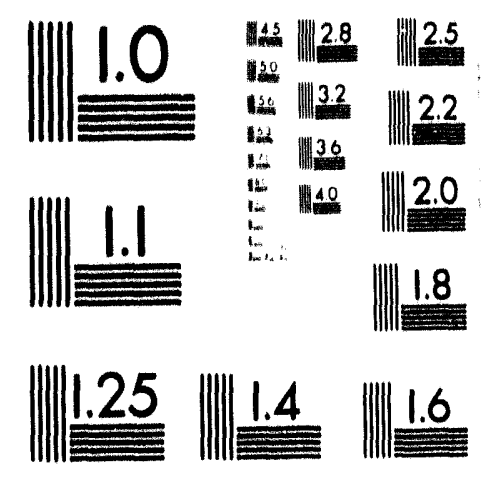



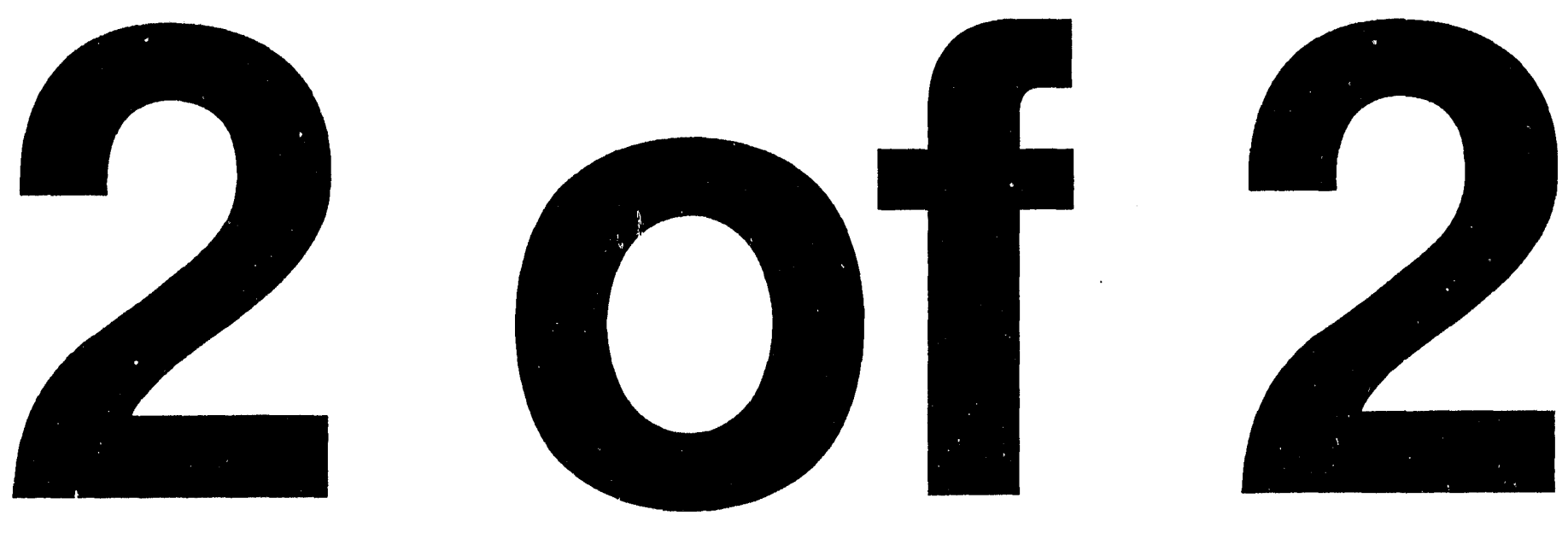
Table A-1. continued.

\begin{tabular}{|c|c|c|c|c|c|c|c|}
\hline Specification & 1:11 & $\mathrm{CO}$ & VA & $\mathrm{Al}$. & EXX & $\mathrm{N} / \mathrm{U}$ & Comments \\
\hline $\begin{array}{l}\text { For the drums filled with simulated } \\
\text { sludge, the material shall be made from } \\
\text { equal amounts of MICRO-CEL E, a } \\
\text { calcium silicate product manufactured by } \\
\text { Celine Corporation ( } 805-735-7791 \text { ), Oil } \\
\text { Dry (cat litter), and food grade } \\
\text { vegetable oil. }\end{array}$ & & $X$ & & & & & \\
\hline $\begin{array}{l}\text { Mixing the given ratio of ingredients } \\
\text { should produce a sludge like material } \\
\text { about the consistency of a thick paste or } \\
\text { grease. }\end{array}$ & & $X$ & & & & & \\
\hline $\begin{array}{l}\text { The simulated sludge shall, be well } \\
\text { mixed with no pockets of dry material } \\
\text { present. }\end{array}$ & & $X$ & & & & & \\
\hline $\begin{array}{l}\text { Minimum } 2,00()-\mathrm{lb} \text { strength concrete } \\
\text { shall be poured into } 50 \text { of the drums, } \\
\text { and the drum left open to the } \\
\text { atmosphere for a minimum of } 1 \text { week to } \\
\text { promote curing. }\end{array}$ & & $X$ & & & & & \\
\hline $\begin{array}{l}165 \text { of the drums will be filled with } \\
\text { paper, wood, and cloth material. }\end{array}$ & & $X$ & & & & & \\
\hline $\begin{array}{l}\text { The paper may be bond, newsprint, } \\
\text { computer, etc. of the type that could be } \\
\text { acquired in bulk from a recycling center. }\end{array}$ & & & $X$ & & & & $\begin{array}{l}\text { Cardboard used for } \\
90 \% \text { of the drums. }\end{array}$ \\
\hline $\begin{array}{l}\text { The wood shall be scrap material not to } \\
\text { exceed } 12 \text { in. in diameter. }\end{array}$ & & $X$ & & & & & \\
\hline $\begin{array}{l}\text { The cloth may be a bulk type of clothing } \\
\text { or canvas based material. }\end{array}$ & & $X$ & & & & & \\
\hline $\begin{array}{l}\text { Each barrel shall be filled with } \\
\text { approximate equal amounts of the three } \\
\text { materials. }\end{array}$ & & $X$ & & & & & \\
\hline $\begin{array}{l}\text { Depending on the availability of } \\
\text { material, some variation to this mixture } \\
\text { may be allowed, but shall be noted. }\end{array}$ & & $X$ & & & & & \\
\hline $\begin{array}{l}\text { Of the } 35 \text { drums filled with metal, it } \\
\text { shall be the same type of material as } \\
\text { described above for the boxes. }\end{array}$ & & $X$ & & & & & \\
\hline
\end{tabular}


Table A-1. continued.

\begin{tabular}{|c|c|c|c|c|c|c|c|}
\hline Specification & EH & $\mathrm{CO}$ & VA & $\mathbf{A L}$ & EX & $\mathrm{N} / \mathrm{U}$ & Comments \\
\hline $\begin{array}{l}\text { The remaining } 30 \text { drums may be } \\
\text { randomly filled with a mixture of the } \\
\text { above solid materials (no simulated } \\
\text { sludge or concrete). }\end{array}$ & & $X$ & & & & & \\
\hline $\begin{array}{l}\text { No hazardous or radioactive materials } \\
\text { may be interned in any portion of the } \\
\text { cold test pit. }\end{array}$ & & $X$ & & & & & \\
\hline $\begin{array}{l}\text { Food refuse, commercial or household } \\
\text { trash and garbage and any other articles } \\
\text { not mentioned above are not allowed as } \\
\text { part of the simulated waste. }\end{array}$ & & $X$ & & & & & \\
\hline $\begin{array}{l}\text { Boxes and drums my be banded after } \\
\text { materials are placed inside to help } \\
\text { stabilize the container during placement. }\end{array}$ & & $X$ & & & & & \\
\hline $\begin{array}{l}\text { Once the containers are filled, the } \\
\text { polyethylene liner shall be secured } \\
\text { around the material and the cardboard } \\
\text { (or metal) lid placed over the container. }\end{array}$ & & & $X$ & & & & $\begin{array}{l}\text { Some of the boxes } \\
\text { were filled in place } \\
\text { in the pit; for safety } \\
\text { reasons it was } \\
\text { difficult to reach the } \\
\text { box and secure the } \\
\text { liner, so the liners } \\
\text { were left open. } \\
\text { This did not have an } \\
\text { impact on the } \\
\text { demonstration. }\end{array}$ \\
\hline $\begin{array}{l}\text { The random dumped boxes and drums } \\
\text { cell shall also contain large objects. }\end{array}$ & & $X$ & & & & & \\
\hline
\end{tabular}


Table A-1. continued.

\begin{tabular}{|c|c|c|c|c|c|c|c|}
\hline Specification & EH & $\mathrm{CO}$ & VA & $\mathrm{AL}$ & EX & $\mathrm{N} / \mathrm{U}$ & Comment; \\
\hline $\begin{array}{l}\text { The large objects hall be comprised of } \\
\text { - } \quad \text { Pick up truck bed } \\
\text { Five } 15 \text {-ft lengths of carbon steel } \\
\text { pipe of varying diameter and } \\
\text { schedule (minimum diameter } 4 \text { in. } \\
\text { and minimum schedule } 40 \text { ) } \\
\text { Five } 15-\mathrm{ft} \text { lengths of carbon steel } \\
\text { structural steel shapes of varying } \\
\text { weight (minimum } 16 \mathrm{lb} / \text { lineal foot } \\
\text { weight) } \\
\text { A scrap 6-ft lathe (or similar large } \\
\text { milling/machining tool } \\
\text { A minimum } 6 \mathrm{ft} \text { diameter and } 10 \mathrm{ft} \\
\text { long carbon steel tank } \\
\text { A } 6-\mathrm{ft} \text { carbon steel cube } \\
\text { A minimum of } 500 \mathrm{ft} \text { of } 3 / 4 \text { in. (or } \\
\text { larger) steel cable (in minimum } 50 \text { )- } \\
\mathrm{ft} \text { lengths) shall be randomly } \\
\text { intertwined throughout the entire } \\
\text { cell. }\end{array}$ & & $\begin{array}{l}X \\
X \\
X \\
X\end{array}$ & $X$ & & & & $\begin{array}{l}\text { A } 52 \text { in. diameter } x \\
18 \mathrm{ft} \text { long carbon } \\
\text { steel tank was used. }\end{array}$ \\
\hline $\begin{array}{l}\text { Boxes, drums and large objects shall be } \\
\text { randomly dispersed throughout the cell. }\end{array}$ & & $X$ & & & & & \\
\hline $\begin{array}{l}\text { Containers and large objects shall be } \\
\text { placed at all levels through the waste } \\
\text { seam (i.e., objects should not all be } \\
\text { placed at ground level and covered). }\end{array}$ & & $X$ & & & & & \\
\hline $\begin{array}{l}\text { Some containers may be randomly } \\
\text { "clustered" especially near the cell } \\
\text { perimeter. }\end{array}$ & & $X$ & & & & & \\
\hline $\begin{array}{l}\text { No particelar care needs to be observed } \\
\text { when the containers are placed in the } \\
\text { cell. }\end{array}$ & & $X$ & & & & & \\
\hline $\begin{array}{l}\text { If some are dropped and breached } \\
\text { during the placement process, this is } \\
\text { preferable as this condition will simulate } \\
\text { that expected in an actual buried waste } \\
\text { pit or trench. }\end{array}$ & & $X$ & & & & & \\
\hline $\begin{array}{l}\text { As containers and objects are placed, } \\
\text { clean fill dirt shall be placed around } \\
\text { them. }\end{array}$ & & $X$ & & & & & \\
\hline
\end{tabular}


Table A-1. continued.

\begin{tabular}{|c|c|c|c|c|c|c|c|}
\hline Specification & $\mathrm{EH}$ & $\mathrm{CO}$ & VA & AL & EX & $\mathrm{N} / \mathrm{U}$ & Comments \\
\hline $\begin{array}{l}\text { Once placed, the cardboard containers } \\
\text { shall have any banding cut. }\end{array}$ & & & $X$ & & & & $\begin{array}{l}\text { Due to safety } \\
\text { concerns not all } \\
\text { banding was cut } \\
\text { because of difficulty } \\
\text { in obtaining access. }\end{array}$ \\
\hline $\begin{array}{l}\text { Prior to burial, containers shall be } \\
\text { soaked and saturated with water to } \\
\text { hasten deterioration of the cardboard } \\
\text { and promote breaching. }\end{array}$ & & $X$ & & & & & \\
\hline $\begin{array}{l}\text { As soil is filled in around large objects } \\
\text { and containers it shall be reasonable } \\
\text { well packed. }\end{array}$ & & $X$ & & & & & \\
\hline $\begin{array}{l}\text { A target compaction value of about } \\
85 \% \text { of maximum density is suggested. }\end{array}$ & & $X$ & & & & & \\
\hline $\begin{array}{l}\text { A maximum of } 4 \text { psi may be exerted by } \\
\text { personnel and equipment working on } \\
\text { top of the cell. }\end{array}$ & & $X$ & & & & & \\
\hline $\begin{array}{l}\text { A } 10 \mathrm{ft} \text { wide earth berm shall be placed } \\
\text { between the random dumped boxes and } \\
\text { drums cell and the stacked boxes and } \\
\text { drum cell. }\end{array}$ & & $X$ & & & & & \\
\hline $\begin{array}{l}\text { This berm shall be constructed of clean } \\
\text { soil and shall be compacted to at least } \\
90 \% \text { of maximum density. }\end{array}$ & & $X$ & & & & & \\
\hline $\begin{array}{l}\text { A minimum } 1-\mathrm{ft} \text { layer of soil shall be } \\
\text { placed over the } 12 \mathrm{ft} \text { thick waste seam. }\end{array}$ & & $X$ & & & & & \\
\hline $\begin{array}{l}\text { No containers or objects may protrude } \\
\text { beyond the waste seam. }\end{array}$ & & $X$ & & & & & \\
\hline $\begin{array}{l}\text { The top layer of soil shall be level and } \\
\text { compacted to at least } 90 \% \text { of maximum } \\
\text { density. }\end{array}$ & & $X$ & & & & & \\
\hline $\begin{array}{l}\text { The stacked boxes and drums cell is } \\
\text { - } \quad 35 \mathrm{ft} \text { long } \\
\text { - } 32 \mathrm{ft} \text { wide } \\
\text { - } 13 \mathrm{ft} \text { deep } \\
\text { - } \quad \text { Contains approximately } 540 \mathrm{yd}^{3} \text { of } \\
\text { volume. }\end{array}$ & & $\begin{array}{l}X \\
X \\
X \\
X\end{array}$ & & & & & \\
\hline
\end{tabular}


Table A-1. continued.

\begin{tabular}{|c|c|c|c|c|c|c|c|}
\hline Specilication & I:II & $\mathrm{co}$ & VA & $\mathrm{Al}$ & $\mathrm{l}: \mathrm{X}$ & $\mathrm{N} / \mathrm{U}$ & Comments \\
\hline $\begin{array}{l}\text { For the stacked boxes and drums cell, a } \\
\text { total of } 28 \text { boxes shall be arranged on } \\
\text { the half of the cell closest to the berm } \\
\text { as shown in Figure } 4 \text {. }\end{array}$ & & $\mathrm{X}$ & & & & & \\
\hline The boxes shall be stacked two high. & & $X$ & & & & & \\
\hline $\begin{array}{l}\text { It is required that the boxes be stacked } \\
\text { on wooden pallets. }\end{array}$ & & $\mathrm{X}$ & & & & & \\
\hline $\begin{array}{l}\text { Drums will be stacked on the other half } \\
\text { of the cell. }\end{array}$ & & $\mathrm{X}$ & & & & & \\
\hline $\begin{array}{l}\text { Approximately } 220 \text { drums will be } \\
\text { included in this side of the pit and } \\
\text { arranged as shown in Figure } 4 \text {. }\end{array}$ & & $\mathrm{X}$ & & & & & $\begin{array}{l}223 \text { drums were } \\
\text { interred in the cell. }\end{array}$ \\
\hline $\begin{array}{l}\text { The composition of the material used to } \\
\text { fill the boxes and drums in this cell shall } \\
\text { be the same as what was previously } \\
\text { described for the random dumped boxes } \\
\text { and drums cell. }\end{array}$ & & $\mathrm{X}$ & & & & & \\
\hline $\begin{array}{l}\text { Containers shall be the same size and } \\
\text { type of material ( } 90 \% \text { cardboard and } \\
10 \% \text { metal drums), lined with } \\
\text { polyethylene, and filled with the same } \\
\text { type of debris as described above for the } \\
\text { random dumped boxes and drums cell. }\end{array}$ & & & $X$ & & & & $\begin{array}{l}206 \text { cardboard and } \\
17 \text { stecl drums. }\end{array}$ \\
\hline $\begin{array}{l}\text { The metal drums shall be randomly } \\
\text { dispersed through the stacked drums } \\
\text { at d of the cell. }\end{array}$ & & $\mathrm{X}$ & & & & & \\
\hline $\begin{array}{l}\text { Containers shall be a minimum of } 75 \% \\
\text { full before closure. }\end{array}$ & & $\mathrm{X}$ & & & & & \\
\hline $\begin{array}{l}21 \text { of the boxes shall be filled with } \\
\text { metal. }\end{array}$ & & $X$ & & & & & \\
\hline $\begin{array}{l}7 \text { of the boxes shall be filled with } \\
\text { concrete, asphalt, and wood. }\end{array}$ & & $\mathrm{X}$ & & & & & \\
\hline $\begin{array}{l}3.3 \text { of the drums shall be filled with } \\
\text { simulated sludge. }\end{array}$ & & & $\mathrm{X}$ & & & & $\begin{array}{l}35 \text { drums were filled } \\
\text { with sludge. }\end{array}$ \\
\hline $\begin{array}{l}33 \text { of the drums shall be filled with } \\
2,000 \text { - lb strength concrete. }\end{array}$ & & $\mathrm{X}$ & & & & & \\
\hline $\begin{array}{l}110 \text { drums filled with paper, wood, and } \\
\text { cloth. }\end{array}$ & & $X$ & & & & & \\
\hline
\end{tabular}


Table A-1. continued.

\begin{tabular}{|c|c|c|c|c|c|c|c|}
\hline Specification & EH & $\mathrm{CO}$ & VA & AL & EX & $\mathrm{N} / \mathrm{U}$ & Comments \\
\hline 22 drums filled with scrap metal. & & $\mathrm{X}$ & & & & & \\
\hline $\begin{array}{l}22 \text { drums filled with a mixture of } \\
\text { material. }\end{array}$ & & & $\mathrm{X}$ & & & & $\begin{array}{l}23 \text { drums filled with } \\
\text { a random mixture of } \\
\text { material. }\end{array}$ \\
\hline $\begin{array}{l}\text { After filling, the boxes and drums may } \\
\text { be banded to help stabilize them during } \\
\text { placement. }\end{array}$ & & $\mathbf{X}$ & & & & & \\
\hline $\begin{array}{l}\text { Alter placement and before burial, all } \\
\text { bands shall be cut. }\end{array}$ & & & $\mathrm{X}$ & & & & $\begin{array}{l}\text { Most bands were } \\
\text { cut, but some could } \\
\text { not be reached } \\
\text { safely. }\end{array}$ \\
\hline $\begin{array}{l}\text { After the containers are in place they } \\
\text { shall be saturated with water to help } \\
\text { deteriorate the cardboard containers. }\end{array}$ & & $\mathrm{X}$ & & & & & \\
\hline $\begin{array}{l}\text { The area shali be covered with clean fill } \\
\text { dirt. }\end{array}$ & & $X$ & & & & & \\
\hline $\begin{array}{l}\text { The stacked boxes and drums shall have } \\
\text { an approximate cover of } 4 \mathrm{ft} \text { of soil. }\end{array}$ & & $\mathrm{X}$ & & & & & \\
\hline $\begin{array}{l}\text { Soil cover shall be graded level and } \\
\text { compacted to at least } 90 \% \text { maximum } \\
\text { density. }\end{array}$ & & $\mathrm{X}$ & & & & & \\
\hline $\begin{array}{l}\text { The boundary of the cold test pit and } \\
\text { cells shall be well marked at the surface. }\end{array}$ & & $\mathrm{X}$ & & & & & \\
\hline $\begin{array}{l}\text { The debris and soil removed from the } \\
\text { cells will be deposited in subcontractor } \\
\text { provided } 4 \times 4 \times 8 \text {-ft storage boxes. }\end{array}$ & & $\mathrm{X}$ & & & & & \\
\hline $\begin{array}{l}\text { A funneling system shall also be } \\
\text { provided to help focus simulated waste } \\
\text { into the storage containers. }\end{array}$ & & $\mathrm{X}$ & & & & & \\
\hline $\begin{array}{l}\text { No more than two funnels and storage } \\
\text { containers may be used at one time } \\
\text { during the retrieval effort. }\end{array}$ & & $\mathrm{X}$ & & & & & $\begin{array}{l}\text { One funnel and one } \\
\text { transport box were } \\
\text { used during the field } \\
\text { demonstration. }\end{array}$ \\
\hline $\begin{array}{l}\text { All waste retrieved from the pit must be } \\
\text { sized to fit in a storage box. }\end{array}$ & & $X$ & & & & & \\
\hline $\begin{array}{l}\text { Debris shall be sized at the digface to fit } \\
\text { inside a storage box and require no } \\
\text { human contact. }\end{array}$ & & $\mathrm{X}$ & & & & & \\
\hline
\end{tabular}


Table A-1. continued.

\begin{tabular}{|c|c|c|c|c|c|c|c|}
\hline Specification & $\mathrm{EH}$ & $\mathrm{CO}$ & VA & $\mathrm{Al}$ & EX & $N / U$ & Comments \\
\hline $\begin{array}{l}\text { After a box is filled the subcontractor } \\
\text { shall remove the box and place an empty } \\
\text { one under the funnel. }\end{array}$ & & $\mathrm{X}$ & & & & & \\
\hline $\begin{array}{l}\text { The filled box shall be dumped } \\
\text { elsewhere. }\end{array}$ & & $X$ & & & & & \\
\hline $\begin{array}{l}\text { The subcontractor shall supply as many } \\
\text { boxes as required to keep a constant } \\
\text { supply of empty boxes available for } \\
\text { placing excavated debris in. }\end{array}$ & & $X$ & & & & & \\
\hline $\begin{array}{l}\text { The storage boxes may be constructed of } \\
\text { wood, metal, or other material the } \\
\text { subcontractor deems appropriate for the } \\
\text { application, but the boxes must be sturdy } \\
\text { enough to withstand the intended duty } \\
\text { (i.e., dumping, supporting loads of } 2,000 \\
\text { to } 5,000 \mathrm{lb} \text {, and transporting the } \\
\text { simulated waste). }\end{array}$ & & $X$ & & & & & \\
\hline $\begin{array}{l}\text { The subcontractor shall supply } \\
\text { equipment to handle the boxes, and it is } \\
\text { his choice as how to best accomplish this } \\
\text { task. }\end{array}$ & & $X$ & & & & & \\
\hline $\begin{array}{l}\text { The funnel and boxes may be located as } \\
\text { close as practicable to the digface and in } \\
\text { the proximity of the excavating } \\
\text { equipment as the subcontractor } \\
\text { determines appropriate. }\end{array}$ & & $X$ & & & & & \\
\hline
\end{tabular}

KEY: HH-Enhancement: Capability exceeds the stated functional or design requirement.

CO-Conforms: Meets the functional or design requirement.

VA-Variation: $\quad$ Meets the requirements but with minor variations.

Al.-Alternate: Does not meel the stated functionat or design requirement. However, an alternative that provides the equivalent function is offered.

E:X.Fxception: Unable to comply with this item of this specification; therefore, this feature is not offered. State reason for noncompliance.

N/U-Noted and Acknowledgment of items that are instructions, guidelines or background information included in Understood: Statement of Work for clarification purposes. 


\section{Appendix B}

\section{Equipment Production Matrix}




\section{Appendix B}

\section{Equipment Production Matrix}

\section{RETRIEVAL DEMONSTRATION PRODUCTION RATES}

Table B-1. Production matrix.

\begin{tabular}{|c|c|c|c|c|c|c|c|c|c|}
\hline Datc & $\begin{array}{l}\text { Pass } \\
\text { no. }\end{array}$ & Position & Cells $^{\mathrm{a}}$ & Equipment & $\begin{array}{l}\text { Cuhic yards } \\
\text { removed }\end{array}$ & $\begin{array}{l}\text { Time } \\
\text { equipment } \\
\text { used }\end{array}$ & $\begin{array}{c}\text { Cubic } \\
\text { yards } \\
\text { per } \\
\text { hour }\end{array}$ & $\begin{array}{l}\text { Cumulative } \\
\text { cuhic yards }\end{array}$ & Comments \\
\hline lune 7 & 1 & belowgrade & $\begin{array}{l}\text { random } \\
(100) \\
\text { berm } \\
(38) \\
\text { stacked } \\
(7)\end{array}$ & $\begin{array}{l}325 \text { excavalor } \\
\text { with thumb }\end{array}$ & 145 & $3: 45$ & 39 & 145 & $\begin{array}{l}\text { About } 30 \\
\text { minutes of } \\
\text { total time } \\
\text { was used to } \\
\text { size large } \\
\text { objects after } \\
\text { removal } \\
\text { from pit. }\end{array}$ \\
\hline June 8 & 1 & belowgrade & $\begin{array}{l}\text { stacked } \\
(15)\end{array}$ & $\begin{array}{l}\text { ITC28 with } \\
\text { grip and grab }\end{array}$ & 15 & $: 30$ & 30 & 160 & $\begin{array}{l}\text { This tool } \\
\text { used for } \\
\text { loose debris } \\
\text { and soil only }\end{array}$ \\
\hline June 9 & 1.2 & helowgrade & $\begin{array}{l}\text { stacked } \\
(130)\end{array}$ & $\begin{array}{l}325 \text { excavator } \\
\text { with thumb }\end{array}$ & 130 & $2: 00$ & 65 & 290 & $\begin{array}{l}325 \text { worked } \\
\text { faster in } \\
\text { stacked } \\
\text { debris } \\
\text { because } \\
\text { there were } \\
\text { no large } \\
\text { objects and } \\
\text { no cable. }\end{array}$ \\
\hline June 9 & 2 & helnwgrade & $\begin{array}{l}\text { stacked } \\
(35)\end{array}$ & $\begin{array}{l}935 \text { track } \\
\text { loader with } \\
\text { multi-purpose } \\
\text { huckel }\end{array}$ & 35 & $1: 00$ & 35 & 325 & $\begin{array}{l}935 \text { worked } \\
\text { well with } \\
\text { Joose debris } \\
\text { but would } \\
\text { not be } \\
\text { effective with } \\
\text { in situ } \\
\text { materials. }\end{array}$ \\
\hline June 9 & 2 & belowgrade & $\begin{array}{l}\text { stacked } \\
(30) \\
\text { herm } \\
(10)\end{array}$ & $\begin{array}{l}\text { ITC } 28 \text { with } \\
\text { grip and grab }\end{array}$ & 40 & $1: 00$ & 40 & 365 & $\begin{array}{l}\text { Grip and } \\
\text { grab ok for } \\
\text { loose soil } \\
\text { and debris } \\
\text { but not } \\
\text { feasible for } \\
\text { removal of in } \\
\text { situ material. }\end{array}$ \\
\hline
\end{tabular}


Table B-1. continued.

\begin{tabular}{|c|c|c|c|c|c|c|c|c|c|}
\hline Date & $\begin{array}{l}\text { Pass } \\
\text { no. }\end{array}$ & Posilion & Ceclls & Fiquipment & $\begin{array}{l}\text { Cuhic yarda } \\
\text { removed }\end{array}$ & $\begin{array}{l}\text { Time } \\
\text { equipment } \\
\text { used }\end{array}$ & $\begin{array}{l}\text { Cubic } \\
\text { yards } \\
\text { per } \\
\text { hour }\end{array}$ & $\begin{array}{l}\text { Cumulative } \\
\text { cubic yards }\end{array}$ & Commenis \\
\hline June 9 & 2 & helowgrade & $\begin{array}{l}\text { stacked } \\
(55) \\
\text { herm } \\
(30) \\
\text { random } \\
(115)\end{array}$ & $\begin{array}{l}\text { EL. } 2(0) B \\
\text { excavator with } \\
\text { front shovel }\end{array}$ & 200 & $4: 00$ & 50 & 565 & $\begin{array}{l}\text { Fronl showel } \\
\text { proved in be } \\
\text { an effective } \\
\text { tool for } \\
\text { loose and in } \\
\text { situ } \\
\text { debris-not } \\
\text { sultable for } \\
\text { large objects. }\end{array}$ \\
\hline June 9 & 2 & belowgrade & $\begin{array}{l}\text { random } \\
(40)\end{array}$ & $\begin{array}{l}325 \text { cxcavator } \\
\text { with thumb }\end{array}$ & 40 & $1: 00$ & 40 & 605 & $\begin{array}{l}325 \text { used in } \\
\text { remove large } \\
\text { objects from } \\
\text { pil-235 with } \\
\text { shear used io } \\
\text { size large } \\
\text { objects. }\end{array}$ \\
\hline June 10 & 3 & ahovegrade & $\begin{array}{l}\text { slacked } \\
(1.38) \\
\text { herm } \\
(38) \\
\text { random } \\
(44)\end{array}$ & $\begin{array}{l}325 \text { excavator } \\
\text { with thumb }\end{array}$ & 220 & $4: 15$ & 52 & 825 & $\begin{array}{l}\text { No large } \\
\text { objects or } \\
\text { cable were } \\
\text { encountered. }\end{array}$ \\
\hline June 15 & 4 & belowgrade & $\begin{array}{l}\text { random } \\
(166)\end{array}$ & $\begin{array}{l}325 \text { excavator } \\
\text { with thumb }\end{array}$ & 166 & $3: 15$ & 51 & 991 & $\begin{array}{l}\text { Several } \\
\text { pipes, beams, } \\
\text { and cable } \\
\text { were } \\
\text { removed and } \\
\text { sized as well } \\
\text { as the pickup } \\
\text { truck bed. }\end{array}$ \\
\hline June 15 & 4 & ahovegrade & $\begin{array}{l}\text { berm } \\
(30) \\
\text { slacked } \\
(79)\end{array}$ & $\begin{array}{l}325 \text { excavator } \\
\text { with thumb }\end{array}$ & 109 & $2: 15$ & 48 & 1100 & $\begin{array}{l}\text { No large } \\
\text { objects or } \\
\text { cable were } \\
\text { enrountered. }\end{array}$ \\
\hline
\end{tabular}


11
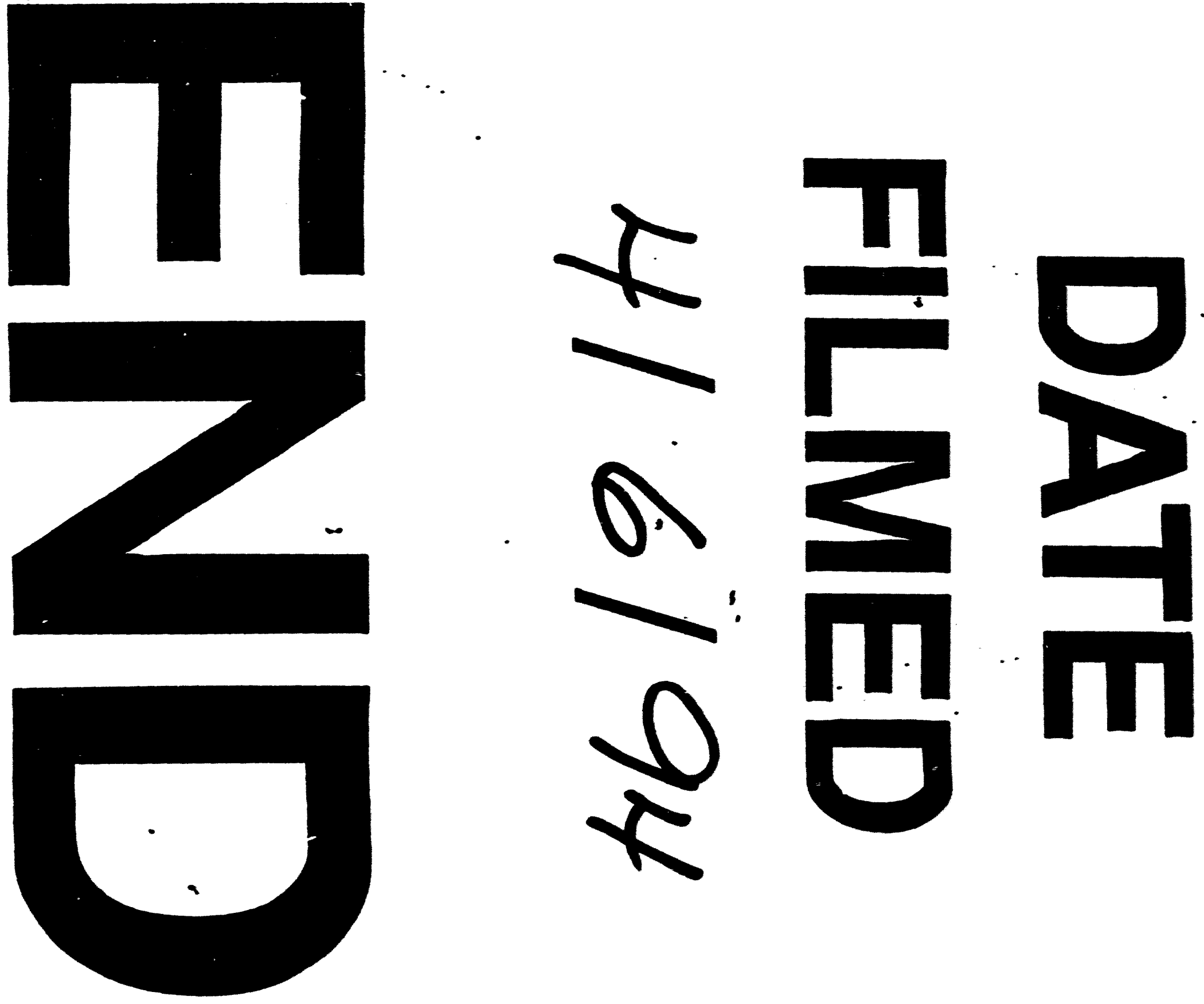


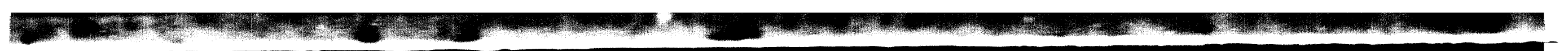

